\title{
AN AREA-WIDE \\ REAL-TIME \\ DATABASE FOR \\ THE EURO AREA
}

by Domenico Giannone,

Jérôme Henry,

Magdalena Lalik

and Michele Modugno 
EUROSYSTEM

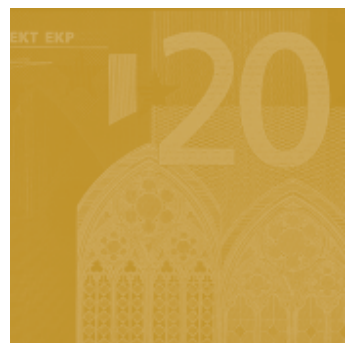

\title{
WORKING PAPER SERIES
}

NO II45 I JANUARY 2010

\author{
by Domenico Giannone², Jérôme Henry³, \\ Magdalena Lalik ${ }^{4}$ and Michele Modugno ${ }^{5}$
}

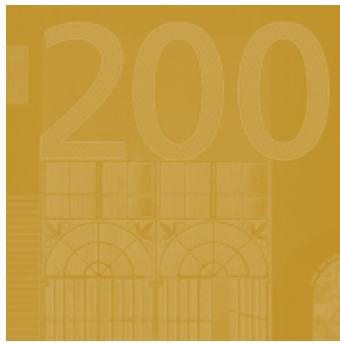

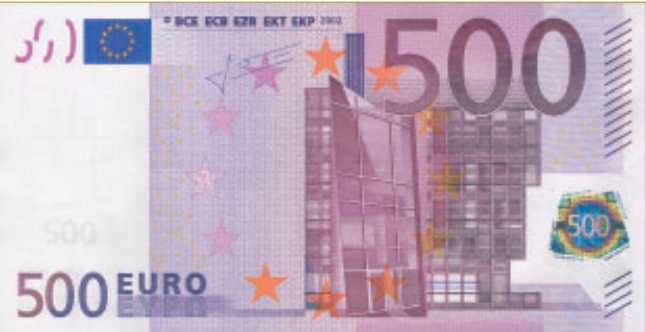

In 2010 all ECB publications feature a motif taken from the $€ 500$ banknote.

\section{AN AREA-WIDE REAL-TIME DATABASE FOR THE EURO AREA'}
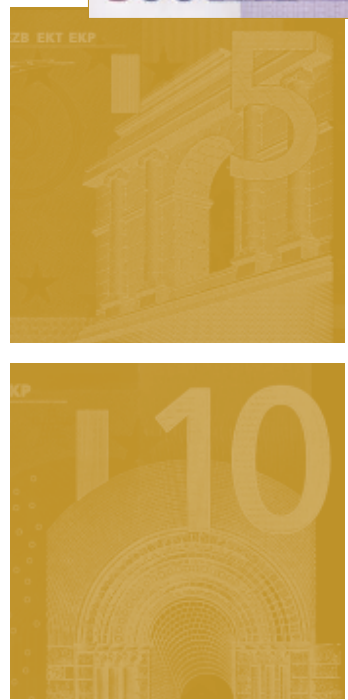

I The project was initiated by L. Reichlin and conducted within the Euro Area Business Cycle network (EABCN), supported by the CEPR and by participating European central banks. Special thanks go to D. Croushore and A. Orphanides who also greatly helped at various stages of the project. The project benefited from comments by the EABCN Steering Committee and by participants in the EABCN Workshop at Bank of Belgium, June 2005, in the CIRANO / Bank of Canada Workshop on real-time data, October 2005, and in the Link European meeting at UN Geneva, October 2006 as well as from input by M. Ciccarelli. Comments and suggestions by K. H. Dieden, $\mathrm{H}-1$. Klöckers and the editors are also gratefully acknowledged. The opinions expressed in this paper are those of the authors and do not necessarily reflect those of the European Central Bank. Database users are kindly requested to refer to the current paper in their related work and publications.

2 Université Libre de Bruxelles. ECARES CP 144, B-1050 Bruxelles, Belgium; e-mail: dgiannon@ulb.ac.be Was with ECB-DG-Research at the time the paper was completed. 3 European Central Bank, DG-Economics, Kaiserstrasse 29, 603II Frankfurt am Main, Germany; e-mail: jerome.henry@ecb.europa.eu 4 European Central Bank, DG-Statistics. Kaiserstrasse 29, 603II Frankfurt am Main, Germany; e-mail: magdalena.lalik@ecb.europa.eu 5 European Central Bank, DG-Research. Kaiserstrasse 29, 603II Frankfurt am Main, Germany; e-mail: michele.modugno@ecb.europa.eu 


\section{(C) European Central Bank, 2010}

\section{Address}

Kaiserstrasse 29

60311 Frankfurt am Main, Germany

Postal address

Postfach 160319

60066 Frankfurt am Main, Germany

\section{Telephone}

+496913440

\section{Website}

http://www.ecb.europa.eu

\section{Fax}

+496913446000

All rights reserved.

Any reproduction, publication and reprint in the form of a different publication, whether printed or produced electronically, in whole or in part, is permitted only with the explicit written authorisation of the ECB or the author(s).

The views expressed in this paper do not necessarily reflect those of the European Central Bank.

Information on all of the working papers published in the ECB's Working Paper Series can be found on the ECB's website, http://www.ecb.europa.eu/pub/scientific/ wps/date/html/index.en.html

ISSN 1725-2806 (online) 


\section{CONTENTS}

Abstract

Non-technical summary

1 Introduction: The Real-Time DataBase EABCN project

2 An overview of the database content and structure

3 Statistics on data revisions

4 Comparison with the United States and Japan

5 Key euro area macroeconomic ratios

6 NAIRU computations in real time

7 Summary and conclusions

Bibliography

Tables and figures

Annexes 


\begin{abstract}
This paper describes how we constructed a real-time database for the euro area covering more than 200 series regularly published in the European Central Bank Monthly Bulletin, as made available ahead of publication to the Governing Council members before their first meeting of the month. We describe the database in details and study the properties of the euro area real-time data flow and data revisions, also providing comparisons with the United States and Japan. We finally illustrate how such revisions can contribute to the uncertainty surrounding key macroeconomic ratios and the NAIRU.
\end{abstract}

JEL Classification: C01, C82, E24, E58.

Keywords: real-time, euro area, revisions, database. 


\section{Non-technical Summary}

Monetary policy decisions are taken on the basis of a large set of economic data. However, available data are often incomplete as they are released at differing points in times, with different publication lags and are, to a large extent, subsequently revised. Recent research has emphasised that the resulting data uncertainty can be large and have a bearing on the decisions made, as well as affect the assessment of their relevance. It is therefore key to reconstruct the historical environment of economic decisions at the time they were made rather than using the data as they become available some years later, as stressed by Orphanides (2001). For this purpose, it is necessary to have at hand all data vintages as they were published in real time, the so-called "real-time data" that reflect the economic situation at a given point in time when models are estimated or policy decisions made.

The pioneering project in this field started at the Philadelphia Fed. The data, for the US, were made available through the website of the Philadelphia Fed. On this basis, research has been conducted, both on methodological issues and on economic policy aspects, such as the ex post interpretation of policy actions. This dataset, however, is limited to a few series, moreover covering only the US. Only in the last few years, have efforts been accomplished to archive more series, covering different aspects of the economy (at the St Louis Fed), and data for other countries. Relevant projects have been conducted at the OECD for several countries; at the Bundesbank for Germany; at the Office for National Statistics and Bank of England for the UK. Eurostat has also plans to make available a comprehensive database covering all Principal European Economic Indicators, with daily snapshots of data. Also at the ECB, similar work has been conducted, with analyses focusing on the data revision process.

The combination of stimulating results from the literature on the US especially - as extensively reported in the survey by Croushore (2006) - with the related absence of such dataset for the euro area was the main motivation for the Euro Area Business Cycle Network (website www.eaben.org) to launch the Real-Time DataBase (RTDB) project which eventually led to the database now documented. With a view to stimulating research on realtime analysis applied to the euro area, it was important to involve the ECB and Eurosystem national central banks as well as researchers. ECB staff from DG Statistics, Research and Economics worked jointly on the project, in consultation with EABCN (academic and central banking) members, thereby combining the expertise and perspective of various interested users. The area-wide RTDB for the euro area has been followed by a multi-country database (produced by Eurosystem National Central Banks), also available on the EABCN website. 
We present in detail in this paper how we constructed the area-wide RTDB for the euro area, i.e. a collection of (mostly euro area) series regularly published in the ECB Monthly Bulletin for each month since the euro started. The data therefore represents a historical record of the summary information supplied to the public each month via the Monthly Bulletin. Just ahead of this latter publication, the ECB Governing Council receives the data in time for its first meeting of any given month. This was where in most cases, policy discussions were held and related actions considered. The Governing Council obviously considers a much wider array of material and background documentation when making decisions, than only these data per se.

This dataset, as the ECB Monthly Bulletin, has a very extensive coverage (some 230 series for the euro area as a whole, including some survey data) since 2001 and is regularly updated, all aspects which should be of particular interest to researchers. Resulting successive versions of the datasets have been posted on the $\mathrm{EABCN}$ website; the dissemination to the public at large will be operated via the ECB Statistical Data Warehouse (http://sdw.ecb.europa.eu/). The paper provides an overview of the database coverage, content and its technical organisation - along with annexes documenting the database in fuller detail.

We also present a variety of results illustrating the potential use of this "real-time" dataset. We compute revision statistics for the main indicators listed in the ECB Monthly Bulletin "overview table". Results for all series are available in appendices. We study the real-time data revision and data-flow processes in the euro area, also in comparison with the US and Japan. Revisions for the euro area appear, especially for real variables, as relatively limited.

At the same time, revisions to euro area macroeconomic data can be substantial enough to affect the assessment of the macroeconomic situation in the euro area at a given point in time. For instance, GDP composition or Industrial Production indices can experience important changes over time. Also the unemployment rate or the saving ratio are typically subject to sizeable revisions, albeit mostly affecting the level rather than the trends in the reviewed series. Labour productivity trends or the degree of openness seem to be less affected than other key ratios such as terms of trade or propensities to consume or invest out of GDP.

In order to further illustrate the impact of real-time effects and of revisions to data on quantitative macroeconomic analysis, we also provide real-time and pseudo-real time NAIRU estimates for the euro area on the basis of this euro area-wide database. The computations show that the uncertainty relating to data revisions, albeit sizeable, would in the case at hand still be dominated by that arising from the estimation of the parameters. 


\section{Introduction: The Real-Time DataBase EABCN project}

Monetary policy decisions are taken on the basis of a large set of economic data. However, available data are often incomplete as they are released at differing points in times, with different publication lags and are, to a large extent, subsequently revised. Recent research has emphasised that the resulting data uncertainty can be large for certain indicators and can have a bearing on the decisions made, as well as affect the assessment of their relevance. It is therefore key to be in a position to reconstruct the historical environment of economic decisions at the time they were made by private agents and policy-makers rather than using the data as they become available some years later, as stressed in particular by Orphanides (2001). For this purpose, it is necessary to have the information in the form of all the different vintages of data as they were published in real time, the so-called "real-time data" that reflect the economic situation at a given point in time when models are estimated or policy decisions made.

Unfortunately, real-time vintages are generally readily available for only few key variables and typically do not cover a long sample, reflecting the only recent attention paid to such issues by most institutions. The pioneering and most inspiring project in this field started at the Philadelphia Fed. The data, for the US economy, were made available to the public through the website of the Philadelphia Fed ${ }^{1}$. On this basis, research has been conducted, both on methodological issues, such as the robustness of different tools to data revisions (e.g., Croushore and Stark, 2005; Orphanides and Van Norden, 2002), ${ }^{2}$ and on economic policy aspects, such as the ex post interpretation of policy actions (e.g., Orphanides, 2001). This information, however, is still limited to few data series, moreover covering only US variables. Only in the last few years, have efforts been accomplished to archive a larger number of series, covering different aspects of the economy (at the St Louis $\mathrm{Fed}^{3}$ ), and data for countries other than the US. Relevant projects have been conducted at the $\mathrm{OECD}^{4}$ for several countries; at the Bundesbank for the German economy ${ }^{5}$; at the Office for National Statistics ${ }^{6}$ and Bank of England ${ }^{7}$ for the UK. Eurostat has also plans to make publicly available a comprehensive database covering all Principal European Economic Indicators, comprising daily snapshots of

\footnotetext{
${ }^{1}$ The project and its results are documented in Croushore and Stark (2001).

${ }^{2}$ In particular the estimation and evaluation of forecasting models would be affected by the use of real-time data (as known already from Fair and Shiller, 1990, or Swanson, 1996).

${ }^{3}$ See Anderson (2006). The euro area-wide RTDB work we conducted also aimed at such a broader coverage.

${ }^{4}$ See OECD (2003).

${ }^{5}$ Data are available at http://www.bundesbank.de/vfz/vfz_echtzeitdaten.en.php.

${ }^{6}$ See Jenkinson (2004).

${ }^{7}$ See Castle and Ellis (2002).
} 
data (see Ladiray et al., 2008). Also at the ECB, similar collection work has been conducted, with analyses focusing on the data revision process. ${ }^{8}$

The combination of stimulating results from the literature on the US especially - as extensively reported in the survey by Croushore (2006) - with the related absence of such dataset for the euro area was the main motivation for the Euro Area Business Cycle Network (see its website www.eabcn.org) to launch the Real-Time DataBase (RTDB) project which eventually led to the database now documented. With a view to stimulating research on realtime analysis applied to the euro area as a whole and the comprised countries, it was important to involve the ECB and Eurosystem national central banks as well as the research community in the project. ECB staff from DG Statistics, Research and Economics worked jointly on the project, in consultation with EABCN (academic and central banking) members, thereby combining the expertise and perspective of various interested users. The area-wide RTDB for the euro area has been followed by a corresponding multi-country leg of the project (conducted in turn by Eurosystem National Central Banks), the output of which has lately also become available on the EABCN website.

In this paper, we present in detail how we constructed the area-wide RTDB for the euro area, i.e. a collection of (mostly euro area) series regularly published in the ECB Monthly Bulletin for each month since the euro started. The data therefore represents a historical record of the summary information supplied to the public each month via the Monthly Bulletin. Just ahead of this latter publication, the ECB Governing Council receives the data in time for its first meeting of any given month. This was where in most cases, policy discussions were held and related actions considered. ${ }^{9}$ The Governing Council obviously considers a much wider array of material and background documentation when making decisions, than only these data per se.

This dataset, compiling data from the ECB Monthly Bulletin, has a very extensive coverage (some 230 series for the euro area as a whole, including some survey data) since 2001 and is regularly updated, all aspects which should be of particular interest to researchers. ${ }^{10}$ Even

\footnotetext{
${ }^{8}$ See Branchi et al. (2007), a related study which focuses on series for main aggregates and on the underlying statistical revision process leading to the latest vintage available. They also provide results on country data. We in turn provide and analyse data on breakdowns, information on the revision process shortly after the first release of data (i.e. when policy-relevant) as well as conduct a number of illustrative albeit simple economic analyses.

${ }^{9}$ Until November 2001 the Governing Council had been indeed discussing the policy issues on both meetings, however, decisions made to change interest rates outside the first meeting were exceptional, as e.g. on 17 September 2001.

${ }^{10}$ Many "real-time" database constructors indeed stop after to the one-off step of gathering past vintages, without updating the data regularly afterwards - a costly task for which specific logistics and routines had to be set up.
} 
though the sample covered to date remains relatively short - US data vintages had e.g. been collected since 1965 at the Philadelphia Fed - reflecting the still recent start of the euro area, the regular updates imply that the available sample continuously increases. Resulting successive versions of the datasets have been posted on the EABCN website ${ }^{11}$; the dissemination to the public at large will be operated via the ECB Statistical Data Warehouse (http://sdw.ecb.europa.eu/). ${ }^{12}$

The paper is organized as follows. Section 2 provides an overview of the database coverage, content and its technical organisation. Section 3 shows revision statistics, focusing on main indicators, such as reported in the Monthly Bulletin "overview table". Additional results for all series in the database are also made available in appendices to the paper. A comparison with US and Japan comparable series is undertaken in Section 4. Section 5 documents the sensitivity of key macroeconomic ratios to data revisions. A similar illustrative exercise is conducted in Section 6, involving NAIRU computations. Section 7 concludes.

\section{An overview of the database content and structure}

The area-wide RTDB comprises about 230 indicators altogether. Vintages for most variables start in January 2001; for this paper data has been used until the June 2009 edition of the ECB Monthly Bulletin. Moreover, for a selected subset of 38 key selected series (those mostly relevant for economic and econometric analysis), vintages have been included as of October 1999 - data before 2001 were not readily available on a harmonised e-archive basis, hence this limited extension focusing on key series. The time-span covered by these series goes generally back to the mid 1990s, but can extend to 35 years in some cases (e.g. for US series).

The area-wide RTDB contains data as published in the ECB Monthly Bulletin. The dataset is therefore based on a "snapshot" approach, i.e. it represents the state of the information as available at the moment when the snapshot was taken. The idea is to provide database users (and Monthly Bulletin readers) with the same information as available for the meeting of the Governing Council which is held just before the publication of a given Monthly Bulletin issue. This timing aspect plays an important role in the process of the Monthly Bulletin production itself, since it is crucial to assure consistency across series eventually published

\footnotetext{
${ }^{11}$ The data has already been fruitfully used for research purposes (e.g. Marcellino and Musso, 2009, on output gap robustness, and Giannone et al., 2009, on the real-time predictive power of surveys for GDP, and Kaufman and Kugler, 2009, on real-time forecasts of inflation). Database users are kindly requested to refer to the current paper in their related work and publications.

12 The presentation of the dataset in SDW, albeit different due to technical reasons, is consistent with the description provided in what follows. The Explanation pages are available in the SDW with detailed information on how to best utilise its functionalities.
} 
that were reported to the Governing Council beforehand. In statistical jargon, the process of creating such a snapshot is called "freezing" and the day when it takes place is referred to as a "cut-off date" for the information used. As a rule, the cut-off date for the Monthly Bulletin data is scheduled for the day before the first Governing Council meeting in a month. The list of all cut-off dates as of January 2001 can be found in Annex 1.

Data have been grouped by vintages and frequency. Files ${ }^{13}$ are therefore available for each frequency used (monthly, quarterly and annual) comprising time-series for all variables for each vintage of the Monthly Bulletin. Given the size of the dataset, this organisation appeared as the easiest to facilitate the construction of the dataset and its regular update. The detailed tables below report for each frequency the content of the various files in terms of main blocks of series included in each available vintage. In line with the presentation followed in the ECB Monthly Bulletin, for many broad indicators not only the total aggregate figure is reported but also a corresponding breakdown in sub-components. For instance, for the industrial production index, corresponding results for seven sub-sectors are provided. Similarly details are provided on the HICP sub-items or on GDP components, in order to allow for deeper analyses of both revision patterns and real-time econometrics. Details on all breakdowns reported can readily be found in the ECB Monthly Bulletin regular methodological notes.

For the smaller subset covering monthly releases since late 1999 (available on the EABCN site), the data was made accessible in turn on the basis of an organisation by variables. For each variable, an excel file comprising all vintages is available in which each column refers to a specific vintage of data. The name of the files is based, when feasible, on the codes used in the ECB Area Wide Model (see Annex 2 for the list of key series).

The definition of the data included in the RTDB follows a "policy" concept. Since it was not possible to collect all of the series based on exactly the same methodological properties over the entire period of interest, it was decided to collect the data according to the concepts as they were presented in the Monthly Bulletin in a given month. For instance, in the course of 2005 and 2006, ESA95 national accounts data underwent major changes as a result of the introduction of chain-linking of annual and quarterly series at constant prices, the new treatment of FISIM and benchmark revisions. Consequently, applying the "policy" concept,

\footnotetext{
${ }^{13}$ The CSV files have been published on the EABCN website until November 2009. Since the dissemination of RTDB data into the ECB Statistical Data Warehouse, they can be downloaded from the corresponding SDW "Explanation" pages.
} 
the vintages for example GDP in real terms consists of constant prices data up to November 2005 and chain-linked series as of December 2005. Also in the period 2005-06, euro area employment statistics were relatively unstable owing to substantial revisions on the country level. Such changes of course need to be documented; details about the precise definition and the tracking of the variables included in the dataset are therefore reported in Annex $3^{14}$.

Another, very specific, issue pertaining to the area-wide RTDB is that of the relevant definition of the euro area. Following the successive enlargements of the euro zone, the aggregated euro area official statistics have used different definitions for the euro area as an entity. Alternative geographic areas have been introduced that are all called "euro area", but in fact with differing country coverage. Two concepts of euro area country composition are employed: the fixed composition - using the same group of countries throughout all periods and the changing composition - using the euro area composition at the time to which the statistics relate. In the latter, data prior to 2001 refer to the Euro 11, i.e. the following $11 \mathrm{EU}$ Member States: Belgium, Germany, Ireland, Spain, France, Italy, Luxembourg, the Netherlands, Austria, Portugal and Finland. Data from 2001 to 2006 refer to the Euro 12, i.e. the Euro 11 plus Greece. Data for 2007 refer to the Euro 13, i.e. the Euro 12 plus Slovenia, data for 2008 refer to the Euro 15, i.e. the Euro 13 plus Cyprus and Malta, whereas data as of 2009 refer to the Euro 16, i.e. the Euro 15 plus Slovakia. ${ }^{15}$

It is finally worth recalling, that even though the ECB publishes all of the underlying data in its regular statistical publications, it is not the actual data provider for many of them. The source information is therefore mentioned on top of each data block to indicate the primary data source, in many cases the European Commission (Eurostat).

\section{Statistics on data revisions}

For illustration purposes, focusing on series for which international comparisons are available from the dataset, Figures 1 report all available vintages for four time-series of key indicators, GDP, Industrial Production, Unemployment Rate and HICP (Harmonized Index of Consumer Prices). The plotted series also correspond to the variables for which revisions computed were most substantial among the series reported in the Monthly Bulletin "overview table". A first observation from this quite limited set of variables is that real variables get more often and

\footnotetext{
${ }^{14}$ The Annex is regularly updated and its latest version can be downloaded from the corresponding SDW "Explanation" pages.

${ }^{15}$ Official series from Eurostat that are included in this database are official euro area series; Eurostat makes use of the country statistical information as available to derive an aggregation.
} 
more sizeably revised than the HICP. Revisions are nonetheless somewhat limited to overall GDP, while industrial production and even more the unemployment rate seem to be subject to higher and more frequent revisions.

In order to assess more precisely the impact of these revisions on the various series included in the database, revision statistics can be computed for all series included - therefore at monthly, quarterly and annual frequencies. Given that the monthly vintages contain variables observed with different frequencies, a special notation has to be employed for that purpose. We denote by $Y(t \mid t+i)$ the variables of interest, where $\mathrm{x}$ is the quarter (month) to which the quarterly (monthly) observation refers; $i$ is the number of months after the last month in the reference quarter (month). For instance, $Y(2001 Q 3 \mid 2001 Q 3+2)$ indicates the value of the quarterly series Y for the third quarter 2001 in the November 2001 Monthly Bulletin, while $Y($ Feb2001I Feb2001+2) indicates the value of the monthly series Y for February 2001 in the April 2001 Monthly Bulletin. ${ }^{16}$ One standard revision statistics we have reported in tables is the so-called "revision error", i.e. $Y(t \mid t+i)-Y(t \mid t+24)$ for $i=2,3, \ldots, 24$; $t=\operatorname{Jan} 00, \ldots, J u n 09$ for monthly data and $t=00 Q 1, \ldots, 07 Q 3$ for quarterly data. This represent the gap between a given vintage estimate and the corresponding "final" estimate, i.e. the opposite of the revision.

The choice of a final date for computing revisions is neither a trivial nor a neutral step. The revision process affecting some data, e.g. National Accounts, is indeed a never-ending process and there are e.g. substantial revisions even after two years, taking into account also the so-called benchmark revisions. This long-lasting process is strikingly illustrated in Figure 2 which plots GDP growth rate for the fourth quarter of 2001 as reported in different issues of the ECB Monthly Bulletin. This period roughly coincides with an international slowdown, and the first releases then pointed to a decline in euro area economic activity, at the time the largest experienced since the inception of the euro. Subsequent revisions however provided a

\footnotetext{
${ }^{16}$ In line with the definition employed in the above Tables, if the data has quarterly frequency the Publication lag is defined as the number of months between the last month in the reference quarter and the month in which it is published for the first time in the Monthly Bulletin. For monthly data, the Publication lag is defined as the number of months between the reference month and the month in which is published in the Monthly Bulletin.
} 
more positive assessment of business conditions in the euro area then prevailing; most recent figures now even indicating an increase rather than a decline in GDP. ${ }^{17}$

Bearing such revision features in mind, the choice made of computing revisions with respect to the issue of the ECB Monthly Bulletin two years later is somewhat arbitrary but can be equally motivated by the following reasons. First, it is interesting to analyse how a given observation is likely to evolve following a standard, if any, revision pattern along a policyrelevant horizon. Second, the number of vintages available is small, hence using a longer horizon would produce an analysis based only on few data points (as long as the focus is on quarterly data). Third, even though there is hardly a clear definition of what "final" data are, in particular for National Accounts, a two-year period may appear as a good proxy to being closer to that "final" measure - always capturing inter alia the first update of annual data. Finally, work on forecast ex-post accuracy when faced with the same issue of defining the "final" relevant measure tends to make use of similarly relatively short horizons (using typically the first release of the following year), as forecast errors would tend for all practical purposes to be reviewed ex post after a relatively short span of time rather than a decade later.

The revision analysis is conducted, for all series, on the sample between the last observation available in the first (January 2001) vintage to the last available observation comprised in the June 2007 vintage, i.e. exactly 24 months before the last vintage we use. This implies that for each series, revision statistics at all horizons have been computed, broadly speaking, over the period end-2000 to end-2006. This approach ensures that revisions for the various horizons (up to 24 months) considered are analysed on a sample roughly common to all series and also track the whole history of revisions (up to 24 months later) to the analysed observations.

The first releases of any given observation are represented on all charts by crosses. The latter also help to visualise for each observation the magnitude of revisions across subsequent vintages. At the same time, earlier revisions, i.e. to observations located before the first cross, are not accounted for in the reported statistics. This may not be neutral to the results, as some of the earlier revisions (not included in the sample used for computing revisions) can be of an opposite sign - as can be seen e.g. for unemployment.

For all series, we report the mean and the standard deviations of the data revisions. For reference, we also report the mean and the standard deviation of the series itself, as measured

\footnotetext{
${ }^{17}$ See Branchi et al. (2007) for a review of sources of revisions to National Account data. Revisions at the euro area level reflect the incorporation of new information combined with changes in methods.
} 
in the last available vintage corresponding to the Monthly Bulletin of June 2009. This provides useful information, as the magnitude of the revisions to a given series may well relate to the actual size and volatility of the indicator concerned. The impact of the revision and its interpretation - economic or econometric - therefore also depends on the underlying properties of the corresponding series.

Results for key macroeconomic indicators - appearing in the Monthly Bulletin overview Table - are reported in Table 2 below (further tables with comprehensive similar results for other indicators in the database are appended).

Overall, revisions are somewhat contained, especially on the nominal side whereas they are more substantial on the real side. In addition, there is some evidence of possible biases in the first releases, e.g. GDP tending to be somewhat underestimated by these (in the light of the sign of the computed average errors, revisions were positive overall). The statistical significance of this finding, however, cannot be assessed in view of the limited sample available.

More specifically, all changes in HICP are concentrated in January 2003, when Germany, the Netherlands and Portugal moved their weight reference period from 1995 to 2000, and this caused revisions to the euro area figures. Indeed, before January 2003 there are no revisions at all to the Euro Area HICP, and the same happens from January 2003 to June 2009, the last available vintage.

It should be borne in mind that the series for euro area HICP inflation is a particular case, since revisions to historical data cannot arise from changing the weights attributed to the various country indices entering the euro area aggregation. The series reflects the changing composition for the euro area, so that the entry of new members does not lead to any recomputation of past data and the resulting updated country weights are used only for data subsequent to any given new entry.

For the unemployment rate, most revisions originate in a change in definition that resulted in downward shifts of the unemployment level, affecting the entire time-series. As already mentioned, these earlier revisions do not enter however the reported estimates for the revisions. These changes were due to the harmonisation of the unemployment definitions across the member states, following a European Commission regulation adopted in September 
2000, which member states had two years to implement. According to the old definition, the number of unemployed comprised all those persons above a specified age who were without work, and who were available for work at that time. In addition, they had to have been seeking work by taking specific steps to obtain paid employment or self-employment during the four weeks preceding the interview. However, it was left to the individual countries to set the upper and lower age limits, to define the time that a person may work and still be considered unemployed, and to determine what would be regarded as active or passive steps to find employment. These choices often gave rise to differences across countries before the harmonisation was implemented.

Finally the tables also report summary information on publication lags. The publication lag is defined as the number of months between the reference period and the month in which it is published for the first time in the Monthly Bulletin ${ }^{18}$. For quarterly (annual) series, the publication lag is computed with respect to the last day of the quarter (year). More precisely, the publication month is computed with respect to the end of the month preceding a given Governing Council (for example, if the Economic Sentiment Indicator for February is available early March, i.e. in time for the March Governing Council, then the publication lag is assessed to be 0 month). The publication lag is not the same across vintages as the real-time data flow - in other words, the timing of data releases - has changed over time and correspondingly its relation to the Governing Council dates. In particular, there has been an improvement over the recent years in the timeliness of macroeconomic data (with e.g. the production of "flash" estimates for both GDP and overall HICP). The lag reported in the tables is the one observed in the last available vintage (June 2009).

The publication lag provides important information about the data availability and the realtime data flow for the Euro Area. This information is important also to identify an eventual trade-off between timeliness and accuracy. The relevance of various indicators may also differ in real time, as e.g. price or money data may combine the advantage of being more quickly available than real side series and moreover less subject to data revisions.

Focusing on the main series considered in Chart 1, Eurostat makes unemployment available for the euro area during the first or the second week of the second month following the reference month. For GDP, Eurostat makes a first release available at the beginning of the third month following the end of the reference quarter that is reported in the immediately

\footnotetext{
${ }^{18}$ See also the explanatory note of Table 1.
} 
subsequent Monthly Bulletin. ${ }^{19}$ Industrial Production indices are released in the second third of the second month following the reference month, and therefore published in the Monthly Bulletin of the third month following the reference month. Finally, the euro area HICP is released within the third week of the month following the reference month and is accordingly reported in the Monthly Bulletin of the second month following the reference quarter.

Among other complementary series, the Economic Sentiment Indicator is the most timely information on the real side of the economy. These data are released at the end of the reference month or at the beginning of the following month and hence is available for the first Governing Council of each month. Most revisions to these data relate to the effects of changes in the euro area composition. Another important survey is the Purchasing Managers' Index (PMI) produced by the NTC Economics. The PMI data are especially timely as released just a few days after the end of the reference month. This latter information is however not included in the database for copyright reasons.

When considering all indicators, as reported in the Annex 4, a number of interesting features can be highlighted, focusing specifically on the information provided by analysing the revisions at a less aggregated level. In particular, revisions to the real side (on the Industrial Production e.g.) seem to relate to volatile estimates for some specific sectors, e.g. construction and capital or intermediate goods. Similarly some GDP components tend to be affected by revisions to a relatively larger extent, in particular investment and exports. In some cases, volatile components, e.g. imports for GDP or durable consumer goods for Industrial Production, are nonetheless not significantly revised over time.

\section{Comparison with the United States and Japan}

The size of revisions from one month to another can be compared across the Euro Area, the US and Japan for the following key variables: GDP, Industrial Production, the Unemployment Rate and the CPI. The set of variables is relatively limited, as it is based on series available in the ECB Monthly Bulletin that have been deemed sufficiently

\footnotetext{
${ }^{19}$ Eurostat has produced a "flash" estimate since May 2003, released in the second week of the second month following the end of the reference quarter - this is not published in the subsequent Monthly Bulletin, as the first release becomes available in the meantime. For the euro area aggregate HICP, however, there is, since November 2001, a so-called "flash" estimate that is released immediately after the closing of the month, and hence it is almost always available for the first Governing Council of the month and there is then no publication lag. These "flash" estimates are however not available for either GDP expenditure components or HICP items. The source is europa.eu.int/comm/eurostat/.
} 
comparable..$^{20}$ Figure 3 show "normalised" standard deviations of the revisions for the three countries / areas considered. Standard deviations have been normalised, i.e. divided by the standard deviations of the annual growth rate of the relative series computed on the vintage June 2009. This normalisation allows us to account for possible differences in volatility for the same series across countries, thereby enhancing comparability. If a given series is much more volatile in a country with respect to the other, the revisions could be expected to be of a stronger magnitude without necessarily implying higher relative uncertainty.

First focusing on data release timings and publication lags, it can be seen that for GDP and Industrial Production, the lines for US and Japan start before the euro area. The reason is that in the United States and Japan those variables are always available at least one month before the euro area ones ${ }^{21}$. For unemployment rate, data for both the euro area and Japan are reported to the Governing Council after those for the US. We have however the same timing for consumer prices across the three economic areas.

The earlier reporting for the US relates to the release schedule. In the US, the advance estimate of the GDP is available at the end of the month that follows the last month in the reference quarter, and can then be published in the Monthly Bulletin at the beginning of the second month after the last month in the reference quarter. The US Industrial Production indices are usually released during the second or the third week of the month following the reference month, and are then published in the Monthly Bulletin of the second month following the reference month. The unemployment rate for the US is available during the first or second week of the month following the reference month. For this reason in the Monthly Bulletin of the second month following the reference month, there is always updated data on the US unemployment rate. Both the US consumer price index and the euro area HICP are released within the third week of the month following the reference month, so that they appear in the Monthly Bulletin of the second month following the reference quarter. In general, in Europe the publication lag is much longer for indicators of real economic activity. As a result, the timely but "softer" information provided by surveys may be more valuable in the euro area (such survey data are, as already mentioned, included in the RTDB).

\footnotetext{
${ }^{20}$ For instance monetary aggregates differ substantially in scope across countries (M2 wide for the US has no clear euro area equivalent). See also Branchi et al. (2007) for such country-specific aspects, as well as the following ECB Monthly Bulletin article, on the comparability of international statistics: http:// www.ecb.europa.eu / pub / pdf / other / pp61_72_mb200504en.pdf.

${ }^{21}$ However until the first half of the 2000 the first release of the euro area GDP was published two months later then the U.S. one. The situation has changed since the second quarter of 2002, with now the euro area GDP being available in the Monthly Bulletin three months after the last month of the reference quarter.
} 
As regards revisions, those affecting US GDP are larger over time than those for the euro area. In view of the much earlier GDP data release and correspondingly much lower publication lag for the US, this may suggest a trade-off between timeliness and accuracy. Japanese revisions in comparison even with the US appear very large, converging in magnitude to those seen for the other two GDP series only after some 20 months. This may relate to the sample covered, where Japanese growth has been relatively more volatile, as evidenced by the high coefficient of variation of this series with respect to that for the US, and was therefore perhaps more than proportionately difficult to exactly and timely assess. Recession, deflation or crises periods may result in enhancing such difficulties.

Similar results about the uncertainty of the revisions are obtained for the euro area Industrial Production Index compared with the US ones. An interesting additional finding is that, very much contrary to the GDP results, Japanese revisions seem to be more moderate than those affecting the other two datasets.

Clearly, from the chart, consumer price indexes are never revised in the US, all statistics revisions being zero. All revisions in the euro area are caused, to recall, by a single event in 2003 - when weights changed, see previous section. Bearing this in mind, Japanese figures appear in between, with larger revisions to the initial releases, but quicker convergence to the final estimate, than seen in the euro area.

Analysing the revisions of the unemployment rate series we get opposite results with respect to the ones obtained for GDP and industrial production indices. Indeed, for this variable it seems that revisions are quite larger in the euro area than both in the US and Japan.

\section{Key euro area macroeconomic ratios}

We have now studied the effects of data revision on official statistics over a two-year period. In addition to monitoring such raw data, economists, also in policy institutions, need however to process such data with a view to assessing the state of the economy at a given point in time. The simplest way data are processed is through simple transformations (e.g. ratios) which do not require any econometric work. In this section we illustrate the effect of data revisions on a 
number of such macroeconomic ratios for the euro area, that are key to both economists and policy-makers.

The following illustrative set of ratios has been considered:

- The ratio of real GDP to total employment (Apparent labour productivity);

- The ratio of real consumption to real GDP (Propensity to consume);

- The ratio of real investment to real GDP (Propensity to invest);

- The ratio consumption deflator to GDP deflator (Internal terms of trade).

- The ratio real exports plus real import over twice real GDP (Trade openness).

We aim at assessing whether such key ratios are affected by data revisions to a comparable extent as basic data are, as documented above - revisions to the latter may either offset one another or instead cumulate when considering ratios of interest. Figures 4 show the timeseries for these ratios over all vintages. For labour productivity, we report respectively the yearly growth rate. Revision statistics are reported in Table 4 . Since Trade openness is clearly trended, descriptive statistics are reported for the yearly changes.

Revisions to the growth rate of labour productivity are quite substantial and in fact much larger than the corresponding revisions to both growth rates of GDP (the numerator) and employment (the denominator), which in turn then do not offset each other. These revisions to the growth rate of productivity are an essential feature of all vintages - there are however no evident breaks in 2005 associated with the above-mentioned benchmark revisions in national account and employment. At the same time, these findings indicate that studies analysing productivity gains may be subject to a somewhat high degree of real-time data uncertainty.

Substantial revisions also affect both propensities to consume and invest. The average propensities are between 56 and 59 for consumption and between 19 and 22 for investment. These ranges of variability partly reflect cyclical fluctuations, but also a non-negligible realtime data uncertainty, which can be as large as $2 \%$ for the propensity to consume and $1 \%$ for the propensity to invest. Major revisions took place in 2005 when Eurostat moved from constant prices to chain linking. In view of these results, analyses focusing e.g. on the investment - saving balance for the euro area may not be fully robust to data revisions.

For the internal term of trade, revisions are in terms of size somewhat in between that of the propensity to invest and the propensity to consume. If we exclude a clear outlier corresponding to January 2004, from 2001 onward, the range of revisions has been as large as 
two percent. This is quite significant as the in-sample volatility, for any given vintage of that series, appears closer to one percentage point. This pattern of uncertainty has neither increased not decreased with the benchmark revisions of 2005. These results may mirror corresponding revisions affecting trade deflators on both import and export sides, which have been sizeable. Analyses involving income distribution assessment (such as computations of wage or profit shares) or similarly purchasing power evaluation may therefore also be affected by related data revisions.

Finally, in contrast to the previous ratios, the trade openness appears almost unaffected by revisions across vintages, although trade aggregates were subject to strong revisions over time. The reason is that the ratio exhibits a strong upward trend, reflecting the ongoing process of globalisation. With respect to this dominant pattern, data revisions are negligible. However, the effect of data revisions is more sizeable when looking at annual changes in the trade openness, see Table 4.

Overall, the real-time data uncertainty seems to affect also key ratios to a substantial extent, and not only the basic published series that we analysed earlier. It seems then warranted to systematically complement any economic analysis for the euro area with checks for robustness to such effects, as commonly done by now for the US.

\section{NAIRU computations in real time}

Beyond monitoring key ratios over time on a descriptive basis, economists conduct also some econometric analyses, e.g. to derive other key magnitudes that are representative of the economy. Such results may obviously also not be immune to data revisions, given what we already demonstrated by looking at simple key ratios. To illustrate that point, we now study the impact of data revisions on the real-time assessment of the Non Accelerating Inflation Rate of Unemployment (NAIRU) for the euro area. The NAIRU is estimated following Staiger, Stock and Watson (1997). We strictly aim at showing the possible impact of data revisions on given econom(etr)ic results, and therefore do not intend to conclude on the actual level or evolution over time of the NAIRU for the euro area - in a given sample, the model 
employed e.g. assumes that the NAIRU is constant in-sample. Many different alternative methods can be used for NAIRU computations, leading to varied views as to which extent and why the NAIRU changes over time. Such investigation is beyond the scope of this paper.

Staiger, Stock and Watson (1997) propose to determine the NAIRU using the following relation, according to which if unemployment remains fixed at the NAIRU value, then inflation does not change:

$$
\Delta \pi_{t}=\beta_{1}\left(U_{t-1}-\mu\right)+\beta_{2}\left(U_{t-2}-\mu\right)+\gamma X+\varepsilon_{t}
$$

where $\pi_{t}$ is the rate of inflation (computed using HICP excluding energy and unprocessed food), $U_{\mathrm{t}}$ is the unemployment rate and $X_{t}$ denotes additional control variables - in the case at hand, one lag of the change in inflation and of the change in oil price inflation.

The NAIRU, $\mu$ enters the formula as an unknown parameter. This relation cannot be easily estimated because the model is non-linear in its parameters. For this reason Staiger, Stock and Watson (1997) suggest estimating the following relation instead:

$$
\Delta \pi_{t}=\alpha+\beta_{1} U_{t-1}+\beta_{2} U_{t-2}+\gamma X+e_{t}
$$

Given the ordinary least square estimates of the constant term $\alpha$ and coefficients $\beta_{1}$ and $\beta_{2}$, the unique value of the NAIRU for any given data sample can then be estimated as:

$$
-\frac{\alpha}{\beta_{1}+\beta_{2}}
$$

On this basis, we have derived the euro area NAIRU from all available vintages. We also computed the uncertainty surrounding this indicator, using the Fieller's method as also proposed in Staiger, Stock and Watson $(1997)^{22}$. This uncertainty reflects that pertaining to parameters in this given model, not the uncertainty arising from the already mentioned fact that other possible modelling strategies are available to compute the NAIRU.

\footnotetext{
22 Confidence bands are computed as in Staiger, Stock and Watson (1997) by using an extension of a technique originally proposed by E.C. Fieller (1954) to construct a confidence interval for the ratio of the means of two dependent normal random variables.
} 
We wish to eventually check whether the NAIRU computed on the last available vintage still lays within the resulting (econometric) confidence intervals constructed in real time using past available vintages, in other words, whether the real-time uncertainty is econometrically significant in that specific case. We also then need however to also account for the fact that revisions can arise from data availability, since for each vintage the model is estimated with different samples of available data. In order to assess the relative importance of this uncertainty, we perform a standard pseudo-real-time exercise where we isolate the effect of data revisions by estimating the NAIRU using the data of the last available vintage but preserving the real-time pattern of data availability. More in detail, for each month of our database, we identify which sample of backdata was then was available,in the corresponding issue if the ECB Monthly Bulletin; we then substitute for each observation in that sample the value reported in the latest available vintage of data, June 2009 , to the release then available in the ECB Monthly Bulletin.

Figure 5 reports the results of the computations, showing the real-time NAIRU - along with the associated confidence interval, the pseudo-real-time NAIRU, and the NAIRU from the last available vintage (denoted "Last NAIRU"). We also report the real-time unemployment gap, defined as the difference between unemployment and the NAIRU. This variable can be interpreted as an indicator of forthcoming inflationary pressures according to equation (1.1).

Results first show that recursive estimates of the NAIRU changes quite substantially over time. Real-time and pseudo-real-time estimates are moreover quite different over the whole sample from the NAIRU computed using only the last available vintage of data. This indicates that both data revisions and data availability are important sources of the overall realtime uncertainty. However, data availability plays a larger role when the NAIRU is computed with the earlier vintages - using data up to the June 2003 ECB Monthly Bulletin - where the estimation sample remains short. Differences between real-time and pseudo-real-time estimates become smaller when computed using more recent vintages.

However, both the pseudo-real-time and the last-vintage NAIRUs remain within the confidence bands around the real-time NAIRU. This indicates that the combined variation from both data availability and data revisions remain well below that uncertainty affects the accuracy with which the parameters of this given model can be estimated.

Finally, an interesting side-finding of this illustrative exercise, is that, as seen on Figure 6, the focus on the unemployment gap as such can be misplaced - even regardless of parameter or model uncertainty considerations. Data uncertainty per se suffices to render the interpretation 
of such variables highly dubious, as for instance can be documented for the periods 2000-02 and 2003-06 where, respectively, the gap is subject to a measurement error of close to 2 p.p. and there is even uncertainty on the very sign of the unemployment gap.

\section{Summary and Conclusions}

We have described the construction of, and documented, an euro area-wide real-time database, comprising a large number of series, as reported in the ECB Monthly Bulletin. The monthly vintages of the underlying ECB Monthly Bulletin data are made available for external use via the EABCN website and the ECB Statistical Data Warehouse and are regularly updated on a quarterly basis. This database will provide users with regular snapshots of area-wide data, as available to the euro area Governing Council at the beginning of each month.

We have studied the real-time data revision and data-flow processes in the euro area and compared it with those for the US and Japan. Revisions for the euro area appeared especially on the real side as relatively limited in comparison, this being possibly connected to a less quick delivery of first estimates.

At the same time, revisions to euro area macroeconomic data can be substantial enough to affect the assessment of the macro-economic situation in the euro area at a given point in time. For instance, GDP composition or Industrial Production indices can experience important changes over time. Also the unemployment rate or the saving ratio are typically subject to sizeable revisions, albeit mostly affecting the level rather than the trends in the reviewed series. Labour productivity trends or the degree of openness seem to be less affected than other key ratios such as terms of trade or propensities to consume or invest out of GDP.

We have also provided real-time and pseudo-real-time NAIRU estimates for the euro area on the basis of this ECB Monthly Bulletin euro area-wide database and showed that the uncertainty relating to data revision issues albeit sizeable, would be dominated by that arising from the estimation of the parameters.

We plan to use further this comprehensive euro area dataset and would also welcome any further use of such data by researchers. 


\section{Bibliography}

Anderson, R. G. (2006). "Replicability, real-time data, and the science of economic research: FRED, ALFRED, and VDC," Review, Federal Reserve Bank of St. Louis, issue Jan, pages 8193.

Branchi, M., H. C. Dieden, W. Haine, C. Horváth, A. Kanutin and L. Kezbere (2007) "Analysis of revisions to general economic statistics", ECB Occasional Paper .

Castle, J and C. Ellis (2002). "Building a Real-Time Database for GDP(E)." Bank of England Quarterly Bulletin (Spring 2002), pp. 42-49.

Croushore, D. and T. Stark (2001) "A Real-Time Data Set for Macroeconomists," Journal of Econometrics 105, pp. 111-130.

Croushore, D., and T. Stark (2005), “A Real Time Data Set for Macroeconomists: Does the Data Vintage Matter?" Review of Economics and Statistics 85 (August): 605-17.

Croushore, D. (2006): "Forecasting with Real-Time Macroeconomic Data." In: Graham Elliott, Clive W.J. Granger, and Allan Timmermann, eds., Handbook of Economic Forecasting (Amsterdam: North-Holland), pp. 961-982.

Fair, R. C. and R. J. Shiller (1990) "Comparing Information in Forecasts from Econometric Models," American Economic Review 80, pp. 375-89.

Giannone, D., L. Reichlin and S. Simonelli (2009) "Do Surveys Forecast Real Economic Activity”, National Institute Economic Review, No. 210, October 2009.

Jenkinson, G. (2004) “ONS Policy on Standards for Presenting Revisions Analysis in Time Series First Releases", Economic Trends, No. 604, March 2004

Kaufmann, S. and P. Kugler (2009), "A monetary real time conditional forecast of euro area inflation”, Journal of Forecasting, Early View, June 2009.

Ladiray, D., G.-L.Mazzi and R. Ruggeri-Cannata (2008), "Euro area data: Issues and implications for economic analysis”, EABCN Workshop, Cambridge, March 2008. 
Marcellino, M. and A. Musso (2008) "Real-time estimates of the euro area output gap reliability and inflation forecast performance", mimeo ECB.

OECD (2003). Undertaking Revisions and Real-Time Data Analysis using the OECD Main Economic Indicators Original Release Data and Revisions Database. OECD Statistics Working Paper

Orphanides, A. and S. van Norden, 2002. "The Unreliability of Output-Gap Estimates in Real Time," The Review of Economics and Statistics, MIT Press, vol. 84(4), pages 569-583, 07.

Orphanides, A., 2001. "Monetary Policy Rules Based on Real-Time Data," American Economic Review, vol. 91(4), pages 964-985, September.

Swanson, N. R. (1996) "Forecasting Using First Available Versus Fully Revised Economic Time Series Data,” Working Paper No. 4-96-7, Pennsylvania State University.

\section{Selected web resources}

http://www.oncampus.richmond.edu/ dcrousho/docs/realtime_lit.pdf

http://www.philadelphiafed.org/econ/forecast/real-time-data/index.cfm

http://research.stlouisfed.org/tips/alfred/

http://stats.oecd.org/mei/default.asp?rev=1

http://www.bankofengland.co.uk/statistics/gdpdatabase/

http://www.bundesbank.de/vfz/vfz_echtzeitdaten.en.php

http://www.eabcn.org/data/rtdb/euro_area_rtdb.htm 
Table 1: The composition of the dataset - based on the ECB Monthly Bulletin presentation and methodological approach

\begin{tabular}{|c|c|c|c|}
\hline BLOCK NAME & $\begin{array}{l}\text { NUMBER. } \\
\text { OF SERIES }\end{array}$ & $\begin{array}{l}\text { BACKDATA } \\
(\text { AT LEAST SINCE*) }\end{array}$ & $\begin{array}{l}\text { PUBLICAT } \\
\text { ION LAG } \\
\text { (MAXIMUM**) } \\
\end{array}$ \\
\hline \multicolumn{4}{|c|}{ MONTHLY SERIES } \\
\hline $\begin{array}{l}\text { Industrial production: by industry (breakdown by end-use of products- } \\
\text { is the harmonised sub-division of industry excluding construction } \\
\text { (NACE section C to E) into main industrial groupings (MIGs)). }\end{array}$ & 12 & January 1990 & 2 months \\
\hline Retail sales: by type of goods & 10 & January 1995 & 1 month \\
\hline Unemployment and unemployment rate: by gender and by age groups & 10 & January 1996 & 1 month \\
\hline $\begin{array}{l}\text { Harmonised Index of Consumer Prices (incl. breakdown be goods and } \\
\text { services components) }\end{array}$ & 15 & January 1995 & 1 month \\
\hline External transactions and position & 13 & January 1999 & 2 months \\
\hline Exchange rates: effective exchange rates & 5 & January 1998 & 0 months \\
\hline Trade in goods: value, volume and unit value by product group & 39 & January 2000 & 3 months \\
\hline Interest rate, money market overnight to $12 \mathrm{mths}$, US and Japan $3 \mathrm{mths}$ & 7 & January 1994 & 0 months \\
\hline Government bond yield 2, 3, 5, 7, 10 years, US and Japan, 10 years & 7 & January 1994 & 0 months \\
\hline Dow Jones EURO STOXX, S\&P and Nikkei & 14 & January 1994 & 0 months \\
\hline US and Japan: main economic and financial indicators & 9 & January 1978 & 1 month \\
\hline Industry and commodity prices: by type of goods and by industry & 13 & January 1991 & 1 month \\
\hline Money supply M1 M2 M3, Base money, Total loans, Total credit & 7 & February 1999 & 1 month \\
\hline Money supply M1 M2 M3, Base money, Total loans, Total credit & 7 & February 1999 & 1 months \\
\hline Confidence indicators, business and consumers & 21 & April 1995 & 0 months \\
\hline \multicolumn{4}{|c|}{ QUARTERLY SERIES } \\
\hline Employment: by employment status, by economic activity & 10 & Q1 1995 & 3 months \\
\hline GDP deflators: by expenditure components & 7 & Q1 1995 & 2 months \\
\hline Unit labour cost: by economic activity & 7 & Q1 1995 & 4 months \\
\hline Hourly labour cost: by components and by economic activity & 7 & Q1 1996 & 3 months \\
\hline Exchange rates: effective exchange rates & 1 & Q4 1995 & 3 months \\
\hline US and Japan: main economic and financial indicators & 23 & Q1 1995 & 3 months \\
\hline $\begin{array}{l}\text { Industry and commodity prices: by type of goods and by industry } \\
\text { (Construction output prices, All residential buildings) }\end{array}$ & 1 & Q1 1985 & 6 months \\
\hline GDP: by expenditure components at current prices & 7 & Q1 1995 & 2 months \\
\hline GDP: by expenditure components at constant prices & 7 & Q1 1995 & 2 months \\
\hline GDP: by expenditure components at constant prices & 7 & Q1 1995 & 2 months \\
\hline Value added: by economic activity at current prices & 9 & Q1 1995 & 2 months \\
\hline Value added: by economic activity at constant prices & 9 & Q1 1995 & 2 months \\
\hline $\begin{array}{l}\text { Confidence indicators: economic construction: (Industry Survey: } \\
\text { Current level of capacity utilization) }\end{array}$ & 1 & Q1 1985 & 0 months \\
\hline \multicolumn{4}{|l|}{ ANNUAL SERIES } \\
\hline Government finance: deficit/surplus and government consumption & 14 & 1995 & 4 months \\
\hline US and Japan: main economic and financial indicators & 6 & 1998 & 13 months \\
\hline
\end{tabular}

(*): Observations for all series in a given block are available at least since the date below for all vintages of the dataset. (**): We report the publication lag computed using the last available vintage (Sept. 07). If the series within a block have different publication lags we report the maximum lag. The publication lag is computed with respect to the end of the month preceding a given Governing Council - e.g. when the data for February is available early March, i.e. in time for the March Governing Council, then the Publication Lag is assessed to be 0 month. For quarterly series the Publication Lag is computed with respect to the last day of the quarter. For annual series the Publication Lag is computed with respect to the last day of the year 
Table 2: Revision statistics for main economic indicators of the ECB Monthly Bulletin

Summary of economic indicators for the euro area

\begin{tabular}{|c|c|c|c|c|c|c|c|c|c|c|c|}
\hline & HICP & $\begin{array}{r}\text { Industrial } \\
\text { producer } \\
\text { prices }\end{array}$ & $\begin{array}{r}\text { Hourly } \\
\text { labour } \\
\text { costs }\end{array}$ & $\begin{array}{r}\text { GDP } \\
\text { deflator }\end{array}$ & M3 & Real GDP & $\begin{array}{r}\text { Industrial } \\
\text { production } \\
\text { excluding } \\
\text { construction } \\
7 \\
7\end{array}$ & $\begin{array}{r}\text { Economic } \\
\text { sentiment } \\
\text { indicator }\end{array}$ & $\begin{array}{r}\text { Capacity } \\
\text { utilisation in } \\
\text { manufacturing } \\
\text { (percentages) } \\
9\end{array}$ & Employment & $\begin{array}{l}\text { Unemployment } \\
\text { (\% of labour } \\
\text { force) }\end{array}$ \\
\hline \multicolumn{12}{|c|}{ Mean of the series } \\
\hline & 2.27 & 2.79 & 3.05 & 2.16 & 7.75 & 1.65 & 1.38 & 97.88 & 81.68 & 1.17 & 8.34 \\
\hline \multicolumn{12}{|c|}{ Mean of revisions } \\
\hline$(t \mathrm{tt}+4)-\mathrm{Y}(\mathrm{ttl}+24)$ & 0.03 & 0.02 & -0.14 & -0.08 & 0.02 & -0.15 & -0.21 & 1.74 & -0.08 & -0.18 & -0.06 \\
\hline$(\mathrm{ttl}+6)-\mathrm{Y}(\mathrm{ttl}+24)$ & 0.03 & 0.03 & -0.13 & -0.12 & 0.03 & -0.14 & -0.11 & 1.65 & -0.06 & -0.16 & -0.06 \\
\hline$(\mathrm{ttl}+8)-\mathrm{Y}(\mathrm{tt}+24)$ & 0.02 & 0.03 & -0.09 & -0.11 & 0.03 & -0.12 & -0.08 & 1.56 & -0.04 & -0.12 & -0.06 \\
\hline$(\mathrm{ttl}+12)-\mathrm{Y}(\mathrm{tlt}+24)$ & 0.02 & 0.03 & -0.06 & -0.11 & 0.00 & -0.10 & -0.05 & 1.18 & 0.00 & -0.10 & -0.04 \\
\hline$Y(t \mathrm{tl}+16)-\mathrm{Y}(\mathrm{tlt}+24)$ & 0.01 & 0.03 & 0.01 & -0.08 & -0.01 & -0.07 & -0.04 & 0.70 & 0.02 & -0.05 & -0.03 \\
\hline \multicolumn{12}{|c|}{ Standard deviation of the series } \\
\hline & 0.59 & 2.46 & 0.57 & 0.32 & 2.05 & 1.57 & 3.34 & 10.47 & 2.67 & 0.64 & 0.58 \\
\hline \multicolumn{12}{|c|}{ Standard deviation of revisions } \\
\hline$Y(t \mathrm{tt}+4)-Y(t \mathrm{tlt}+24)$ & 0.10 & 0.13 & 0.27 & 0.22 & 0.21 & 0.19 & 0.40 & 2.46 & 0.22 & 0.20 & 0.27 \\
\hline$Y(t t+6)-Y(t t t+24)$ & 0.09 & 0.12 & 0.26 & 0.14 & 0.20 & 0.17 & 0.38 & 2.23 & 0.21 & 0.18 & 0.25 \\
\hline$(t \mathrm{tt}+8)-\mathrm{Y}(\mathrm{t} t \mathrm{t}+24)$ & 0.07 & 0.11 & 0.26 & 0.14 & 0.19 & 0.14 & 0.31 & 1.98 & 0.18 & 0.15 & 0.24 \\
\hline$Y(t t+12)-Y(t \mathrm{tl}+24)$ & 0.06 & 0.10 & 0.21 & 0.12 & 0.07 & 0.12 & 0.23 & 1.61 & 0.14 & 0.10 & 0.19 \\
\hline$Y(t t+16)-Y(t t+24)$ & 0.04 & 0.08 & 0.20 & 0.13 & 0.06 & 0.09 & 0.15 & 1.27 & 0.16 & 0.12 & 0.15 \\
\hline \multicolumn{12}{|c|}{ Publication lag (months) } \\
\hline
\end{tabular}

Sources: ECB and European Commission (Eurostat and Economic and Financial Affairs DG)

This table shows some summary statistics about some key series and their revisions. We report the Mean of the series and the Standard deviation of the series that can be used as term of comparison for understanding the dimension of mean and standard deviation of the revisions. We report then the mean and the standard deviation of the revisions defined as $Y(t \mid t+i)-Y(t \mid t+24)$, where $t$ indicates the reference period, while $\mathrm{t}+\mathrm{i}$ - for $\mathrm{i}=4,6,8,12,16$ - is the time in which the value of the series is observed and we consider the observation available two years later - Y $(t \mid t+24)$ - the "true value". The row Publication lag indicates how many months later the reference period the first observation is available (for quarterly/annual series we count from the last month in the quarter/year) 
Table 3: Revision statistics for US and Japan key indicators

T3 In the United States and Japan annual percentage changes, unless otherwise indicated)

1. Economic and financial developments

\begin{tabular}{|c|c|c|c|c|c|c|}
\hline & $\begin{array}{r}\text { Consumer } \\
\text { price index }\end{array}$ & $\begin{array}{r}\text { Unit labour } \\
\text { costs } \\
\text { (manufacturing) }\end{array}$ & Real GDP & 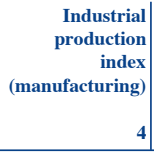 & $\begin{array}{r}\text { Unemployment } \\
\text { rate } \\
\text { as a \% of } \\
\text { labour force } \\
\text { (s.a.) } \\
5\end{array}$ & $\begin{array}{l}\text { Broad } \\
\text { money }\end{array}$ \\
\hline \multicolumn{7}{|c|}{ United States } \\
\hline \multicolumn{7}{|c|}{ Mean of the series } \\
\hline & 2.73 & 1.26 & 2.08 & 0.23 & 5.36 & 6.30 \\
\hline \multicolumn{7}{|c|}{ Mean of revisions } \\
\hline $\mathrm{Y}(\mathrm{tlt}+4)-\mathrm{Y}(\mathrm{ttl}+24)$ & 0.00 & 0.65 & 0.49 & 0.37 & 0.00 & 0.54 \\
\hline $\mathrm{Y}(\mathrm{tlt}+6)-\mathrm{Y}(\mathrm{ttl}+24)$ & 0.00 & 0.61 & 0.48 & 0.33 & 0.01 & 0.48 \\
\hline $\mathrm{Y}(\mathrm{ttl}+8)-\mathrm{Y}(\mathrm{tt}+24)$ & 0.00 & 0.67 & 0.45 & 0.27 & 0.01 & 0.40 \\
\hline $\mathrm{Y}(\mathrm{tlt}+12)-\mathrm{Y}(\mathrm{tlt}+24)$ & 0.00 & 0.46 & 0.36 & 0.21 & 0.01 & 0.24 \\
\hline $\mathrm{Y}(\mathrm{ttl}+16)-\mathrm{Y}(\mathrm{tt}+24)$ & 0.00 & -0.01 & 0.24 & 0.18 & 0.00 & 0.09 \\
\hline \multicolumn{7}{|c|}{ Standard deviation of the series } \\
\hline & 1.19 & 3.05 & 1.39 & 4.36 & 0.88 & 1.73 \\
\hline \multicolumn{7}{|c|}{ Standard deviation of revisions } \\
\hline $\mathrm{Y}(\mathrm{tlt}+4)-\mathrm{Y}(\mathrm{tt}+24)$ & 0.00 & 3.13 & 0.29 & 1.01 & 0.06 & 1.57 \\
\hline $\mathrm{Y}(\mathrm{tlt}+6)-\mathrm{Y}(\mathrm{tt}+24)$ & 0.00 & 3.06 & 0.29 & 0.97 & 0.06 & 1.31 \\
\hline $\mathrm{Y}(\mathrm{tt}+8)-\mathrm{Y}(\mathrm{tt}+24)$ & 0.00 & 2.79 & 0.30 & 0.94 & 0.05 & 1.08 \\
\hline $\mathrm{Y}(\mathrm{tt}+12)-\mathrm{Y}(\mathrm{tt}+24)$ & 0.00 & 2.96 & 0.31 & 0.93 & 0.05 & 0.75 \\
\hline $\mathrm{Y}(\mathrm{ttl}+16)-\mathrm{Y}(\mathrm{tt}+24)$ & 0.00 & 2.75 & 0.25 & 0.87 & 0.03 & 0.35 \\
\hline \multicolumn{7}{|c|}{ Publication lag (months) } \\
\hline & 1 & 2 & 1 & 1 & 1 & 1 \\
\hline \multicolumn{7}{|c|}{ Japan } \\
\hline \multicolumn{7}{|c|}{ Mean of the series } \\
\hline & -0.08 & -1.88 & 1.39 & -0.55 & 4.60 & 1.70 \\
\hline \multicolumn{7}{|c|}{ Mean of revisions } \\
\hline $\mathrm{Y}(\mathrm{tt} t+4)-\mathrm{Y}(\mathrm{tt}+24)$ & 0.05 & 0.00 & 0.32 & -0.12 & 0.00 & 0.05 \\
\hline $\mathrm{Y}(\mathrm{tlt}+6)-\mathrm{Y}(\mathrm{tt}+24)$ & 0.03 & 0.05 & 0.27 & -0.12 & -0.01 & 0.03 \\
\hline $\mathrm{Y}(\mathrm{tlt}+8)-\mathrm{Y}(\mathrm{tlt}+24)$ & 0.01 & 0.11 & 0.22 & -0.14 & -0.01 & 0.03 \\
\hline $\mathrm{Y}(\mathrm{ttl}+12)-\mathrm{Y}(\mathrm{tt}+24)$ & -0.01 & 0.19 & 0.18 & -0.12 & 0.00 & 0.02 \\
\hline $\mathrm{Y}(\mathrm{ttl}+16)-\mathrm{Y}(\mathrm{tt}+24)$ & -0.01 & 0.15 & 0.14 & -0.08 & 0.00 & 0.02 \\
\hline \multicolumn{7}{|c|}{ Standard deviation of the series } \\
\hline & 0.73 & 4.33 & 1.66 & 8.78 & 0.56 & 0.51 \\
\hline \multicolumn{7}{|c|}{ Standard deviation of revisions } \\
\hline $\mathrm{Y}(\mathrm{tlt}+4)-\mathrm{Y}(\mathrm{tt}+24)$ & 0.16 & 0.65 & 1.26 & 0.57 & 0.05 & 0.08 \\
\hline $\mathrm{Y}(\mathrm{ttl}+6)-\mathrm{Y}(\mathrm{ttt}+24)$ & 0.13 & 0.63 & 1.22 & 0.56 & 0.05 & 0.06 \\
\hline $\mathrm{Y}(\mathrm{tlt}+8)-\mathrm{Y}(\mathrm{tt}+24)$ & 0.10 & 0.62 & 1.11 & 0.52 & 0.05 & 0.06 \\
\hline $\mathrm{Y}(\mathrm{tt}+12)-\mathrm{Y}(\mathrm{tt}+24)$ & 0.05 & 0.53 & 0.84 & 0.46 & 0.05 & 0.04 \\
\hline $\mathrm{Y}(\mathrm{ttl}+16)-\mathrm{Y}(\mathrm{tt}+24)$ & 0.05 & 0.43 & 0.73 & 0.35 & 0.04 & 0.04 \\
\hline \multicolumn{7}{|c|}{ Publication lag (months) } \\
\hline & 1 & 3 & 2 & 1 & 1 & 1 \\
\hline
\end{tabular}

Sources: National data (columns 1, 2 (United States), 3, 4, 5 (United States), and 6); OECD (column 2 (Japan)); Eurostat (column 5 (Japan)).

This table shows some summary statistics about some key series and their revisions. We report the Mean of the series and the Standard deviation of the series that can be used as term of comparison for understanding the dimension of mean and standard deviation of the revisions. We report then the mean and the standard deviation of the revisions defined as $\mathrm{Y}(\mathrm{t} \mid \mathrm{t}+\mathrm{i})-\mathrm{Y}(\mathrm{t} \mid \mathrm{t}+24)$, where $\mathrm{t}$ indicates the reference period, while $\mathrm{t}+\mathrm{i}$ - for $\mathrm{i}=4,6,8,12,16$ - is the time in which the value of the series is observed and we consider the observation available two years later - Y $(t \mid t+24)$ - the "true value". The row Publication lag indicates how many months later the reference period the first observation is available (for quarterly/annual series we count from the last month in the quarter/year) 
Table 4: Revision statistics for Apparent labour productivity, Propensity to consume, Propensity to invest, Internal terms of trade and Trade openness.

\begin{tabular}{|c|c|c|c|c|c|}
\hline Ratios & & & & & \\
\hline & 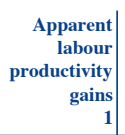 & $\begin{array}{r}\text { Propensity } \\
\text { to } \\
\text { consume } \\
2\end{array}$ & $\begin{array}{r}\text { Propensity } \\
\text { to } \\
\text { invest } \\
3\end{array}$ & 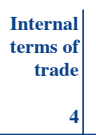 & $\begin{array}{r}\text { Trade } \\
\text { openness } \\
\text { differences } \\
5\end{array}$ \\
\hline \multicolumn{6}{|c|}{ Mean of the series } \\
\hline & 2.37 & 57.33 & 21.27 & 100.68 & 40.38 \\
\hline \multicolumn{6}{|c|}{ Mean of revisions } \\
\hline $\mathrm{Y}(\mathrm{ttl}+4)-\mathrm{Y}(\mathrm{ttl}+24)$ & $\begin{array}{l}-0.02 \\
\end{array}$ & -0.43 & -0.17 & 0.37 & -0.03 \\
\hline $\mathrm{Y}(\mathrm{tt}+6)-\mathrm{Y}(\mathrm{tlt}+24)$ & -0.02 & -0.38 & -0.13 & 0.40 & -0.08 \\
\hline $\mathrm{Y}(\mathrm{t} t+8)-\mathrm{Y}(\mathrm{t} t+24)$ & -0.02 & -0.37 & -0.11 & 0.33 & -0.10 \\
\hline $\mathrm{Y}(\mathrm{tt}+12)-\mathrm{Y}(\mathrm{tt}+24)$ & -0.01 & -0.25 & -0.07 & 0.31 & -0.07 \\
\hline $\mathrm{Y}(\mathrm{tt}+16)-\mathrm{Y}(\mathrm{tt}+24)$ & -0.04 & -0.17 & -0.04 & 0.13 & -0.02 \\
\hline \multicolumn{6}{|c|}{ Standard deviation of the series } \\
\hline & 0.86 & 0.59 & 0.53 & 0.44 & 2.95 \\
\hline \multicolumn{6}{|c|}{ Standard deviation of revisions } \\
\hline $\mathrm{Y}(\mathrm{tt}+4)-\mathrm{Y}(\mathrm{tt}+24)$ & 0.26 & 0.58 & 0.18 & 0.37 & 0.35 \\
\hline $\mathrm{Y}(\mathrm{tlt}+6)-\mathrm{Y}(\mathrm{tt}+24)$ & 0.20 & 0.53 & 0.17 & 0.33 & 0.30 \\
\hline $\mathrm{Y}(\mathrm{ttl}+8)-\mathrm{Y}(\mathrm{tt}+24)$ & 0.17 & 0.52 & 0.16 & 0.32 & 0.27 \\
\hline $\mathrm{Y}(\mathrm{tt}+12)-\mathrm{Y}(\mathrm{tt}+24)$ & 0.20 & 0.42 & 0.15 & 0.32 & 0.37 \\
\hline $\mathrm{Y}(\mathrm{ttlt}+16)-\mathrm{Y}(\mathrm{tt}+24)$ & 0.17 & 0.36 & 0.14 & 0.30 & 0.33 \\
\hline
\end{tabular}

Sources: ECB calculations based on Eurostat data.

This table shows some summary statistics about some key big ratios and their revisions. We report the Mean of the ratios and the Standard deviation of the ratios that can be used as term of comparison for understanding the dimension of mean and standard deviation of the revisions. We report then the mean and the standard deviation of the revisions defined as $Y(t \mid t+i)-Y(t \mid t+24)$, where $t$ indicates the reference period, while $\mathrm{t}+\mathrm{i}$ - for $\mathrm{i}=4,6,8,12,16$ - is the time in which the value of the series is observed and we consider the observation available two years later - Y(t|t+24) - the "true value". 
Figure 1a: Vintages for GDP- euro area data.

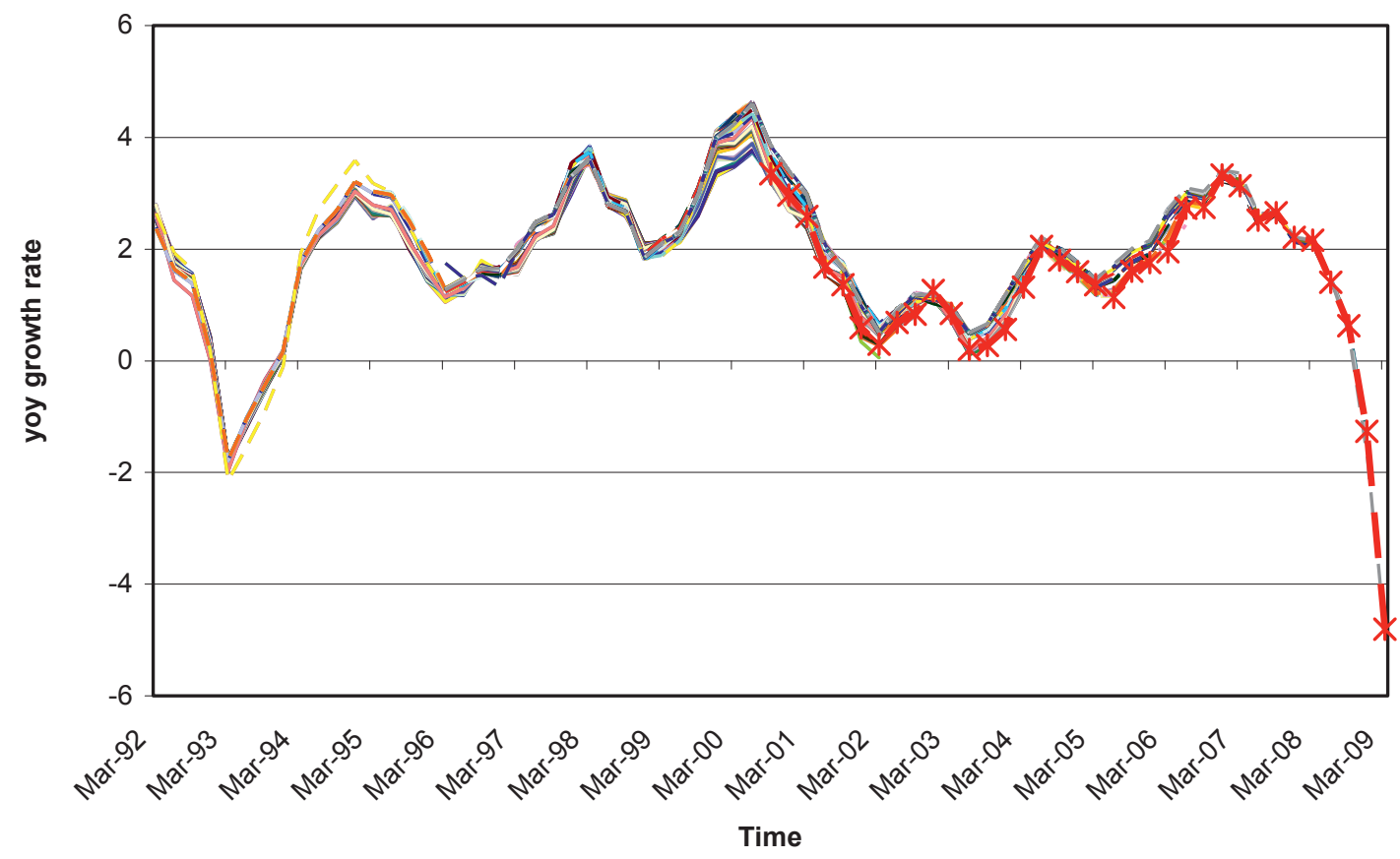

This Figure shows the evolution of the GDP annual growth rate through vintages. The different lines are the plots of the GDP series for all the available vintages. At each point in time each plot indicates the value of the GDP annual growth rate, relative to that point in time, but for a different vintage. The crosses indicate the last observation in each vintage. 
Figure 1b: Vintages for HICP- euro area data.

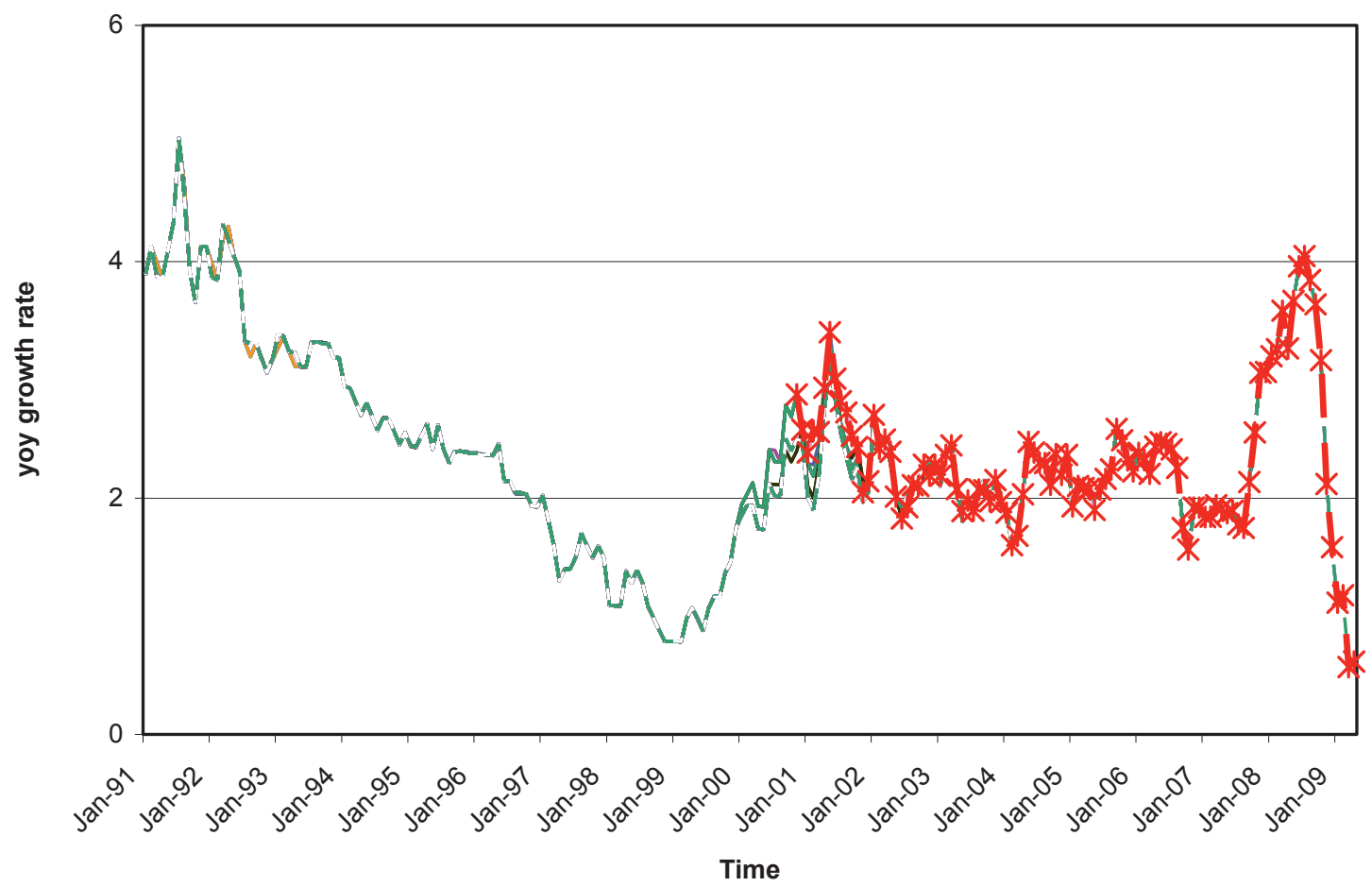

This Figure shows the evolution of the annual inflation through vintages. The different lines are the plots of the inflation series for all the available vintages. At each point in time each plot indicates the value of the annual inflation, relative to that point in time, but for a different vintage. The crosses indicate the last observation in each vintage. 
Figure 1c: Vintages for Industrial Production - euro area data.

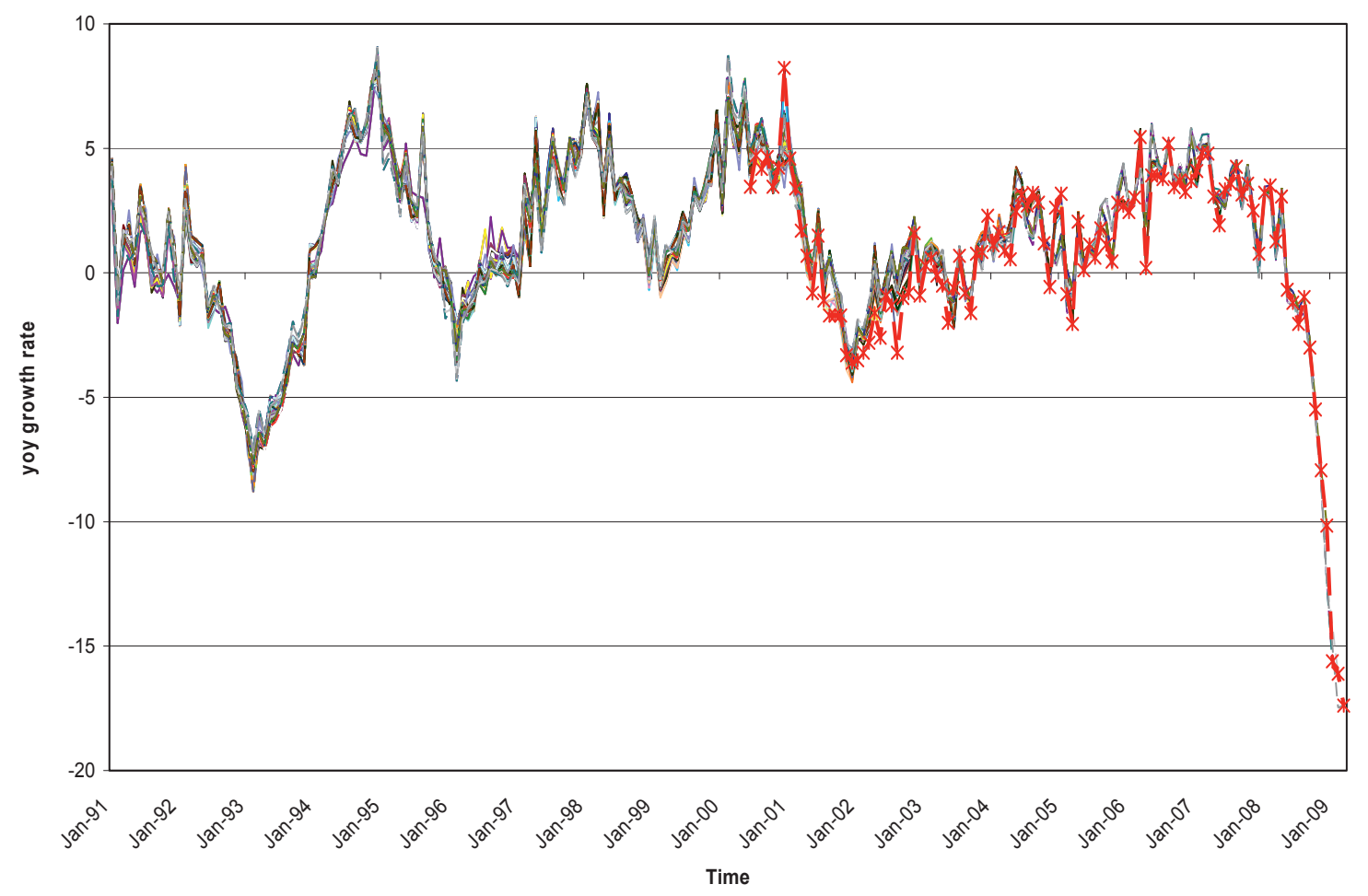

This Figure shows the evolution of the Industrial Production annual growth rate through vintages. The different lines are the plots of the Industrial Production series for all the available vintages. At each point in time each plot indicates the value of the Industrial Production annual growth rate relative to that point in time, but for a different vintage. The crosses indicate the last observation in each vintage. 
Figure 1d: Vintages for Unemployment- euro area data.

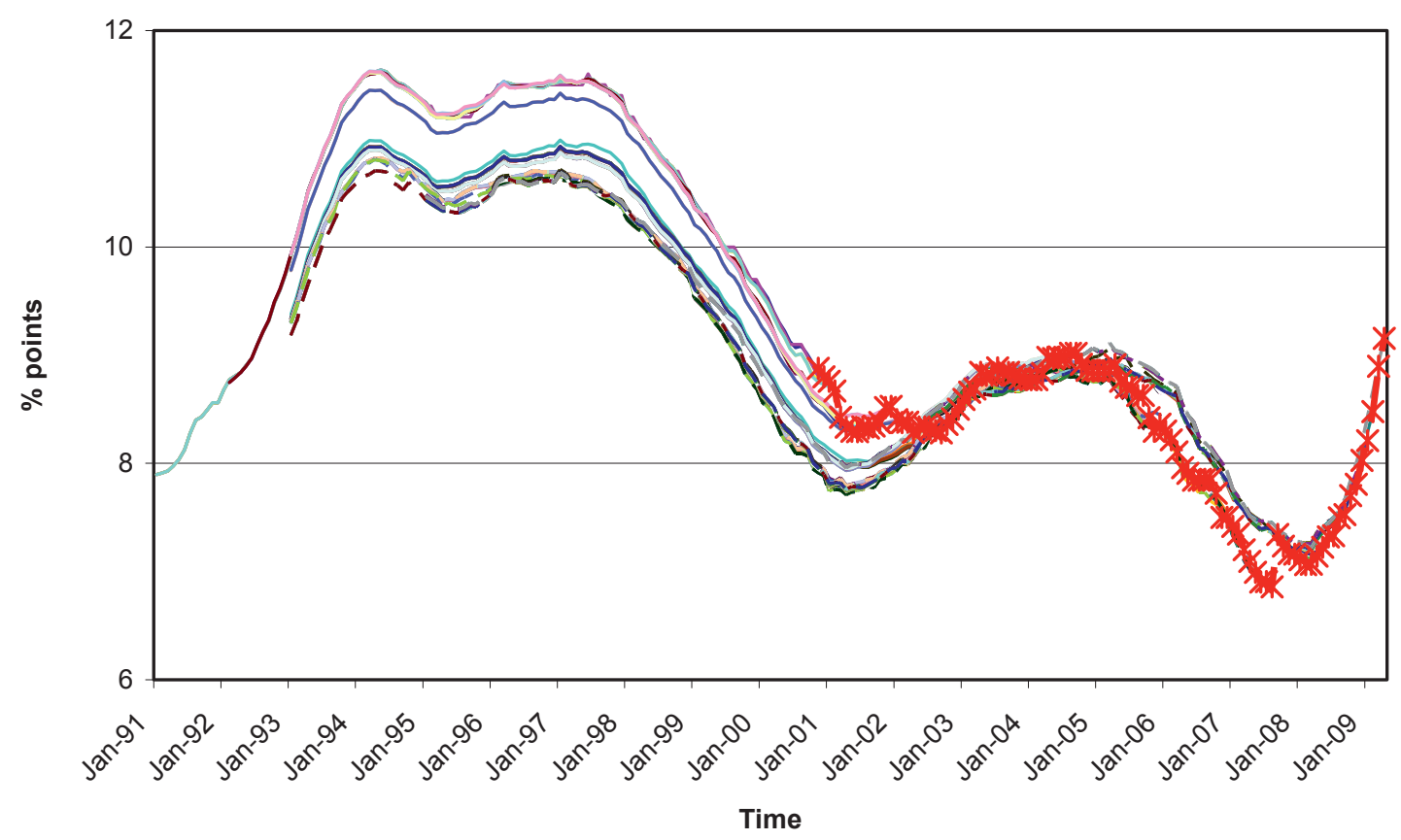

This Figure shows the evolution of the Unemployment through vintages. The different lines are the plots of the Unemployment series for all the available vintages. At each point in time each plot indicates the value of the Unemployment rate relative to that point in time, but for a different vintage. The crosses indicate the last observation in each vintage. 
Figure 2: GDP growth rate for the fourth quarter of 2001 - successive releases

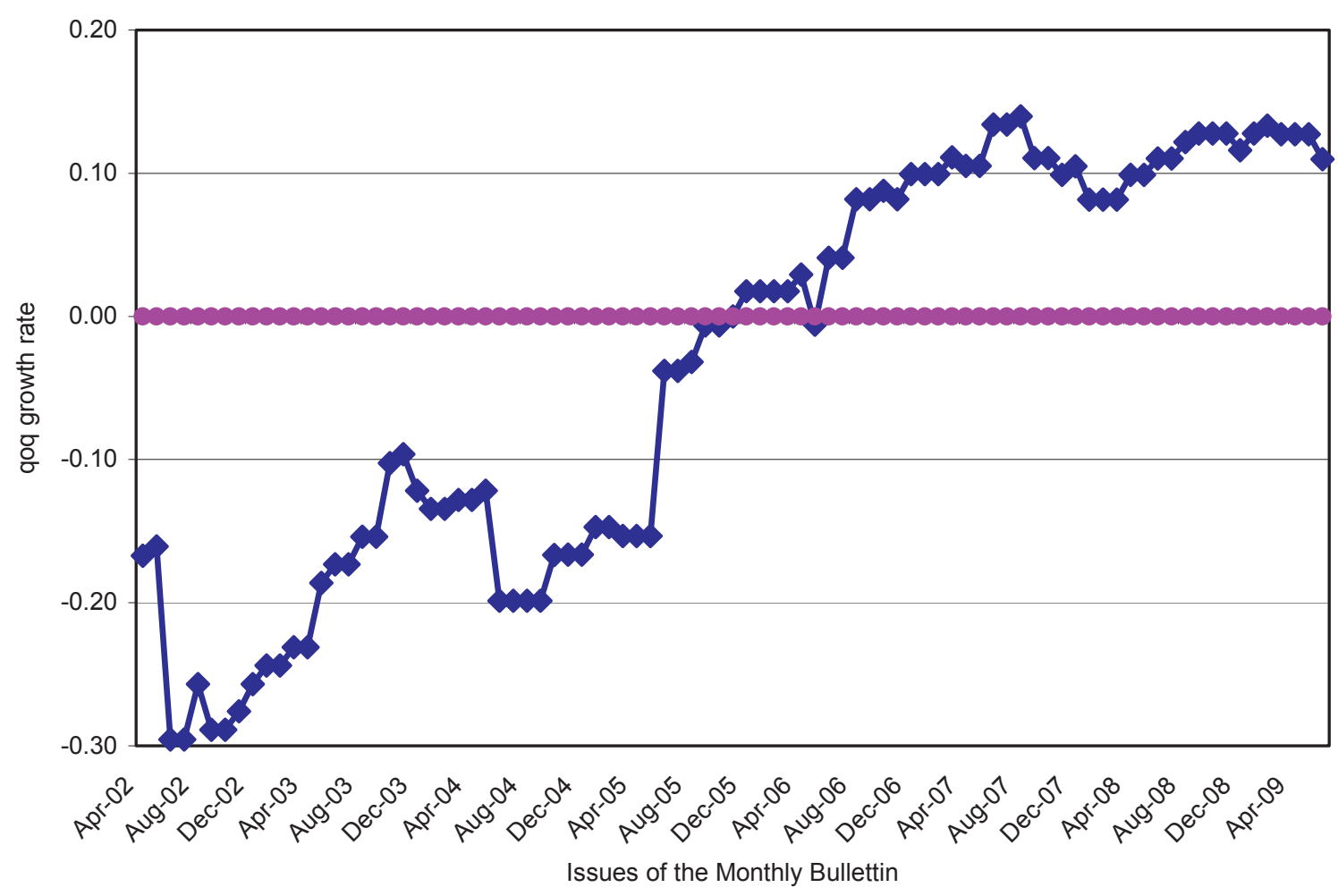

This Figure shows the evolution of the GDP annual growth rate for the fourth quarter of 2001 through different vintages. For each vintage, corresponding to an issue of the monthly bulletin, we have a different value of the GDP annual growth rate for the fourth quarter of 2001. 
Figure 3a: Revisions for GDP growth (yoy) - euro area, US and Japan data.

GDP

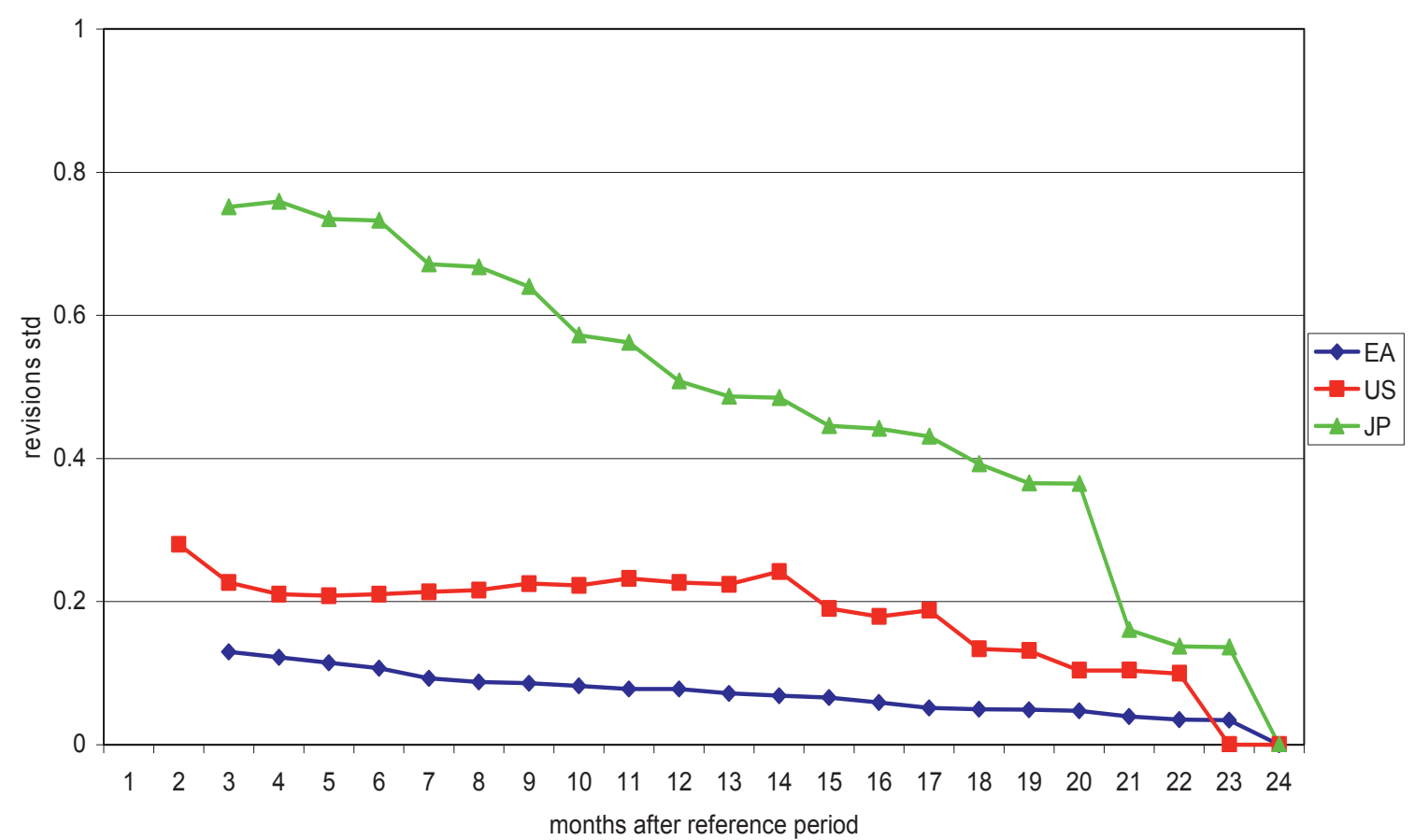

In this figure we compare the ratio of the standard deviation of revisions on the standard deviation of the respective series for the GDP annual growth rate of the Euro Area, the U.S. and Japan. The standard deviation of the series is computed on the last available vintage, i.e. June 2009. The revisions are defined as $\mathrm{Y}(\mathrm{t} \mid \mathrm{t}+\mathrm{i})-\mathrm{Y}(\mathrm{t} \mid \mathrm{t}+24)$, where $\mathrm{t}$ indicates the reference period, while $\mathrm{t}+\mathrm{i}-$ for $\mathrm{i}=1,2, \ldots 24$ on the category axis - is the time in which the value of the series is observed and we consider the observation available two years later - Y $(\mathrm{tlt}+24)$ - the "true value". 
Figure 3b: Revisions for HICP inflation (yoy) - euro area, US and Japan data.

HICP

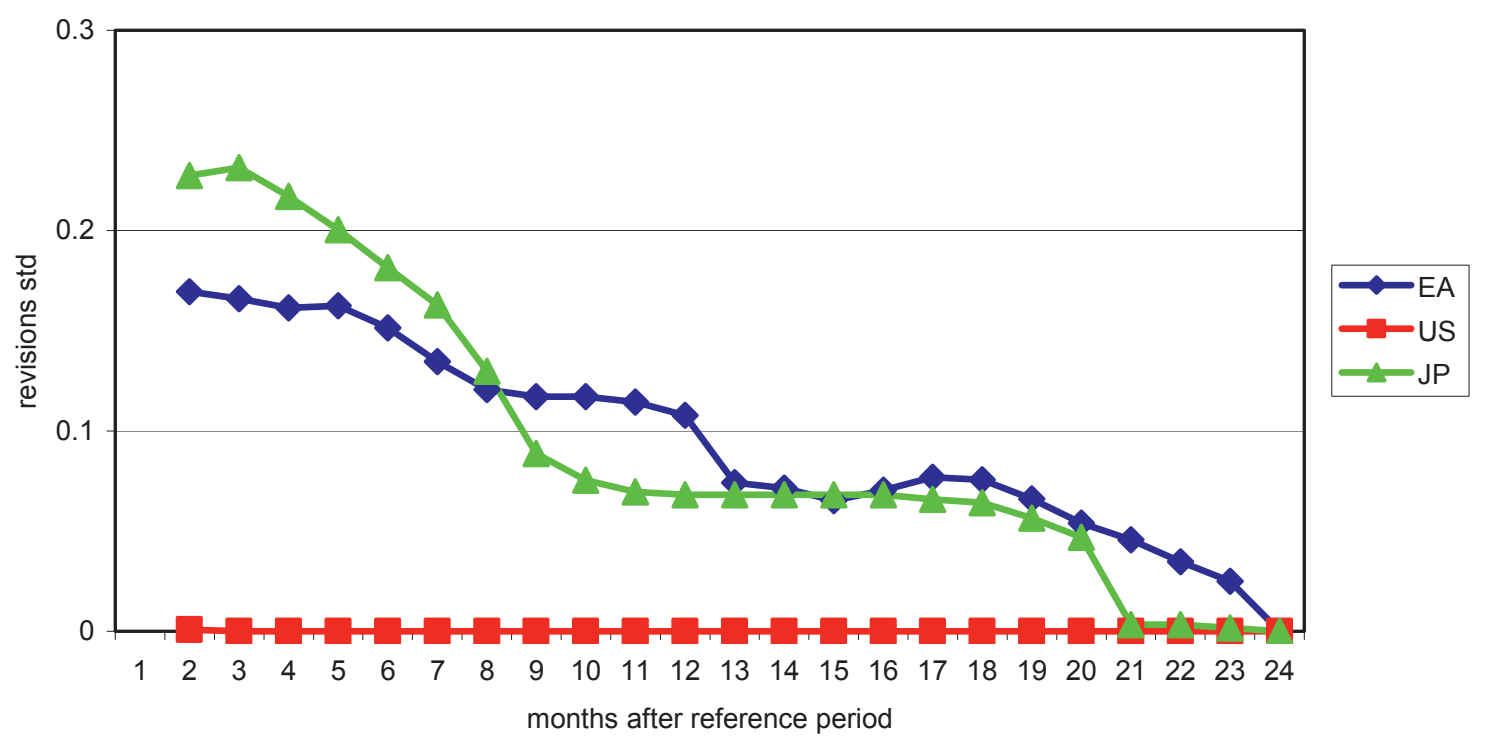

In this figure we compare the ratio of the standard deviation of revisions on the standard deviation of the respective series for the annual inflation of the Euro Area, the U.S. and Japan. The standard deviation of the series is computed on the last available vintage, i.e. June 2009. The revisions are defined as $\mathrm{Y}(\mathrm{t} \mid \mathrm{t}+\mathrm{i})-\mathrm{Y}(\mathrm{t} \mid \mathrm{t}+24)$, where $\mathrm{t}$ indicates the reference period, while $\mathrm{t}+\mathrm{i}-$ for $\mathrm{i}=1,2, \ldots 24$ on the category axis - is the time in which the value of the series is observed and we consider the observation available two years later - Y(tlt+24) - the "true value". 
Figure 3c: Revisions IP growth (yoy) - euro area, US and Japan data.

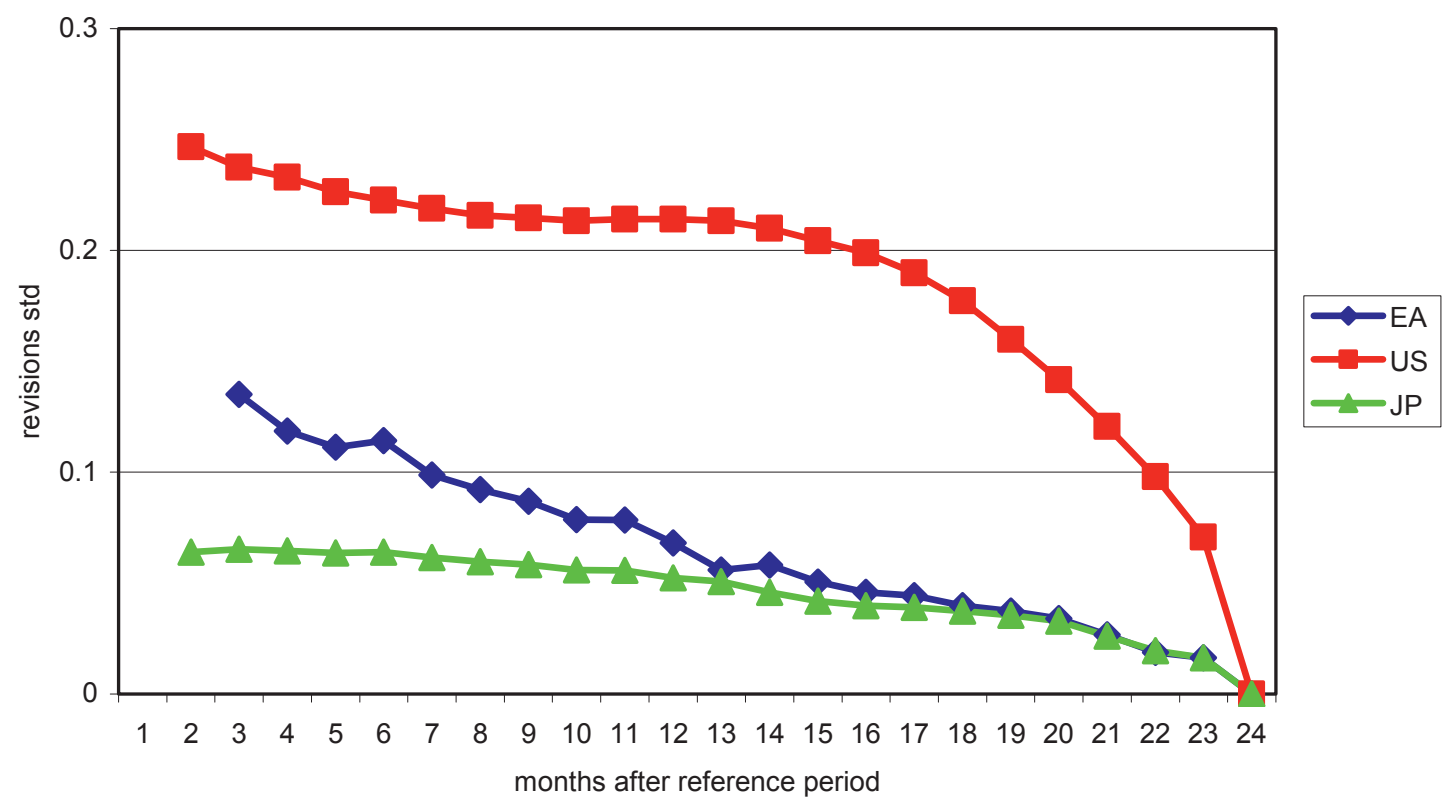

In this figure we compare the ratio of the standard deviation of revisions on the standard deviation of the respective series for the Industrial Production annual growth rate of the Euro Area, the U.S. and Japan. The standard deviation of the series is computed on the last available vintage, i.e. June 2009. The revisions are defined as $\mathrm{Y}(\mathrm{t} \mid \mathrm{t}+\mathrm{i})-\mathrm{Y}(\mathrm{t} t \mathrm{t}+24)$, where $\mathrm{t}$ indicates the reference period, while $\mathrm{t}+\mathrm{i}-$ for $\mathrm{i}=1,2, \ldots 24$ on the category axis - is the time in which the value of the series is observed and we consider the observation available two years later - Y(t|t+24) - the "true value". 
Figure 3d: Revisions Unemployment rate - euro area, US and Japan data.

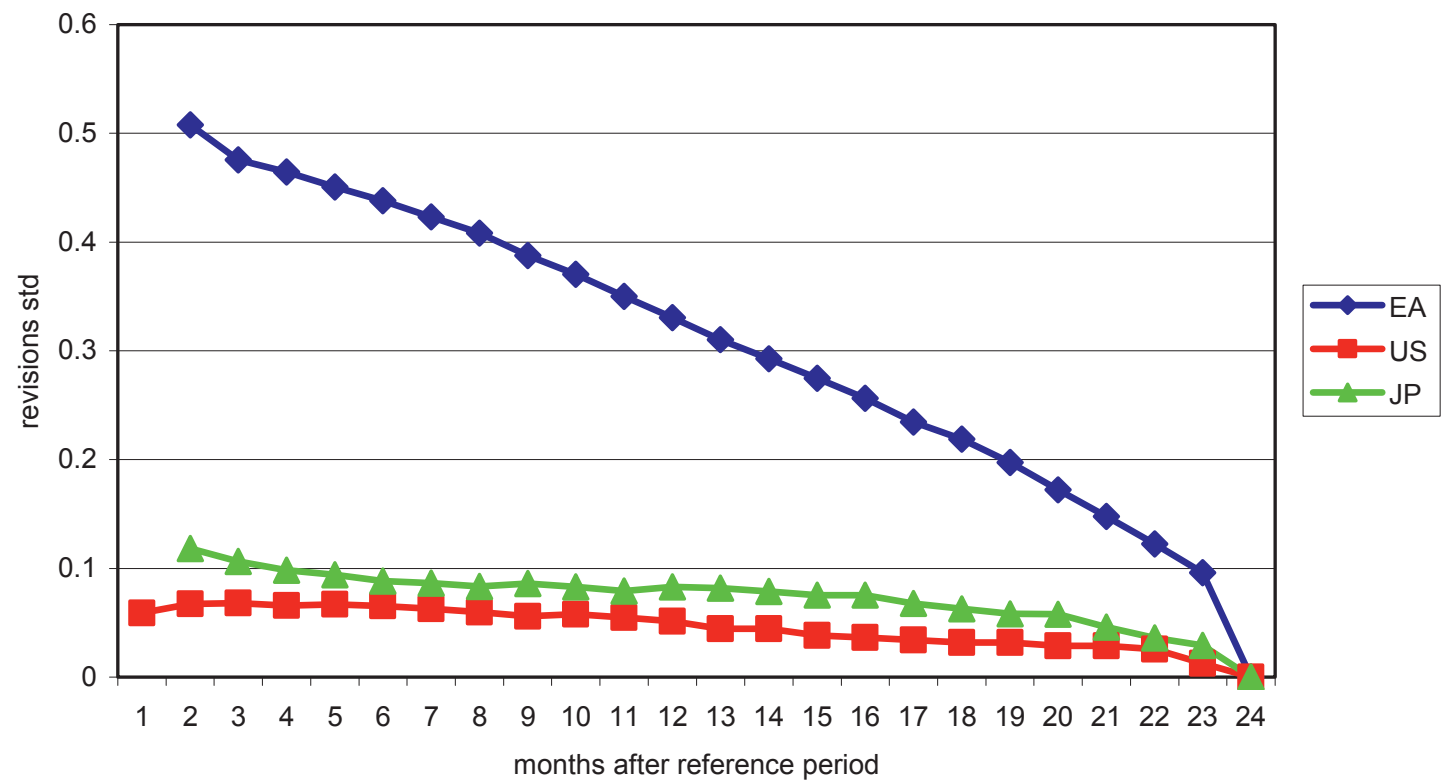

In this figure we compare the ratio of the standard deviation of revisions on the standard deviation of the respective series for the Unemployment of the Euro Area, the U.S. and Japan. The standard deviation of the series is computed on the last available vintage, i.e. June 2009. The revisions are defined as $\mathrm{Y}(\mathrm{t} \mid \mathrm{t}+\mathrm{i})-\mathrm{Y}(\mathrm{t} \mid \mathrm{t}+24)$, where $\mathrm{t}$ indicates the reference period, while $\mathrm{t}+\mathrm{i}-\mathrm{for} \mathrm{i}=1,2, \ldots .24$ on the category axis - is the time in which the value of the series is observed and we consider the observation available two years later - Y(ttt+24) - the "true value". 
Figure 4a: Vintages for Apparent labour productivity growth (yoy).

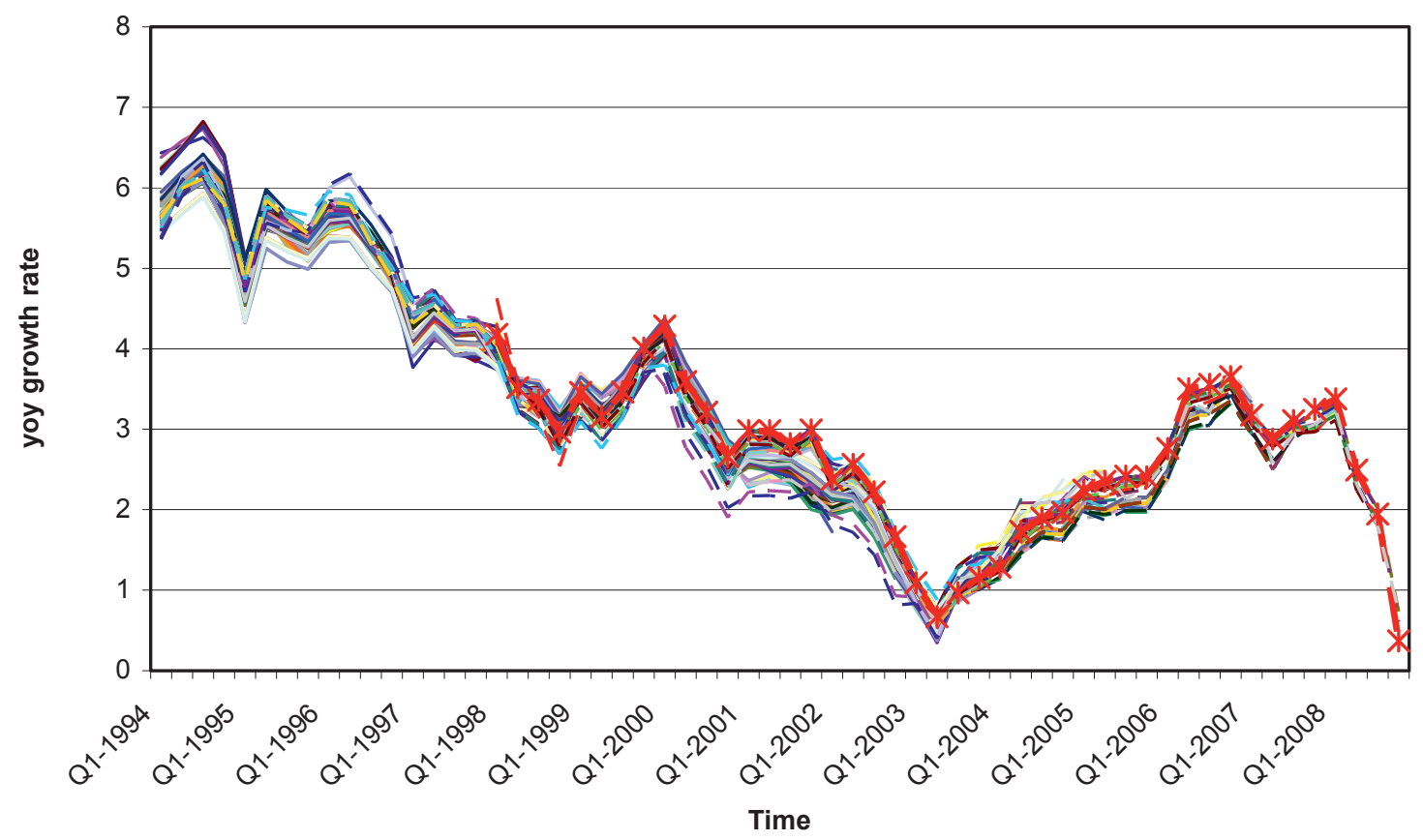

This Figure shows the evolution of the Apparent labour productivity through vintages. The different lines are the plots of the Apparent labour productivity series for all the available vintages. At each point in time each plot indicates the value of the Apparent labour productivity relative to that point in time, but for a different vintage. The crosses indicate the last observation in each vintage. 
Figure 4b: Vintages for Propensity to consume.

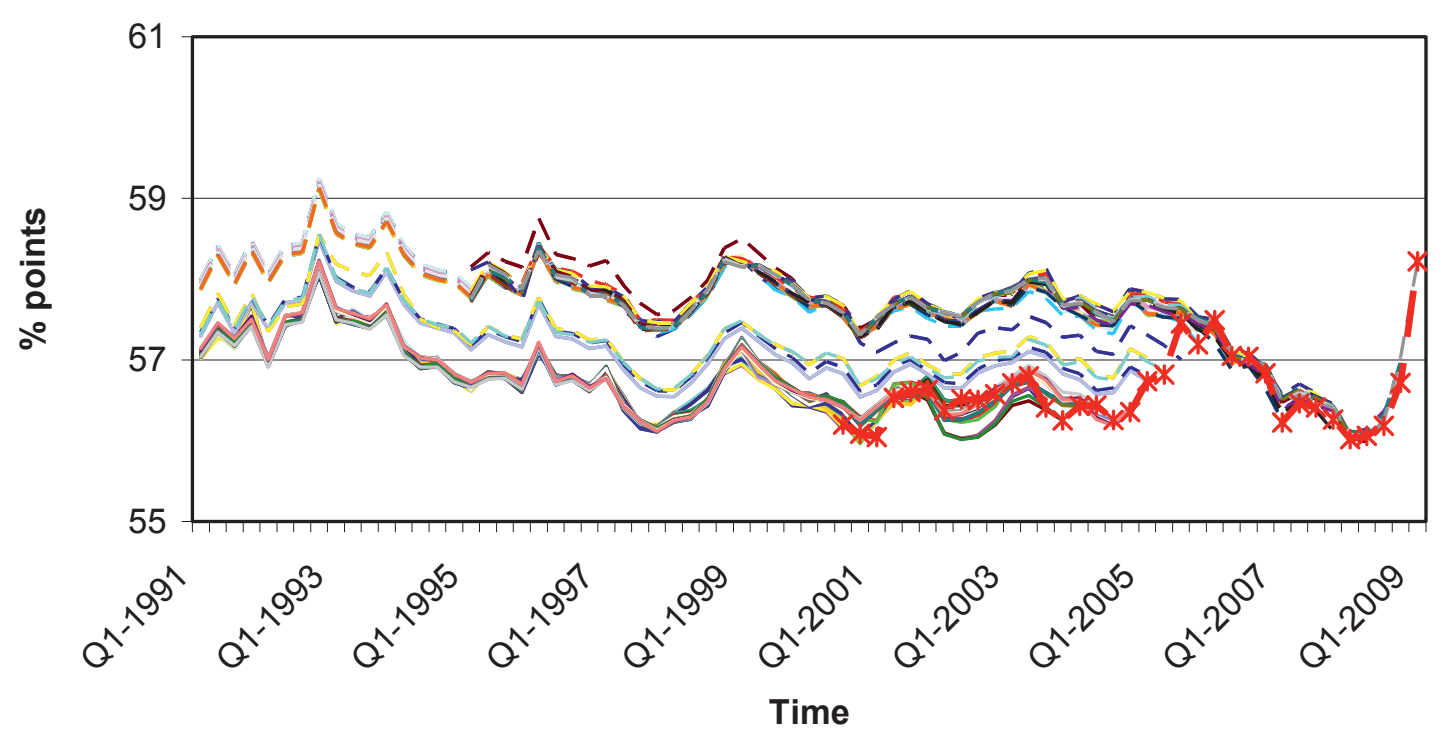

This Figure shows the evolution of the Propensity to consume through vintages. The different lines are the plots of the Propensity to consume series for all the available vintages. At each point in time each plot indicates the value of the Propensity to consume relative to that point in time, but for a different vintage. The crosses indicate the last observation in each vintage. 
Figure 4c: Vintages for Propensity to invest.

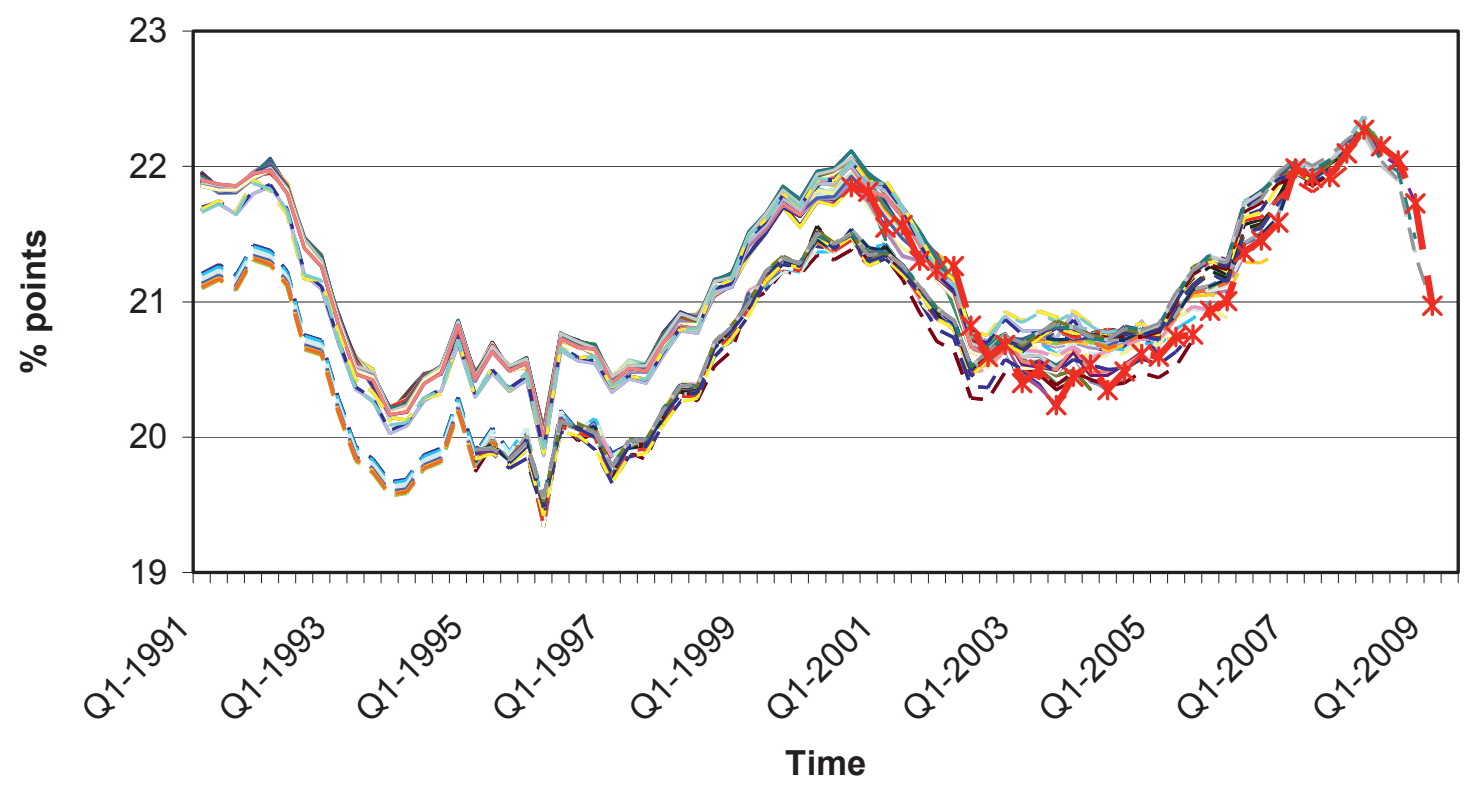

This Figure shows the evolution of the Propensity to invest through vintages. The different lines are the plots of the Propensity to invest series for all the available vintages. At each point in time each plot indicates the value of the Propensity to invest relative to that point in time, but for a different vintage. The crosses indicate the last observation in each vintage. 
Figure 4d: Vintages for Internal terms of trade.

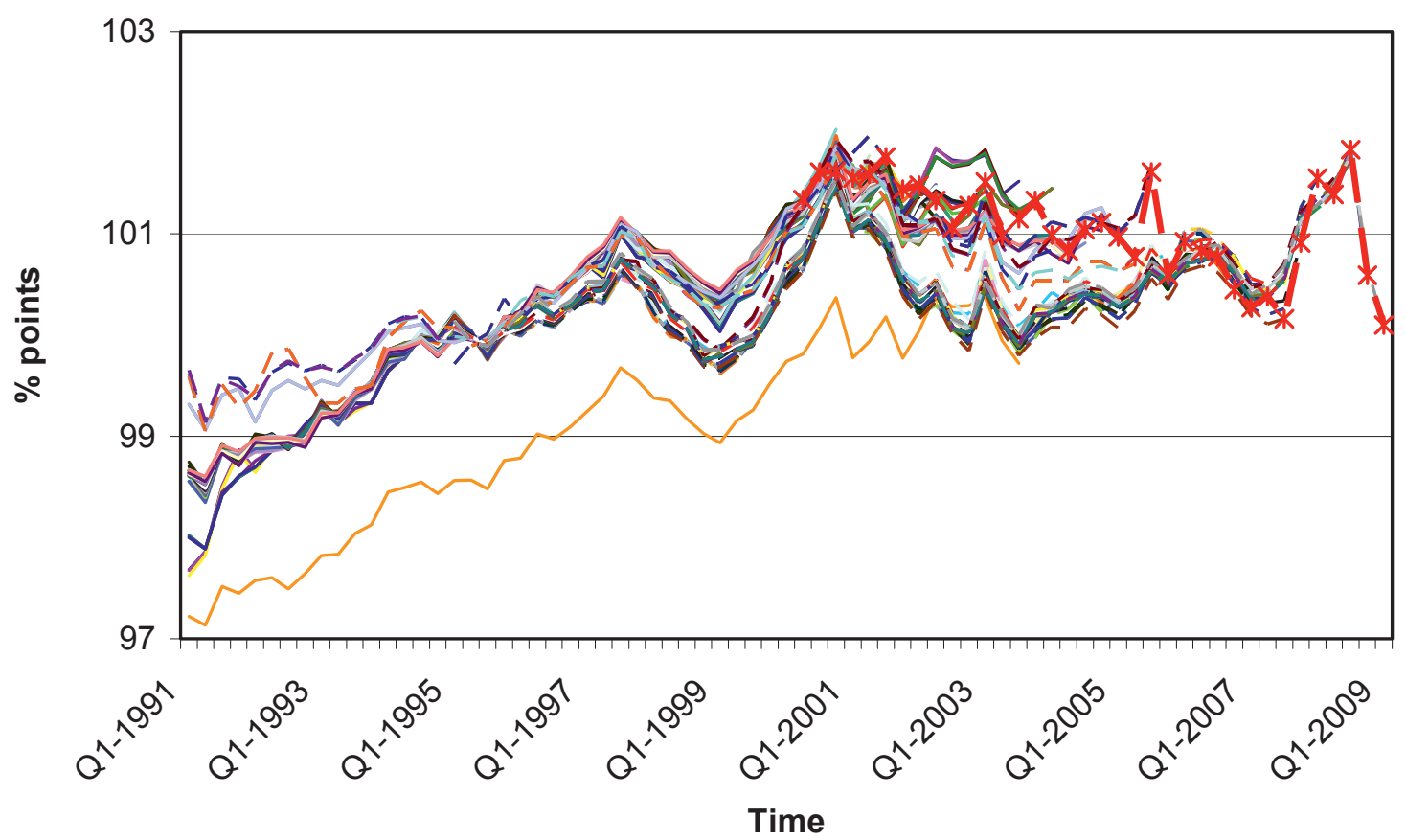

This Figure shows the evolution of the Internal terms of trade through vintages. The different lines are the plots of the Internal terms of trade series for all the available vintages. At each point in time each plot indicates the value of the Internal terms of trade relative to that point in time, but for a different vintage. The crosses indicate the last observation in each vintage. 
Figure 4e: Vintages for Trade openness.

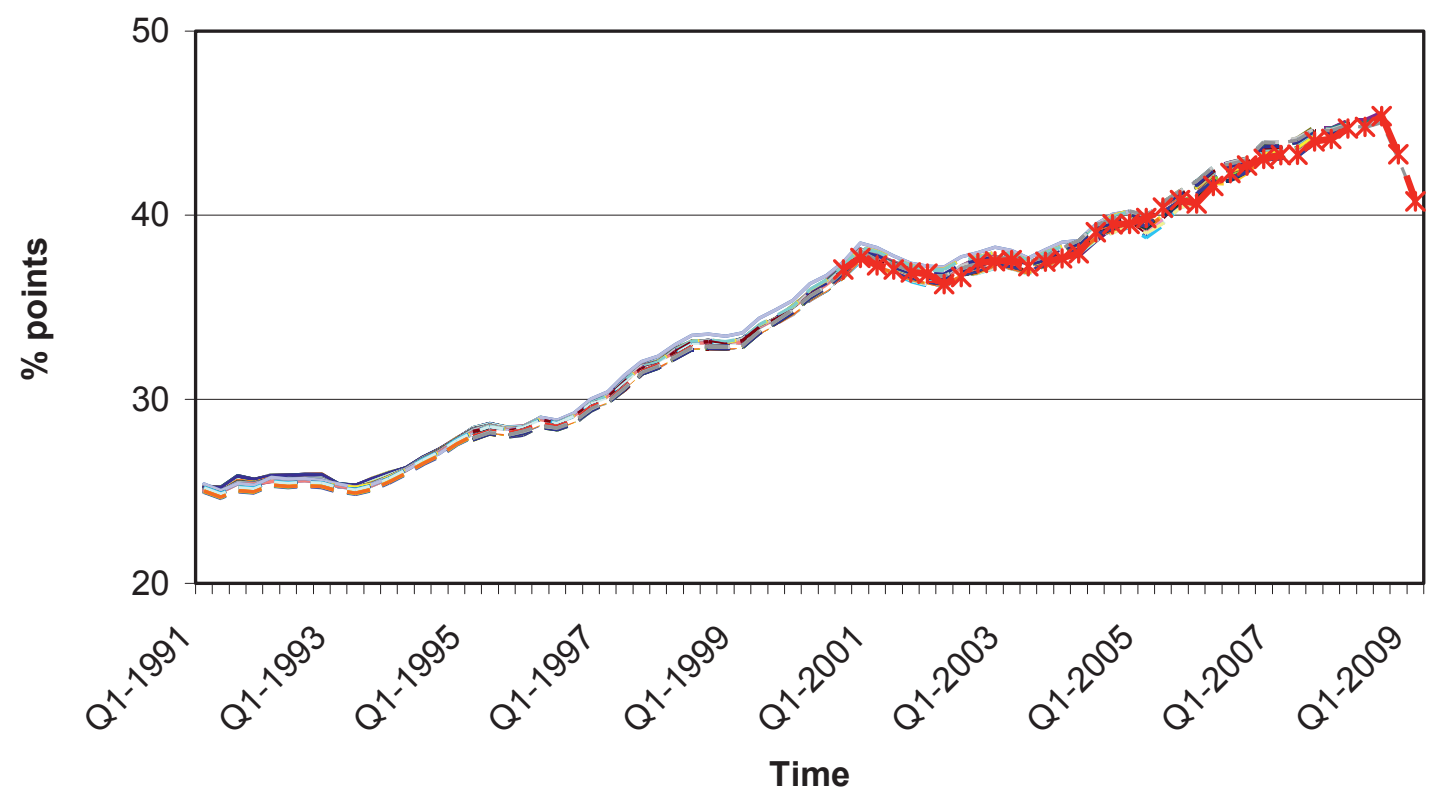

This Figure shows the evolution of the Trade openness through vintages. The different lines are the plots of the Trade openness of trade series for all the available vintages. At each point in time each plot indicates the value of the Trade openness of trade relative to that point in time, but for a different vintage. The crosses indicate the last observation in each vintage. 
Figure 5: Real-time euro area NAIRU.

$\longrightarrow$ RT NAIRU — - Last NAIRU —Pseudo RT NAIRU $-90 \%$ c.i.

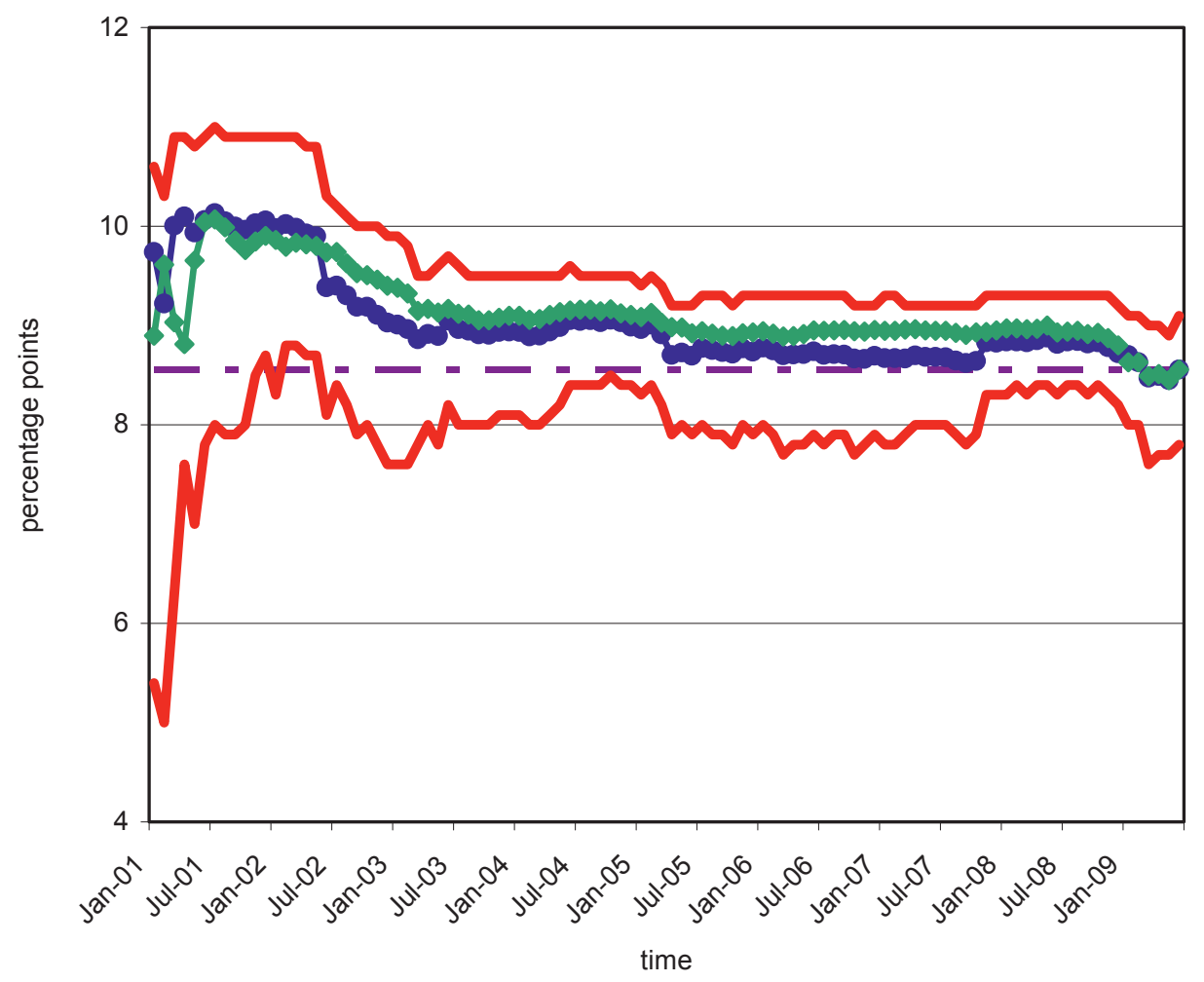

This figure reports the evolution of the NAIRU computed in real time along with the associated confidence interval, the NAIRU estimated with the pseudo real time exercise, and the NAIRU computed with the last available vintage (denoted "Last NAIRU"). At each point in time, each plot indicates the value of the variables relative to that point in time, but for a different vintage. 
Figure 6: Unemployment gap in real time

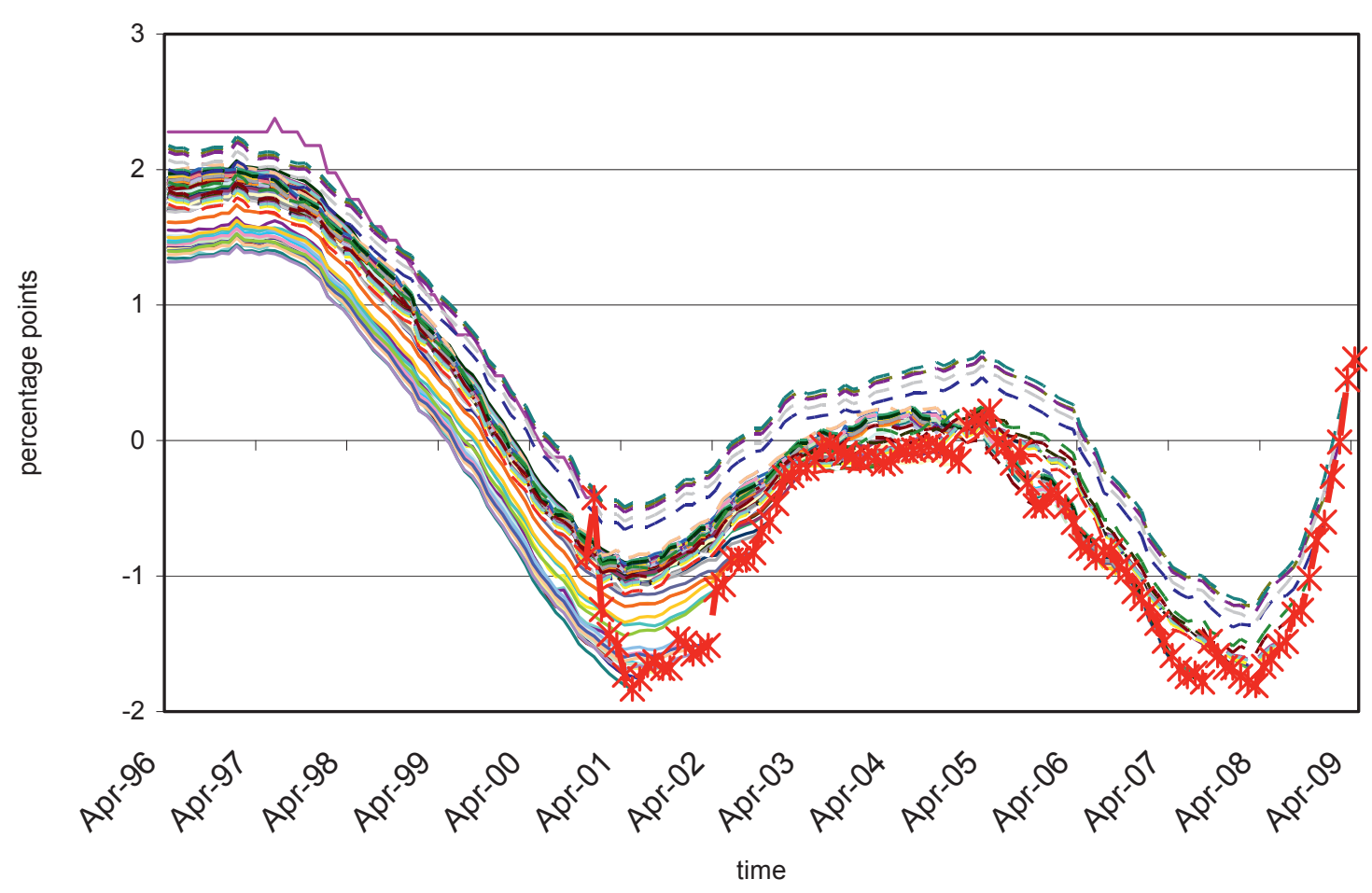

This Figure shows the evolution of the unemployment gap, defined as unemployment rate minus NAIRU, through vintages. The different lines are the plots of the unemployment gap series for all the available vintages. At each point in time each plot indicates the value of the unemployment gap relative to that point in time, but for a different vintage. The crosses indicate the last observation in each vintage. 
Annex 1: Cut-off dates

\begin{tabular}{|c|c|c|}
\hline Vintage & Cut-off date & GC meeting \\
\hline Jan-01 & 03-Jan-01 & 04-Jan-01 \\
\hline Feb-01 & 31-Jan-01 & 01-Feb-01 \\
\hline Mar-01 & 28-Feb-01 & 01-Mar-01 \\
\hline Apr-01 & 10-Apr-01 & 11-Apr-01 \\
\hline May-01 & 08-May-01 & 10-May-01 \\
\hline Jun-01 & 06-Jun-01 & 07-Jun-01 \\
\hline Jul-01 & 04-Jul-01 & 05-Jul-01 \\
\hline Aug-01 & 01-Aug-01 & 02-Aug-01 \\
\hline Sep-01 & 13-Sep-01 & 13-Sep-01 \\
\hline Oct-01 & 10-Oct-01 & 11-Oct-01 \\
\hline Nov-01 & 07-Nov-01 & 08-Nov-01 \\
\hline Dec-01 & 05-Dec-01 & 06-Dec-01 \\
\hline Jan-02 & 16-Jan-02 & 17-Jan-02 \\
\hline Feb-02 & 06-Feb-02 & 07-Feb-02 \\
\hline Mar-02 & 06-Mar-02 & 07-Mar-02 \\
\hline Apr-02 & 03-Apr-02 & 04-Apr-02 \\
\hline Мay-02 & 30-Apr-02 & 02-Мay-02 \\
\hline Jun-02 & 05-Jun-02 & 06-Jun-02 \\
\hline Jul-02 & 03-Jul-02 & 04-Jul-02 \\
\hline Aug-02 & 31-Jul-02 & 01-Aug-02 \\
\hline Sep-02 & 11-Sep-02 & 12-Sep-02 \\
\hline Oct-02 & 09-Oct-02 & $10-$ Oct-02 \\
\hline Nov-02 & 06-Nov-02 & 07-Nov-02 \\
\hline Dec-02 & 04-Dec-02 & 05-Dec-02 \\
\hline Jan-03 & 15-Jan-03 & 23-Jan-03 \\
\hline Feb-03 & 05-Feb-03 & 06-Feb-03 \\
\hline Mar-03 & 05-Mar-03 & 06-Mar-03 \\
\hline Apr-03 & 02-Apr-03 & 03-Apr-03 \\
\hline May-03 & 07-May-03 & 08-May-03 \\
\hline Jun-03 & 04-Jun-03 & 05-Jun-03 \\
\hline Jul-03 & 09-Jul-03 & 10-Jul-03 \\
\hline Aug-03 & 30-Jul-03 & 31-Jul-03 \\
\hline Sep-03 & 03-Sep-03 & 04-Sep-03 \\
\hline Oct-03 & 01-Oct-03 & 02-Oct-03 \\
\hline Nov-03 & 05-Nov-03 & 06-Nov-03 \\
\hline Dec-03 & 03-Dec-03 & 04-Dec-03 \\
\hline Jan-04 & 14-Jan-04 & 22-Jan-04 \\
\hline Feb-04 & 04-Feb-04 & 05-Feb-04 \\
\hline Mar-04 & 03-Mar-04 & 04-Mar-04 \\
\hline Apr-04 & 31-Mar-04 & 01-Apr-04 \\
\hline May-04 & 05-May-04 & 06-May-04 \\
\hline Jun-04 & 02-Jun-04 & 03-Jun-04 \\
\hline Jul-04 & 30-Jun-04 & 01-Jul-04 \\
\hline Aug-04 & 04-Aug-04 & 05-Aug-04 \\
\hline Sep-04 & 01-Sep-04 & 02-Sep-04 \\
\hline Oct-04 & 06-Oct-04 & 07-Oct-04 \\
\hline Nov-04 & 03-Nov-04 & 04-Nov-04 \\
\hline Dec-04 & 01-Dec-04 & 02-Dec-04 \\
\hline Jan-05 & 12-Jan-05 & 13-Jan-05 \\
\hline Feb-05 & 02-Feb-05 & 03-Feb-05 \\
\hline Mar-05 & 02-Mar-05 & 03-Mar-05 \\
\hline
\end{tabular}

\begin{tabular}{|c|c|c|}
\hline Vintage & Cut-off date & GC meeting \\
\hline Apr-05 & 06-Apr-05 & 07-Apr-05 \\
\hline May-05 & 03-May-05 & 04-May-05 \\
\hline Jun-05 & 01-Jun-05 & 02-Jun-05 \\
\hline Jul-05 & 06-Jul-05 & 07-Jul-05 \\
\hline Aug-05 & 03-Aug-05 & 04-Aug-05 \\
\hline Sep-05 & 31-Aug-05 & 01-Sep-05 \\
\hline Oct-05 & $05-$-Oct- 05 & 06-Oct-05 \\
\hline Nov-05 & 02-Nov-05 & 03-Nov-05 \\
\hline Dec-05 & 30-Nov-05 & 01-Dec-05 \\
\hline Jan-06 & 11-Jan-06 & 12-Jan-06 \\
\hline Feb-06 & 01-Feb-06 & 02-Feb-06 \\
\hline Mar-06 & 01-Mar-06 & 02-Mar-06 \\
\hline Apr-06 & 04-Apr-06 & 06-Apr-06 \\
\hline May-06 & 03-May-06 & 04-May-06 \\
\hline Jun-06 & 07-Jun-06 & 08-Jun-06 \\
\hline Jul-06 & 05-Jul-06 & 06-Jul-06 \\
\hline Aug-06 & 02-Aug-06 & 03-Aug-06 \\
\hline Sep-06 & 30-Aug-06 & 31-Aug-06 \\
\hline Oct-06 & 04-Oct-06 & $05-O c t-06$ \\
\hline Nov-06 & 31-Oct-06 & 02-Nov-06 \\
\hline Dec-06 & 06-Dec-06 & 07-Dec-06 \\
\hline Jan-07 & 10-Jan-07 & 11-Jan-07 \\
\hline Feb-07 & 07-Feb-07 & 08-Feb-07 \\
\hline Mar-07 & 07-Mar-07 & 08-Mar-07 \\
\hline Apr-07 & 11-Apr-07 & 12-Apr-07 \\
\hline Мay-07 & 08-May-07 & 10-May-07 \\
\hline Jun-07 & 05-Jun-07 & 06-Jun-07 \\
\hline Jul-07 & 04-Jul-07 & 05-Jul-07 \\
\hline Aug-07 & 01-Aug-07 & 02-Aug-07 \\
\hline Sep-07 & 05-Sep-07 & 06-Sep-07 \\
\hline Oct-07 & 02-Oct-07 & 04-Oct-07 \\
\hline Nov-07 & 07-Nov-07 & 08-Nov-07 \\
\hline Dec-07 & 05-Dec-07 & 06-Dec-07 \\
\hline Jan-08 & 09-Jan-08 & 10-Jan-08 \\
\hline Feb-08 & 06-Feb-08 & 06-Mar-08 \\
\hline Mar-08 & 05-Mar-08 & 06-Mar-08 \\
\hline Apr-08 & 09-Apr-08 & 10-Apr-08 \\
\hline May-08 & 06-Мay-08 & 08-May-08 \\
\hline Jun-08 & 04-Jun-08 & 05-Jun-08 \\
\hline Jul-08 & 02-Jul-08 & 03-Jul-08 \\
\hline Aug-08 & 06-Aug-08 & 07-Aug-08 \\
\hline Sep-08 & 03-Sep-08 & 04-Sep-08 \\
\hline Oct-08 & $30-$ Sep-08 & 02-Oct-08 \\
\hline Nov-08 & 05-Nov-08 & 06-Nov-08 \\
\hline Dec-08 & 03-Dec-08 & 04-Dec-08 \\
\hline Jan-09 & 14-Jan-09 & 15-Jan-09 \\
\hline Feb-09 & 04-Feb-09 & 05-Feb-09 \\
\hline Mar-09 & 04-Mar-09 & 05-Mar-09 \\
\hline Apr-09 & 01-Apr-09 & 02-Apr-09 \\
\hline May-09 & 06-May-09 & 07-Мay-09 \\
\hline Jun-09 & 03-Jun-09 & 04-Jun-09 \\
\hline
\end{tabular}




\section{Annex 2: Core series list}

$\begin{array}{ll}\text { IPP } & \text { Industrial Producer Prices } \\ \text { Ulc } & \text { Unit Labour Cost } \\ \text { Lnn } & \text { Employment, total } \\ \text { Yed } & \text { GDP deflator } \\ \text { Ddd } & \text { Domestic demand deflator } \\ \text { Pcd } & \text { Consumption deflator } \\ \text { Gcd } & \text { Government consumption deflator } \\ \text { Itd } & \text { Investment deflator } \\ \text { Xtd } & \text { Exports deflator } \\ \text { mtd } & \text { Imports deflator } \\ \text { yen } & \text { GDP, nominal } \\ \text { Pcn } & \text { Consumption, nominal } \\ \text { Gcn } & \text { Government consumption, nominal } \\ \text { Itn } & \text { Investment, nominal } \\ \text { Cin } & \text { Changes in inventories, nominal } \\ \text { Xtn } & \text { Exports, nominal } \\ \text { Mtn } & \text { Imports, nominal } \\ \text { Yer } & \text { GDP, real } \\ \text { Pcr } & \text { Consumption, real } \\ \text { Gcr } & \text { Government consumption, real } \\ \text { Itr } & \text { Investment, real } \\ \text { Cir } & \text { Changes in inventories, real } \\ \text { Xtr } & \text { Exports, real } \\ \text { Mtr } & \text { Imports, real } \\ \text { ipSA } & \text { Industrial production, total } \\ \text { Unrx } & \text { Unemployment rate } \\ \text { Hicp } & \text { Harmonized index of consumer prices } \\ \text { Can } & \text { Current account balance } \\ \text { gbr10y } & \text { 10-years government bond } \\ \text { ir3m } & \text { 3-month Euribor } \\ \text { Sei } & \text { Stock exchange index } \\ \text { M3 } & \text { M3 } \\ \text { M1 } & \text { M1 } \\ \text { Bm } & \text { Base money } \\ \text { Tloa } & \text { Loans, total } \\ \text { Tcre } & \text { Credit, total } \\ \text { Hlc } & \text { Hourly labour cost: by components and by economic activity } \\ \text { Psd } & \text { Public sector deficit } \\ \end{array}$




\section{Annex 3: Detailed description of individual variables included in the dataset}

The annex follows the organisation of the CSV files, i.e. it is divided into 3 main blocks: annual, quarterly and monthly. Variables within each block are marked with a letter indicating in which column of the file the variable is published ${ }^{1}$.

This annex describes the status of the database as it was at the time of preparing the paper (i.e. up to June 2009). The documentation is, however, regularly updated following the updates of the dataset and its most up-to-date version can be downloaded from the ECB Statistical Data Warehouse, the Explanation page dedicated to RTDB dataset. 


\section{Overview of monthly indicators}

\begin{tabular}{|l|l|}
\hline $\begin{array}{c}\text { Columns in } \\
\text { the files }\end{array}$ & \multicolumn{1}{c|}{ Block name } \\
\hline B-M & Industrial production: by industry \\
\hline N-W & Retail sales: by type of goods \\
\hline X-AG & Unemployment and unemployment rate: by gender and by age \\
\hline AH-AV & HICP \\
\hline AW-BI & $\begin{array}{l}\text { External transactions and position: current and capital account, by } \\
\text { credit and debt }\end{array}$ \\
\hline BJ-BN & Exchange rates: effective exchange rates \\
\hline BO-DA & Trade in goods: value, volume and unit value by product group \\
\hline DB-DH & $\begin{array}{l}\text { Interest rate, money market overnight, 1 to 12 months, US and Japan } \\
\text { 3 months }\end{array}$ \\
\hline DI-DO & Government bond yield 2, 3, 5, 7, 10 years, US and Japan, 10 years \\
\hline DP-EC & $\begin{array}{l}\text { Dow Jones EURO STOXX indices by economics sectors, S\&P and } \\
\text { Nikkei }\end{array}$ \\
\hline ED-EL & US and Japan: main economic and financial indicators \\
\hline EM-EY & Industry and commodity prices: by type of goods and by industry \\
\hline EZ-FF & $\begin{array}{l}\text { Money supply M1 M2 M3, Base money, Total loans, Total credit } \\
\text { (seasonally adjusted }\end{array}$ \\
\hline FG-FM & $\begin{array}{l}\text { Money supply M1 M2 M3, Base money, Total loans, Total credit (not } \\
\text { seasonally adjusted) }\end{array}$ \\
\hline FN-GH & $\begin{array}{l}\text { Confidence indicators: economic, manufacturing, consumer, } \\
\text { construction, retail trade, services }\end{array}$ \\
\hline
\end{tabular}




\section{Industrial production: by industry}

B Total (annual percentage changes)

C Total (index)

D Total (annual percentage changes)

Industry excluding constructions and energy-

E Total (annual percentage changes)

F Intermediate goods

G Capital goods

H Consumer goods- Total (annual percentage changes)

I

Durable

J Energy

Non-Durable

L Construction

M Manufacturing

\section{EURO AREA CONCEPT}

Since February 2009: Euro 16

April 2008 to January 2009: Euro 15

April 2007 to March 2008: Euro 13

January 2004 to March 2007: Euro 12

January 2001 to December 2003: Euro area changing composition

SEASONAL ADJUSTMENT

Data working day adjusted, non-seasonally adjusted (unless otherwise indicated)

\section{ADDITIONAL NOTES}

- Data on industry excluding constructions includes energy until August 2001 and excludes energy afterwards.

- Change of a base year from 1995 to 2000 in July 2003

- Methodological notes on the ECB's website: http://www.ecb.int/stats/prices/accounts/html/index.en.html

SOURCE: Eurostat

\section{$\mathrm{B}$}

\begin{tabular}{|l|l|}
\hline Name & Industrial Production Index, Total Industry \\
\hline Units & $\begin{array}{l}\text { Since January 2004 data available as index, } \\
\text { June 2001 to December 2003 data available as annual percentage } \\
\text { changes, } \\
\text { January 2001 to May 2001 data available as index. }\end{array}$ \\
\hline
\end{tabular}


C

\begin{tabular}{|l|l|}
\hline Name & $\begin{array}{l}\text { Industrial Production Index, Total Industry (excluding } \\
\text { construction) }\end{array}$ \\
\hline Units & Data available as index \\
\hline Adjustment & Seasonally adjusted \\
\hline
\end{tabular}

D

\begin{tabular}{|l|l|}
\hline Name & $\begin{array}{l}\text { Industrial Production Index, Total Industry (excluding } \\
\text { construction) }\end{array}$ \\
\hline Units & $\begin{array}{l}\text { Since January 2004 data available as index, } \\
\text { June } 2001 \text { to December } 2003 \text { data available as annual percentage } \\
\text { changes, } \\
\text { January 2001 to May 2001 data available as index. }\end{array}$ \\
\hline
\end{tabular}

E

\begin{tabular}{|l|l|}
\hline Name & $\begin{array}{l}\text { Industrial Production Index, Total Industry excluding construction } \\
\text { and MIG Energy }\end{array}$ \\
\hline Units & $\begin{array}{l}\text { Since January 2004 data available as index, } \\
\text { August } 2001 \text { to December } 2003 \text { data available as annual percentage } \\
\text { changes }\end{array}$ \\
\hline Availability & Published since August 2001 \\
\hline
\end{tabular}

F

\begin{tabular}{|l|l|}
\hline Name & Industrial Production Index, MIG Intermediate Goods Industry \\
\hline Units & $\begin{array}{l}\text { Since January 2004 data available as index; } \\
\text { June 2001 to December 2003 data available as annual percentage } \\
\text { changes, } \\
\text { January 2001 to May 2001 data available as index. }\end{array}$ \\
\hline Comments & $\begin{array}{l}\text { Including energy prior to August 2001 (part of manufacturing), } \\
\text { excluding energy afterwards. }\end{array}$ \\
\hline
\end{tabular}

G

\begin{tabular}{|l|l|}
\hline Name & Industrial Production Index, MIG Capital Goods Industry \\
\hline Units & $\begin{array}{l}\text { Since January 2004 data available as index; } \\
\text { June 2001 to December 2003 data available as annual percentage } \\
\text { changes, } \\
\text { January 2001 to May 2001 data available as index. }\end{array}$ \\
\hline Comments & $\begin{array}{l}\text { Including energy prior to August 2001 (part of manufacturing), } \\
\text { excluding energy afterwards. }\end{array}$ \\
\hline
\end{tabular}

$\mathrm{H}$

\begin{tabular}{|l|l|}
\hline Name & Industrial Production Index, Consumer goods industry \\
\hline Units & $\begin{array}{l}\text { Since January 2004 data available as index; } \\
\text { June 2001 to December } 2003 \text { data available as annual percentage } \\
\text { changes, } \\
\text { March 2001 to May 2001 data available as index }\end{array}$ \\
\hline Comments & $\begin{array}{l}\text { Prior to March 2001 the series calculated as } \\
\left(0.843^{*} \text { STS.M.U2.W.PROD.NS0060.4.000)+ }\right. \\
(0.157 * \text { STS.M.U2.W.PROD.NS0070.4.000); values of these two series }\end{array}$ \\
\hline
\end{tabular}




\begin{tabular}{|l|l|}
\hline & $\begin{array}{l}\text { can be found in columns I \& J; } \\
\text { Including energy prior to August } 2001 \text { (part of manufacturing), } \\
\text { excluding energy afterwards }\end{array}$ \\
\hline Availability & Since March 2001 \\
\hline
\end{tabular}

\section{I}

\begin{tabular}{|l|l|}
\hline Name & $\begin{array}{l}\text { Industrial Production Index, MIG Durable Consumer Goods } \\
\text { Industry }\end{array}$ \\
\hline Units & $\begin{array}{l}\text { Since January 2004 data available as index, } \\
\text { June 2001 to December 2003 data available as annual percentage } \\
\text { changes, } \\
\text { January 2001 to May 2001 data available as index. }\end{array}$ \\
\hline Comments & $\begin{array}{l}\text { Including energy prior to August 2001 (part of manufacturing), } \\
\text { excluding energy afterwards. }\end{array}$ \\
\hline
\end{tabular}

J

\begin{tabular}{|l|l|}
\hline Name & $\begin{array}{l}\text { Industrial Production Index, MIG Non-durable Consumer Goods } \\
\text { Industry }\end{array}$ \\
\hline Units & $\begin{array}{l}\text { Since January 2004 data available as index, } \\
\text { June 2001 to December 2003 data available as annual percentage } \\
\text { changes, } \\
\text { January 2001 to May 2001 data available as index. }\end{array}$ \\
\hline Comments & $\begin{array}{l}\text { Including energy prior to August 2001 (part of manufacturing), } \\
\text { excluding energy afterwards. }\end{array}$ \\
\hline
\end{tabular}

K

\begin{tabular}{|l|l|}
\hline Name & Industrial Production Index, MIG Energy \\
\hline Units & $\begin{array}{l}\text { Since January 2004 data available as index, } \\
\text { August 2001 to December 2003 data available as annual percentage } \\
\text { changes }\end{array}$ \\
\hline Availability & Published since August 2001 \\
\hline
\end{tabular}

L

\begin{tabular}{|l|l|}
\hline Name & Industrial Production Index, Construction \\
\hline Units & $\begin{array}{l}\text { Since January 2004 data available as index, } \\
\text { June 2001 to December 2003 data available as annual percentage } \\
\text { changes, } \\
\text { January 2001 to May 2001 data available as index. }\end{array}$ \\
\hline
\end{tabular}

M

\begin{tabular}{|l|l|}
\hline Name & Industrial Production Index, Manufacturing \\
\hline Units & $\begin{array}{l}\text { Since January 2004 data available as index, } \\
\text { June 2001 to December 2003 data available as annual percentage } \\
\text { changes, } \\
\text { January 2001 to May 2001 data available as index. }\end{array}$ \\
\hline
\end{tabular}




\section{Retail sales: by type of goods}

\begin{tabular}{lc} 
& Current prices \\
N & Total (index) \\
O & Total (annual percentage changes) \\
& Constant prices: \\
P & Total (index) \\
Q & Total (annual percentage changes) \\
R & Food, beverages, tobacco \\
S & Non-food \\
T & \multicolumn{2}{c}{ Textiles, clothing, footwear } \\
U & Household equipment \\
& New passenger car registrations \\
V & \multicolumn{2}{c}{ Total (absolute value) } \\
W & Total (annual percentage changes)
\end{tabular}

EURO AREA CONCEPT

Since February 2009: Euro 16

March 2008 to January 2009: Euro 15

April 2007 to February 2008: Euro 13

January 2004 to March 2007: Euro 12

January 2001 to December 2003: Euro area changing composition

SEASONAL ADJUSTMENT

Data seasonally adjusted; unless otherwise indicated

\section{ADDITIONAL NOTES}

- Change of a base year from 1995 to 2000 in July 2003

- Methodological notes on the ECB's website: http://www.ecb.int/stats/prices/accounts/html/index.en.html

SOURCE: Eurostat except columns V and W (ECB calculations based on data from the ACEA, European Automobile Manufacturers' Association)

\begin{tabular}{|c|c|}
\hline \multicolumn{2}{|l|}{$\mathrm{N}$} \\
\hline Name & $\begin{array}{l}\text { Total Turnover Index, Retail trade, except of motor vehicles and } \\
\text { motorcycles }\end{array}$ \\
\hline \multicolumn{2}{|l|}{$\mathrm{O}$} \\
\hline Name & Current prices- Total (annual percentage changes) \\
\hline Units & $\begin{array}{l}\text { Since January } 2004 \text { data available as index, } \\
\text { June } 2001 \text { to December } 2003 \text { data available as annual percentage } \\
\text { changes, } \\
\text { January } 2001 \text { to May } 2001 \text { data available as index }\end{array}$ \\
\hline
\end{tabular}




\section{$\mathrm{P}$}

\begin{tabular}{|l|l|}
\hline Name & Total Turnover Index, deflated, Retail trade, except of motor
\end{tabular} vehicles and motorcycles

Q

\begin{tabular}{|l|l|}
\hline Name & Constant prices- Total (annual percentage changes) \\
\hline Units & $\begin{array}{l}\text { Since January 2004 data available as index } \\
\text { June 2001 to December 2003 data available as annual percentage } \\
\text { changes, } \\
\text { January 2001 to May 2001 data available as index }\end{array}$ \\
\hline
\end{tabular}

$\mathrm{R}$

\begin{tabular}{|l|l|}
\hline Name & $\begin{array}{l}\text { Total Turnover Index, deflated, Retail sale of food, beverages and } \\
\text { tobacco }\end{array}$ \\
\hline Units & $\begin{array}{l}\text { Since January 2004 data available as index, } \\
\text { June } 2001 \text { to December } 2003 \text { data available as annual percentage } \\
\text { changes, } \\
\text { January 2001 to May 2001 data available as index }\end{array}$ \\
\hline
\end{tabular}

$\mathrm{S}$

\begin{tabular}{|l|l|}
\hline Name & Total Turnover Index, deflated, Retail sale of non food products \\
\hline & Shits
\end{tabular}

Units $\quad$ Since January 2004 data available as index,

June 2001 to December 2003 data available as annual percentage changes,

January 2001 to May 2001 data available as index

$\mathrm{T}$

\begin{tabular}{|l|l|}
\hline Name & Total Turnover Index, deflated, Retail sale of textiles, clothing, \\
\hline
\end{tabular} footwear \& leather goods

\begin{tabular}{l|l} 
Units & Since January 2004 data available as index,
\end{tabular}

June 2001 to December 2003 data available as annual percentage changes,

January 2001 to May 2001 data available as index

$\mathrm{U}$

\begin{tabular}{|l|l|}
\hline Name & Total Turnover Index, deflated, Retail sale of household equipment \\
\hline Units & $\begin{array}{l}\text { Since January 2004 data available as index, } \\
\text { June 2001 to December } 2003 \text { data available as annual percentage } \\
\text { changes, } \\
\text { January 2001 to May 2001 data available as index }\end{array}$ \\
\hline
\end{tabular}

V

\begin{tabular}{|l|l|}
\hline Name & Car registration, New passenger car \\
\hline Units & Absolute value \\
\hline Euro area & Since February 2009: Euro 16 \\
concept & $\begin{array}{l}\text { April 2007 to January 2009: Euro 13 } \\
\text { January 2004 to March 2007: Euro 12 } \\
\end{array}$ \\
& $\begin{array}{l}\text { December 2001 to December 2003: Euro area changing composition } \\
\text { January 2001 to November 2001: Euro 12 }\end{array}$ \\
\hline
\end{tabular}




\begin{tabular}{|c|c|}
\hline Name & Car registration, New passenger car \\
\hline Units & $\begin{array}{l}\text { Since March } 2003 \text { data available as absolute value, } \\
\text { Since December } 2001 \text { to February } 2003 \text { data available as annual } \\
\text { percentage changes, } \\
\text { January } 2001 \text { to November } 2001 \text { data available as absolute value }\end{array}$ \\
\hline $\begin{array}{l}\text { Euro area } \\
\text { concept }\end{array}$ & $\begin{array}{l}\text { Since February 2009: Euro } 16 \\
\text { April } 2007 \text { to January 2009: Euro } 13 \\
\text { January } 2004 \text { to March 2007: Euro } 12 \\
\text { December } 2001 \text { to December 2003: Euro area changing composition } \\
\text { January } 2001 \text { to November 2001: Euro } 12\end{array}$ \\
\hline Adjustment & Working day , non-seasonally adjusted \\
\hline
\end{tabular}

\section{Unemployment and unemployment rate: by gender and by age}

Total

$\mathrm{X} \quad$ Thousands of Persons

Y \% of labour force

By age

\section{Adult}

Z

AA

AB

$\mathrm{AC}$

By gender

Thousands of Persons

$\%$ of labour force

Youth
Thousands of Persons
$\%$ of labour force

Male

AD

Thousands of Persons

AE

$\%$ of labour force

\section{Female}

AF Thousands of Persons

AG \% of labour force

\section{EURO AREA CONCEPT}

Since February 2009: Euro 16

April 2008 to January 2009: Euro 15

March 2007 to March 2008: Euro 13

January 2001 to February 2007: Euro 12

\section{SEASONAL ADJUSTMENT}

All data seasonally adjusted, not working day adjusted

\section{ADDITIONAL NOTES}

- Gradual changes in the unemployment definition in December 2000, March 2002 and June 2002 - see the Monthly Bulletin box "Changes in the definition of unemployment in EU Member States March 2001" for more details. 
- Methodological notes on the ECB's website:

http://www.ecb.int/stats/prices/labour/html/index.en.html

SOURCE: Eurostat

$\mathrm{X}$

\begin{tabular}{|l|c|}
\hline Name & Standardised unemployment, Level, Total (all ages) \\
\hline Units & Thousands of Persons,
\end{tabular}

\begin{tabular}{l|l} 
Units & Thousands of Persons,
\end{tabular}

$\mathrm{Y}$

\begin{tabular}{|l|l|}
\hline Name & Standardised unemployment, Rate, Total (all ages) \\
\hline Units & Percent
\end{tabular}

$\mathrm{Z}$

\begin{tabular}{|l|l|l|l}
\hline Name & Standardised unemployment, Level, 25 and over, Total (male \&
\end{tabular} female)

\begin{tabular}{|l|l|}
\hline Units & Thousands of Persons \\
\hline
\end{tabular}

AA

\begin{tabular}{|l|l|}
\hline Name & $\begin{array}{l}\text { Standardised unemployment, Rate, } 25 \text { and over, Total (male \& } \\
\text { female) }\end{array}$ \\
\hline Units & Percent \\
\hline
\end{tabular}

AB
\begin{tabular}{|l|l|}
\hline Name & $\begin{array}{l}\text { Standardised unemployment, Level, Under 25, Total (male \& } \\
\text { female) }\end{array}$ \\
\hline Units & Thousands of Persons \\
\hline
\end{tabular}

AC
\begin{tabular}{|l|l|}
\hline Name & $\begin{array}{l}\text { Standardised unemployment, Rate, Under 25, Total (male \& } \\
\text { female) }\end{array}$ \\
\hline Units & Percent \\
\hline
\end{tabular}

AD
\begin{tabular}{|l|l|}
\hline Name & Standardised unemployment, Level, Total (all ages), Male \\
\hline Units & Thousands of Persons \\
\hline
\end{tabular}

AE
\begin{tabular}{|l|l|}
\hline Name & Standardised unemployment, Rate, Total (all ages), Male \\
\hline Units & Percent \\
\hline
\end{tabular}

AF
\begin{tabular}{|l|l|}
\hline Name & Standardised unemployment, Level, Total (all ages), Female \\
\hline Units & Thousands of Persons \\
\hline
\end{tabular}

AG
\begin{tabular}{|l|l|}
\hline Name & Standardised unemployment, Rate, Total (all ages), Female \\
\hline Units & Percent \\
\hline
\end{tabular}




\section{Harmonised Index of Consumer Prices}

Total

AH

AI

AJ

AK

AL

AM

AN

AO

AP

AQ

AR

AS

AT

AU

AV
Total (index)

Total (annual rate of change, flash estimate)

All-items excluding energy and unprocessed food

Goods

Goods

Services

Food (incl. alcoholic beverages and tobacco)

Total

Processed food

Industrial goods

Unprocessed food

Non-energy industrial goods

Services

Energy

Housing

Transport

Communication

Recreation and personal

Miscellaneous

\section{EURO AREA CONCEPT}

Since January 2001: Euro area changing composition

SEASONAL ADJUSTMENT

All data neither seasonally nor working day adjusted

\section{ADDITIONAL NOTES}

- Change of the base from 1996 to 2005 in March 2006

- Data from January 2002 onwards- implementation of additional harmonisation rules - treatment of price reductions, coverage of services prices

- Expenditure weights are updated annually, however in January 2003, Germany, The Netherlands and Portugal moved their weight reference period from 1995 to 2000 - this caused revisions notably to the German data.

- Methodological notes on the ECB's website: http://www.ecb.int/stats/prices/hicp/html/index.en.html

SOURCE: Eurostat and ECB calculations

$\mathrm{AH}$ 
AI

\begin{tabular}{|l|l|}
\hline Name & HICP - Overall index, Annual rate of change \\
\hline Comments & Flash estimate \\
\hline
\end{tabular}

$\mathrm{AJ}$

\begin{tabular}{|l|l|l|}
\hline Name & HICP - All-items excluding energy and unprocessed food, Monthly
\end{tabular}

Index,

AK
\begin{tabular}{|l|l|}
\hline Name & HICP - Goods, Monthly Index \\
\hline
\end{tabular}

AL

\begin{tabular}{|l|l|}
\hline Name & HICP - Services, Monthly Index \\
\hline
\end{tabular}

$\mathrm{AM}$

\begin{tabular}{|l|l|}
\hline Name & HICP - Food incl. alcohol and tobacco, Monthly Index \\
\hline
\end{tabular}

AN

\begin{tabular}{|l|l|l|l|l}
\hline Name & HICP - Processed food incl. alcohol and tobacco, Monthly Index
\end{tabular}

$\mathrm{AO}$

\begin{tabular}{|l|l|}
\hline Name & HICP - Unprocessed food, Monthly Index \\
\hline
\end{tabular}

AP

\begin{tabular}{|l|l|}
\hline Name & HICP - Industrial goods excluding energy, Monthly Index \\
\hline
\end{tabular}

AQ

\begin{tabular}{|l|l} 
Name & HICP - Energy, Monthly Index, \\
\hline
\end{tabular}

AR

\begin{tabular}{|l|l|}
\hline Name & HICP - Housing services, Monthly Index
\end{tabular}

AS

\begin{tabular}{|l|l|}
\hline Name & HICP - Transport services, Monthly Index
\end{tabular}

AT

\begin{tabular}{|l|l|}
\hline Name & HICP - Communication, Monthly Index \\
\hline Comments & $\begin{array}{l}\text { Until March 2001 covers only communication services - i.e. excludes } \\
\text { telephone/fax equipment sub-index. After the date also includes } \\
\text { telephone \& telefax equipment sub-index }\end{array}$ \\
\hline
\end{tabular}

AU

\begin{tabular}{|l|l|}
\hline Name & HICP - Recreation and personal services, Monthly Index \\
\hline
\end{tabular}

AV

\begin{tabular}{|l|l|l|}
\hline Name & HICP - Miscellaneous services, Monthly Index
\end{tabular} 


\section{External transactions and position: current and capital account, by}

credit and debt

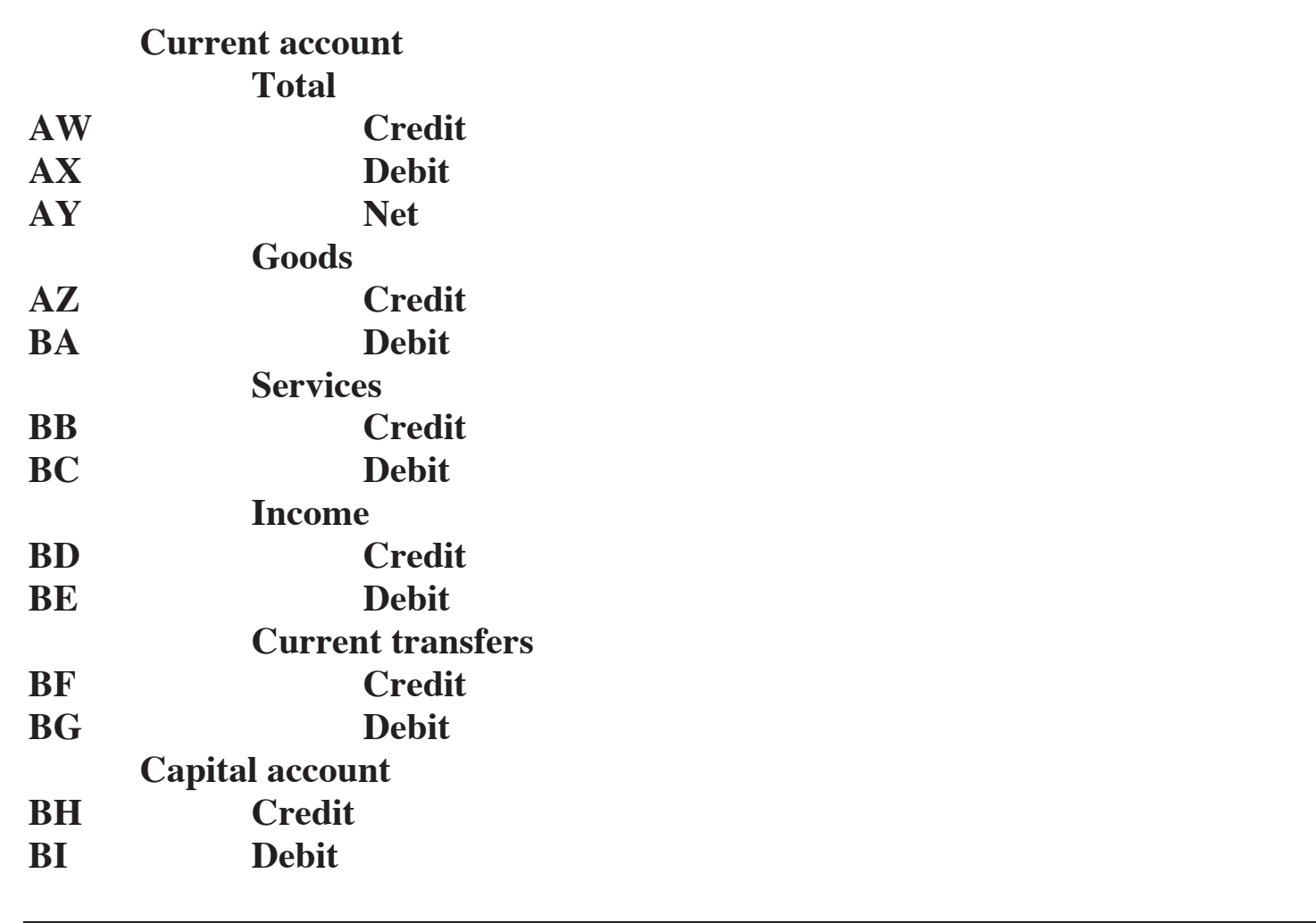

EURO AREA CONCEPT

Since April 2009: Euro 16

April 2008 to March 2009: Euro 15

April 2007 to March 2008: Euro 13

January 2004 to March 2007: Euro 12

January 2001 to December 2003: Euro area changing composition

SEASONAL ADJUSTMENT

Neither seasonally or working day adjusted

ADDITIONAL NOTES

- All data refer to transactions in millions of Euro

- Methodological notes on the ECB's website:

http://www.ecb.int/stats/external/balance/html/index.en.html

SOURCE: ECB

AW

\begin{tabular}{|l|l|}
\hline Name & $\begin{array}{l}\text { Current account - Euro area vis-a-vis World (all entities) - Credit } \\
\text { flows }\end{array}$
\end{tabular}




AX
\begin{tabular}{|l|l|}
\hline Name & $\begin{array}{l}\text { Current account - Euro area vis-a-vis World (all entities) - Debit } \\
\text { flows }\end{array}$ \\
\hline
\end{tabular}

AY
\begin{tabular}{|l|l|}
\hline Name & $\begin{array}{l}\text { Current account - Euro area vis-a-vis World (all entities) - Net } \\
\text { flows }\end{array}$ \\
\hline
\end{tabular}

AZ
\begin{tabular}{|l|l|}
\hline Name & Current account, Goods - Euro area vis-a-vis World (all entities) -
\end{tabular} Credit flows

BA

\begin{tabular}{l|l} 
Name & Current account, Goods - Euro area vis-a-vis World (all entities) - \\
Debit flows -
\end{tabular}

Debit flows - Neither seasonally or working day adjusted

BB

\begin{tabular}{|l|l|}
\hline Name & $\begin{array}{l}\text { Current account, Services - Euro area vis-a-vis World (all entities) } \\
\text { - Credit flows }\end{array}$
\end{tabular}

$\mathrm{BC}$

\begin{tabular}{|l|l|}
\hline Name & Current account, Services - Euro area vis-a-vis World (all entities) \\
\hline
\end{tabular}

- Debit flows

$\mathrm{BD}$

\begin{tabular}{|l|l|}
\hline Name & $\begin{array}{l}\text { Current account, Income - Euro area vis-a-vis World (all entities) - } \\
\text { Credit flows }\end{array}$
\end{tabular}

$\mathrm{BE}$

\begin{tabular}{|l|l|}
\hline Name & Current account, Income - Euro area vis-a-vis World (all entities) - \\
\hline
\end{tabular} Debit flows

$\mathrm{BF}$

\begin{tabular}{|l|l|}
\hline Name & Current account, Current transfers - Euro area vis-a-vis World
\end{tabular} (all entities) - Credit flows

BG

\begin{tabular}{|l|l|}
\hline Name & Current account, Current transfers - Euro area vis-a-vis World (all \\
\hline
\end{tabular} entities) - Debit flows

$\mathrm{BH}$

\begin{tabular}{|l|l|} 
Name & Capital account - Euro area vis-a-vis World (all entities) - Credit
\end{tabular} flows

BG

\begin{tabular}{l|l} 
Name & Capital account - Euro area vis-a-vis World (all entities) - Debit
\end{tabular} flows - 


\section{Exchange rates: effective exchange rates}

Narrow group (EER-12/EER-23)

$\begin{array}{ll}\text { BJ } & \text { Nominal } \\ \text { BK } & \text { Real CPI } \\ \text { BL } & \text { Real PPI } \\ & \text { Broad group (EER-38/EER-42) } \\ \text { BM } & \text { Nominal } \\ \text { BN } & \text { Real CPI }\end{array}$

\section{$\underline{\text { ADDITIONAL NOTES }}$}

- February 2009- new definition for narrow and broad groups

- February 2008- new definition for narrow and broad groups

- February 2007 - new definition for narrow and broad groups

- September 2004 - new definition for narrow and broad groups

- Methodological notes on the ECB's website: http://www.ecb.int/stats/exchange/effective/html/index.en.html

SOURCE: ECB

$\mathrm{BJ}$

\begin{tabular}{|l|l|}
\hline Name & ECB Nominal effective exch. rate, ECB EER core group of
\end{tabular} currencies against Euro

BK

\begin{tabular}{|l|l|}
\hline Name & ECB Real effective exch. rate CPI deflated, ECB EER core group \\
\hline
\end{tabular} of currencies against Euro

BL

\begin{tabular}{|l|l|}
\hline Name & ECB Real effective exch. rate producer prices deflated, ECB EER
\end{tabular} core group of currencies against Euro

$\mathrm{BM}$

\begin{tabular}{|l|l|}
\hline Name & ECB Nominal effective exch. rate, ECB EER broad group of
\end{tabular} currencies against Euro

$\mathrm{BN}$

\begin{tabular}{|l|l|}
\hline Name & ECB Real effective exch. rate CPI deflated, ECB EER broad group
\end{tabular} of currencies against Euro 


\section{Trade in goods: value, volume and unit value by product group}

Value; volume; unit value

\begin{tabular}{|c|c|c|c|c|}
\hline \multirow{2}{*}{ BO; } & \multicolumn{4}{|c|}{ Total } \\
\hline & $\mathrm{CB}$; & $\mathrm{CO}$ & & Exports \\
\hline \multirow[t]{2}{*}{ BP; } & $\mathrm{CC}$ & $\mathbf{C P}$ & & Imports \\
\hline & & & Expor & ts (f.o.b.) \\
\hline BQ; & CD; & CQ & & Total \\
\hline BR; & $\mathrm{CE}$; & CR & & Intermediate \\
\hline BS; & $\mathrm{CF}$ & CS & & Capital \\
\hline BT; & CG; & CT & & Consumption \\
\hline \multirow[t]{2}{*}{ BU; } & $\mathrm{CH}$; & $\mathbf{C U}$ & & Memo: Manufactures \\
\hline & & & Impor & ts (c.i.f.) \\
\hline BV; & CI; & CV & & Total \\
\hline BW; & CJ; & CW & & Intermediate \\
\hline BX; & CK; & CX & & Capital \\
\hline BY; & CL; & CY & & Consumption \\
\hline & & & & Memo: \\
\hline BZ; & CM; & $\mathbf{C Z}$ & & Manufactures \\
\hline $\overrightarrow{\mathrm{CA}}$ & $\mathrm{CN}$; & DA & & Oil \\
\hline
\end{tabular}

\section{EURO AREA CONCEPT}

Since April 2009: Euro 16

April 2008 to March 2009: Euro 15

May 2007 to March 2008: Euro 13

January 2004 to April 2007: Euro 12 (unless otherwise indicated)

January 2001 to December 2003: Euro area changing composition (unless otherwise indicated)

\section{SEASONAL ADJUSTMENT}

Since January 2004: no adjustment (unless otherwise indicated) January 2001 to December 2003: seasonally adjusted, not working day adjusted (unless otherwise indicated)

\section{ADDITIONAL NOTES}

- Change of a base year from 1995 to 2000 in August 2002

- Methodological notes on the ECB's website: http://www.ecb.int/stats/external/trade/html/index.en.html

SOURCE: Eurostat and ECB calculations based on Eurostat data (volume indices and seasonal adjustment of unit value indices)

BO
\begin{tabular}{|l|l|}
\hline Name & $\begin{array}{l}\text { Total trade - Extra Euro area trade, Export Value index } \\
\text { (Community concept) }\end{array}$ \\
\hline Adjustment & $\begin{array}{l}\text { Since January 2004: no adjustment } \\
\text { September 2001 to December 2003: seasonally adjusted, not working }\end{array}$ \\
\hline
\end{tabular}




\begin{tabular}{|l|l|}
\hline & $\begin{array}{l}\text { day adjusted } \\
\text { January } 2001 \text { to August 2001: no adjustment }\end{array}$ \\
\hline Units & $\begin{array}{l}\text { Index }(1995=100) \text { until August } 2002 \text { and }(2000=100) \text { thereafter; } \\
\text { levels in May and June 2007 }\end{array}$ \\
\hline
\end{tabular}

BP

\begin{tabular}{|l|l|}
\hline Name & $\begin{array}{l}\text { Total trade - Extra Euro area trade, Import Value index } \\
\text { (Community concept) }\end{array}$ \\
\hline Adjustment & $\begin{array}{l}\text { Since January 2004: no adjustment } \\
\text { Since September 2001 to December 2003: seasonally adjusted, not } \\
\text { working day adjusted } \\
\text { January 2001 to August 2001: no adjustment }\end{array}$ \\
\hline Units & $\begin{array}{l}\text { Index (1995=100) until August } 2002 \text { and (2000=100) thereafter; } \\
\text { levels in Many and June 2007 }\end{array}$ \\
\hline
\end{tabular}

BQ

\begin{tabular}{|l|l|}
\hline Name & $\begin{array}{l}\text { Total trade - Extra Euro area trade, Export Value (Community } \\
\text { concept) }\end{array}$ \\
\hline Adjustment & $\begin{array}{l}\text { Since January 2004: seasonally adjusted, not working day adjusted } \\
\text { January 2001 to December 2003: no adjustment }\end{array}$ \\
\hline Units & Thousands of ECU/EUR \\
\hline
\end{tabular}

BR

\begin{tabular}{|l|l|}
\hline Name & $\begin{array}{l}\text { Intermediate goods (BEC) - Extra Euro area trade, Export Value } \\
\text { (Community concept) }\end{array}$ \\
\hline Adjustment & $\begin{array}{l}\text { Since January 2004: seasonally adjusted, not working day adjusted } \\
\text { September 2001 to December 2003: no adjustment }\end{array}$ \\
\hline Units & Thousands of ECU/EUR \\
\hline Availability & Since September 2001 \\
\hline
\end{tabular}

BS

\begin{tabular}{|l|l|}
\hline Name & $\begin{array}{l}\text { Capital goods (BEC) - Extra Euro area trade, Export Value } \\
\text { (Community concept), }\end{array}$ \\
\hline Adjustment & $\begin{array}{l}\text { Since January 2004: seasonally adjusted, not working day adjusted } \\
\text { September 2001 to December 2003: no adjustment }\end{array}$ \\
\hline Units & Thousands of ECU/EUR \\
\hline Availability & Since September 2001 \\
\hline
\end{tabular}

BT

\begin{tabular}{|l|l|}
\hline Name & $\begin{array}{l}\text { Consumption goods (consumer goods \& cars \& petrol) (BEC) - } \\
\text { Extra Euro area trade, Export Value (Community concept) }\end{array}$ \\
\hline Adjustment & $\begin{array}{l}\text { Since January 2004: seasonally adjusted, not working day adjusted } \\
\text { September 2001 to December 2003: no adjustment }\end{array}$ \\
\hline Units & Thousands of ECU/EUR \\
\hline Availability & Since September 2001 \\
\hline
\end{tabular}


BU

\begin{tabular}{|l|l|}
\hline Name & $\begin{array}{l}\text { Manufactured products (SITC 5 to 8) - Extra Euro area trade, } \\
\text { Export Value (Community concept) }\end{array}$ \\
\hline Adjustment & $\begin{array}{l}\text { Since January 2004: seasonally adjusted, not working day adjusted } \\
\text { September 2001 to December 2003: no adjustment }\end{array}$ \\
\hline Units & Thousands of ECU/EUR \\
\hline Availability & Since September 2001 \\
\hline
\end{tabular}

\begin{tabular}{|l|l|}
\multicolumn{2}{|l}{ BV } \\
\begin{tabular}{|l|l|}
\hline Name & Total trade - Extra Euro area trade, Import Value (Community \\
concept)
\end{tabular} \\
\hline Adjustment & $\begin{array}{l}\text { Since January 2004: seasonally adjusted, not working day adjusted } \\
\text { January 2001 to December 2003: no adjustment }\end{array}$ \\
\hline Units & Thousands of ECU/EUR \\
\hline
\end{tabular}

BW

\begin{tabular}{|l|l|}
\hline Name & $\begin{array}{l}\text { Intermediate goods (BEC) - Extra Euro area trade, Import Value } \\
\text { (Community concept) }\end{array}$ \\
\hline Adjustment & $\begin{array}{l}\text { Since January 2004: seasonally adjusted, not working day adjusted } \\
\text { September 2001 to December 2003: no adjustment }\end{array}$ \\
\hline Units & Thousands of ECU/EUR \\
\hline Availability & Since September 2001 \\
\hline
\end{tabular}

BX
\begin{tabular}{|l|l|}
\hline Name & $\begin{array}{l}\text { Capital goods (BEC) - Extra Euro area trade, Import Value } \\
\text { (Community concept) }\end{array}$ \\
\hline Adjustment & $\begin{array}{l}\text { Since January 2004: seasonally adjusted, not working day adjusted } \\
\text { September 2001 to December 2003: no adjustment }\end{array}$ \\
\hline Units & Thousands of ECU/EUR \\
\hline Availability & Since September 2001 \\
\hline
\end{tabular}

BY

\begin{tabular}{|l|l|}
\hline Name & $\begin{array}{l}\text { Consumption goods (consumer goods \& cars \& petrol) (BEC) - } \\
\text { Extra Euro area trade, Import Value (Community concept), }\end{array}$ \\
\hline Adjustment & $\begin{array}{l}\text { Since January 2004: seasonally adjusted, not working day adjusted } \\
\text { September 2001 to December 2003: no adjustment }\end{array}$ \\
\hline Units & Thousands of ECU/EUR \\
\hline Availability & Since September 2001 \\
\hline
\end{tabular}

BZ

\begin{tabular}{|l|l|}
\hline Name & $\begin{array}{l}\text { Manufactured products (SITC 5 to 8) - Extra Euro area trade, } \\
\text { Import Value (Community concept), }\end{array}$ \\
\hline Adjustment & $\begin{array}{l}\text { Since January 2004: seasonally adjusted, not working day adjusted } \\
\text { September 2001 to December 2003: no adjustment }\end{array}$ \\
\hline Units & Thousands of ECU/EUR \\
\hline Availability & Since September 2001 \\
\hline
\end{tabular}


CA

\begin{tabular}{|l|l|}
\hline Name & $\begin{array}{l}\text { Petroleum, petroleum products and related materials (SITC 33) - } \\
\text { Extra Euro area trade, Import Value (Community concept) }\end{array}$ \\
\hline Adjustment & $\begin{array}{l}\text { Since January 2004: seasonally adjusted, not working day adjusted } \\
\text { September 2001 to December 2003: no adjustment }\end{array}$ \\
\hline Units & Thousands of ECU/EUR \\
\hline Availability & Since September 2001 \\
\hline
\end{tabular}

CB

\begin{tabular}{|l|l|}
\hline Name & $\begin{array}{l}\text { Total trade - Extra Euro area trade, Export Volume index } \\
\text { (Community concept), }\end{array}$ \\
\hline Adjustment & $\begin{array}{l}\text { Since January 2004: no adjustment } \\
\text { September 2001 to December 2003: seasonally adjusted, not working } \\
\text { day adjusted } \\
\text { January 2001 to August 2001: no adjustment }\end{array}$ \\
\hline Units & Index (1995=100) until August 2002 and (2000=100) thereafter \\
\hline
\end{tabular}

CC

\begin{tabular}{|l|l|}
\hline Name & $\begin{array}{l}\text { Total trade - Extra Euro area trade, Import Volume index } \\
\text { (Community concept) }\end{array}$ \\
\hline Adjustment & $\begin{array}{l}\text { Since January 2004: no adjustment } \\
\text { September 2001 to December 2003: seasonally adjusted, not working } \\
\text { day adjusted } \\
\text { January 2001 to August 2001: no adjustment }\end{array}$ \\
\hline
\end{tabular}

CD

\begin{tabular}{|l|l|}
\hline Name & $\begin{array}{l}\text { Total trade - Extra Euro area trade, Year-to-year percentage } \\
\text { change of Volume index (Community concept) }\end{array}$ \\
\hline Adjustment & $\begin{array}{l}\text { Since January 2004: seasonally adjusted, not working day adjusted } \\
\text { September 2001 to December 2003: no adjustment }\end{array}$ \\
\hline Units & $\begin{array}{l}\text { Since January 2004 data available as index, } \\
\text { September 2001 to December 2003 data available as annual percentage } \\
\text { changes }\end{array}$ \\
\hline Availability & Since September 2001 \\
\hline
\end{tabular}

CE

\begin{tabular}{|l|l|}
\hline Name & $\begin{array}{l}\text { Intermediate goods (BEC) - Extra Euro area trade, Year-to-year } \\
\text { percentage change of Volume index (Community concept), Export, }\end{array}$ \\
\hline Adjustment & $\begin{array}{l}\text { Since January 2004: seasonally adjusted, not working day adjusted } \\
\text { September 2001 to December 2003: no adjustment }\end{array}$ \\
\hline Units & $\begin{array}{l}\text { Since January 2004 data available as index, } \\
\text { September 2001 to December 2003 data available as annual percentage } \\
\text { changes }\end{array}$ \\
\hline Availability & Since September 2001 \\
\hline
\end{tabular}


CF

\begin{tabular}{|l|l|}
\hline Name & $\begin{array}{l}\text { Capital goods (BEC) - Extra Euro area trade, Year-to-year } \\
\text { percentage change of Volume index (Community concept), Export }\end{array}$ \\
\hline Adjustment & $\begin{array}{l}\text { Since January 2004: seasonally adjusted, not working day adjusted } \\
\text { September 2001 to December 2003: no adjustment }\end{array}$ \\
\hline Units & $\begin{array}{l}\text { Since January 2004 data available as index, } \\
\text { September 2001 to December 2003 data available as annual percentage } \\
\text { changes }\end{array}$ \\
\hline Availability & Since September 2001 \\
\hline
\end{tabular}

CG

\begin{tabular}{|l|l|}
\hline Name & $\begin{array}{l}\text { Consumption goods (consumer goods \& cars \& petrol) (BEC) - } \\
\text { Extra Euro area trade, Year-to-year percentage change of Volume } \\
\text { index (Community concept), Export }\end{array}$ \\
\hline Adjustment & $\begin{array}{l}\text { Since January 2004: seasonally adjusted, not working day adjusted } \\
\text { September 2001 to December 2003: no adjustment }\end{array}$ \\
\hline Units & $\begin{array}{l}\text { Since January 2004 data available as index, } \\
\text { September 2001 to December 2003 data available as annual percentage } \\
\text { changes }\end{array}$ \\
\hline Availability & Since September 2001 \\
\hline
\end{tabular}

$\mathrm{CH}$

\begin{tabular}{|l|l|}
\hline Name & $\begin{array}{l}\text { Manufactured products (SITC 5 to 8) - Extra Euro area trade, } \\
\text { Year-to-year percentage change of Volume index (Community } \\
\text { concept), Export }\end{array}$ \\
\hline Adjustment & $\begin{array}{l}\text { Since January 2004: seasonally adjusted, not working day adjusted } \\
\text { September 2001 to December 2003: no adjustment }\end{array}$ \\
\hline Units & $\begin{array}{l}\text { Since January 2004 data available as index, } \\
\text { September 2001 to December 2003 data available as annual percentage } \\
\text { changes }\end{array}$ \\
\hline Availability & Since September 2001 \\
\hline
\end{tabular}

CI

\begin{tabular}{|l|l|}
\hline Name & $\begin{array}{l}\text { Total trade - Extra Euro area trade, Year-to-year percentage } \\
\text { change of Volume index (Community concept), Import }\end{array}$ \\
\hline Adjustment & $\begin{array}{l}\text { Since January 2004: seasonally adjusted, not working day adjusted } \\
\text { September 2001 to December 2003: no adjustment }\end{array}$ \\
\hline Units & $\begin{array}{l}\text { Since January 2004 data available as index, } \\
\text { September 2001 to December 2003 data available as annual percentage } \\
\text { changes }\end{array}$ \\
\hline Availability & Since September 2001 \\
\hline
\end{tabular}

CJ

\begin{tabular}{|l|l|}
\hline Name & $\begin{array}{l}\text { Intermediate goods (BEC) - Extra Euro area trade, Year-to-year } \\
\text { percentage change of Volume index (Community concept), Import }\end{array}$ \\
\hline Adjustment & $\begin{array}{l}\text { Since January 2004: seasonally adjusted, not working day adjusted } \\
\text { September 2001 to December 2003: no adjustment }\end{array}$ \\
\hline Units & Since January 2004 data available as index, \\
\hline
\end{tabular}




\begin{tabular}{|l|l|}
\hline & $\begin{array}{l}\text { September } 2001 \text { to December } 2003 \text { data available as annual percentage } \\
\text { changes }\end{array}$ \\
\hline Availability & Since September 2001 \\
\hline
\end{tabular}

CK
\begin{tabular}{|l|l|}
\hline Name & $\begin{array}{l}\text { Capital goods (BEC) - Extra Euro area trade, Year-to-year } \\
\text { percentage change of Volume index (Community concept), Import }\end{array}$ \\
\hline Adjustment & $\begin{array}{l}\text { Since January 2004: seasonally adjusted, not working day adjusted } \\
\text { September 2001 to December 2003: no adjustment }\end{array}$ \\
\hline Units & $\begin{array}{l}\text { Since January 2004 data available as index, } \\
\text { September 2001 to December 2003 data available as annual percentage } \\
\text { changes }\end{array}$ \\
\hline Availability & Since September 2001 \\
\hline
\end{tabular}

CL

\begin{tabular}{|l|l|}
\hline Name & $\begin{array}{l}\text { Consumption goods (consumer goods \& cars \& petrol) (BEC) - } \\
\text { Extra Euro area trade, Year-to-year percentage change of Volume } \\
\text { index (Community concept), Import }\end{array}$ \\
\hline Adjustment & $\begin{array}{l}\text { Since January 2004: seasonally adjusted, not working day adjusted } \\
\text { September 2001 to December 2003: no adjustment }\end{array}$ \\
\hline Units & $\begin{array}{l}\text { Since January 2004 data available as index, } \\
\text { September 2001 to December 2003 data available as annual percentage } \\
\text { changes }\end{array}$ \\
\hline Availability & Since September 2001 \\
\hline
\end{tabular}

CM

\begin{tabular}{|l|l|}
\hline Name & $\begin{array}{l}\text { Manufactured products (SITC 5 to 8) - Extra Euro area trade, } \\
\text { Year-to-year percentage change of Volume index (Community } \\
\text { concept), Import }\end{array}$ \\
\hline Adjustment & $\begin{array}{l}\text { Since January 2004: seasonally adjusted, not working day adjusted } \\
\text { September 2001 to December 2003: no adjustment }\end{array}$ \\
\hline Units & $\begin{array}{l}\text { Since January 2004 data available as index, } \\
\text { September 2001 to December 2003 data available as annual percentage } \\
\text { changes }\end{array}$ \\
\hline Availability & Since September 2001 \\
\hline
\end{tabular}

CN
\begin{tabular}{|l|l|}
\hline Name & $\begin{array}{l}\text { Petroleum, petroleum products and related materials (SITC 33) - } \\
\text { Extra Euro area trade, Year-to-year percentage change of Volume } \\
\text { index (Community concept), Import }\end{array}$ \\
\hline Adjustment & $\begin{array}{l}\text { Since January 2004: seasonally adjusted, not working day adjusted } \\
\text { September 2001 to December 2003: no adjustment }\end{array}$ \\
\hline Units & $\begin{array}{l}\text { Since January 2004 data available as index, } \\
\text { September 2001 to December 2003 data available as annual percentage } \\
\text { changes }\end{array}$ \\
\hline Availability & Since September 2001 \\
\hline
\end{tabular}




\begin{tabular}{|l|l|} 
CO & Name \\
\hline Adjustment & $\begin{array}{l}\text { Total trade - Extra Euro 12 trade, Export Unit value index } \\
\text { (Community concept) }\end{array}$ \\
$\begin{array}{l}\text { Since January 2004: no adjustment } \\
\text { September 2001 to December 2003: seasonally adjusted, not working } \\
\text { day adjusted } \\
\text { January 2001 to August 2001: no adjustment }\end{array}$ \\
\hline
\end{tabular}

CP
\begin{tabular}{|l|l|}
\hline Name & $\begin{array}{l}\text { Total trade - Extra Euro area trade, Import Unit value index } \\
\text { (Community concept) }\end{array}$ \\
\hline Adjustment & $\begin{array}{l}\text { Since January 2004: no adjustment } \\
\text { September 2001 to December 2003: seasonally adjusted, not working } \\
\text { day adjusted } \\
\text { January 2001 to August 2001: no adjustment }\end{array}$ \\
\hline
\end{tabular}

CQ
\begin{tabular}{|l|l|}
\hline Name & $\begin{array}{l}\text { Total trade - Extra Euro 12 trade, Export Unit value index } \\
\text { (Community concept) }\end{array}$ \\
\hline $\begin{array}{l}\text { Euro area } \\
\text { concept }\end{array}$ & $\begin{array}{l}\text { Since April 2009: Euro 16 } \\
\text { April 2008 to March 2009: Euro 15 } \\
\text { May 2007 to March 2008: Euro 13 } \\
\text { August 2002 to April 2007: Euro 12 } \\
\text { September 2001 to July 2002: Euro 11 }\end{array}$ \\
\hline Adjustment & $\begin{array}{l}\text { Since April 2008: no adjustment } \\
\text { May 2005 to March 2008: seasonally and working day adjusted } \\
\text { January 2004 to April 2007: seasonally adjusted, not working day } \\
\text { adjusted } \\
\text { September 2001 to December 2003: no adjustment }\end{array}$ \\
\hline Availability & Since September 2001, no data between September and December 2002 \\
\hline
\end{tabular}

\begin{tabular}{|c|c|}
\hline Name & $\begin{array}{l}\text { Intermediate goods (BEC) - Extra Euro } 12 \text { trade, Export Unit } \\
\text { value index (Community concept) }\end{array}$ \\
\hline $\begin{array}{l}\text { Euro area } \\
\text { concept }\end{array}$ & $\begin{array}{l}\text { Since April 2009: Euro 16 } \\
\text { April } 2008 \text { to March 2009: Euro } 15 \\
\text { May } 2007 \text { to March 2008: Euro } 13 \\
\text { August } 2002 \text { to April 2007: Euro } 12 \\
\text { September } 2001 \text { to July 2002: Euro } 11\end{array}$ \\
\hline Adjustment & $\begin{array}{l}\text { Since April 2008: no adjustment } \\
\text { May } 2005 \text { to March 2008: seasonally and working day adjusted } \\
\text { January } 2004 \text { to April 2007: seasonally adjusted, not working day } \\
\text { adjusted } \\
\text { September } 2001 \text { to December 2003: no adjustment }\end{array}$ \\
\hline Availability & Since September 2001, no data between September and December 2002 \\
\hline
\end{tabular}




\begin{tabular}{|l|l|} 
CS \\
\begin{tabular}{|l|l|}
\hline Name & $\begin{array}{l}\text { Capital goods (BEC) - Extra Euro 12 trade, Export Unit value } \\
\text { index (Community concept) }\end{array}$ \\
\hline Euro area & Since April 2009: Euro 16 \\
April 2008 to March 2009: Euro 15 \\
May 2007 to March 2008: Euro 13 \\
August 2002 to April 2007: Euro 12 \\
September 2001 to July 2002: Euro 11
\end{tabular} \\
\hline Adjustment & $\begin{array}{l}\text { Since April 2008: no adjustment } \\
\text { May 2005 to March 2008: seasonally and working day adjusted } \\
\text { January 2004 to April 2007: seasonally adjusted, not working day } \\
\text { adjusted } \\
\text { September 2001 to December 2003: no adjustment }\end{array}$ \\
\hline Availability & Since September 2001, no data between September and December 2002 \\
\hline
\end{tabular}

CT

\begin{tabular}{|l|l|}
\hline Name & $\begin{array}{l}\text { Consumption goods (consumer goods \& cars \& petrol) (BEC) - } \\
\text { Extra Euro 12 trade, Export Unit value index (Community } \\
\text { concept) }\end{array}$ \\
\hline $\begin{array}{l}\text { Euro area } \\
\text { concept }\end{array}$ & $\begin{array}{l}\text { Since April 2009: Euro 16 } \\
\text { April 2008 to March 2009: Euro 15 } \\
\text { May 2007 to March 2008: Euro 13 } \\
\text { August 2002 to April 2007: Euro 12 } \\
\text { September 2001 to July 2002: Euro 11 }\end{array}$ \\
\hline Adjustment & $\begin{array}{l}\text { Since April 2008: no adjustment } \\
\text { May 2005 to March 2008: seasonally and working day adjusted } \\
\text { January 2004 to April 2007: seasonally adjusted, not working day } \\
\text { adjusted } \\
\text { September 2001 to December 2003: no adjustment }\end{array}$ \\
\hline Availability & Since September 2001, no data between September and December 2002 \\
\hline
\end{tabular}

CU

\begin{tabular}{|c|c|}
\hline Name & $\begin{array}{l}\text { Manufactured products (SITC } 5 \text { to 8) - Extra Euro } 12 \text { trade, } \\
\text { Export Unit value index (Community concept) }\end{array}$ \\
\hline $\begin{array}{l}\text { Euro area } \\
\text { concept }\end{array}$ & $\begin{array}{l}\text { Since April 2009: Euro 16 } \\
\text { April } 2008 \text { to March 2009: Euro } 15 \\
\text { May } 2007 \text { to March 2008: Euro } 13 \\
\text { August } 2002 \text { to April 2007: Euro } 12 \\
\text { September } 2001 \text { to July 2002: Euro } 11\end{array}$ \\
\hline Adjustment & $\begin{array}{l}\text { Since April 2008: no adjustment } \\
\text { May } 2005 \text { to March 2008: seasonally and working day adjusted } \\
\text { January } 2004 \text { to April 2007: seasonally adjusted, not working day } \\
\text { adjusted } \\
\text { September } 2001 \text { to December 2003: no adjustment }\end{array}$ \\
\hline Availability & Since September 2001, no data between September and December 2002 \\
\hline
\end{tabular}




\begin{tabular}{|l|l|} 
CV & \multicolumn{1}{|l|}{ Name } \\
\hline $\begin{array}{l}\text { Euro area } \\
\text { concept } \\
\text { (Community concept) }\end{array}$ & $\begin{array}{l}\text { Since April 2009: Euro 16 } \\
\text { April 2008 to March 2009: Euro 15 } \\
\text { May 2007 to March 2008: Euro 13 } \\
\text { August 2002 to April 2007: Euro 12 } \\
\text { September 2001 to July 2002: Euro 11 }\end{array}$ \\
\hline Adjustment & $\begin{array}{l}\text { Since April 2008: no adjustment } \\
\text { May 2005 to March 2008: seasonally and working day adjusted } \\
\text { January 2004 to April 2007: seasonally adjusted, not working day } \\
\text { adjusted } \\
\text { September 2001 to December 2003: no adjustment }\end{array}$ \\
\hline Availability & Since September 2001 no data between September and December 2002 \\
\hline
\end{tabular}

\begin{tabular}{|c|c|}
\hline Name & $\begin{array}{l}\text { Intermediate goods (BEC) - Extra Euro } 12 \text { trade, Import Unit } \\
\text { value index (Community concept) }\end{array}$ \\
\hline $\begin{array}{l}\text { Euro area } \\
\text { concept }\end{array}$ & $\begin{array}{l}\text { Since April 2009: Euro 16 } \\
\text { April } 2008 \text { to March 2009: Euro } 15 \\
\text { May } 2007 \text { to March 2008: Euro } 13 \\
\text { August } 2002 \text { to April 2007: Euro } 12 \\
\text { September } 2001 \text { to July 2002: Euro } 11\end{array}$ \\
\hline Adjustment & $\begin{array}{l}\text { Since April 2008: no adjustment } \\
\text { May } 2005 \text { to March 2008: seasonally and working day adjusted } \\
\text { January } 2004 \text { to April 2007: seasonally adjusted, not working day } \\
\text { adjusted } \\
\text { September } 2001 \text { to December 2003: no adjustment }\end{array}$ \\
\hline Availability & Since September 2001, no data between September and December 2002 \\
\hline
\end{tabular}

CX
\begin{tabular}{|l|l|}
\hline Name & $\begin{array}{l}\text { Capital goods (BEC) - Extra Euro 12 trade, Import Unit value } \\
\text { index (Community concept) }\end{array}$ \\
\hline $\begin{array}{l}\text { Euro area } \\
\text { concept }\end{array}$ & $\begin{array}{l}\text { Since April 2009: Euro 16 } \\
\text { April 2008 to March 2009: Euro 15 } \\
\text { May 2007 to March 2008: Euro 13 } \\
\text { August 2002 to April 2007: Euro 12 } \\
\text { September 2001 to July 2002: Euro 11 }\end{array}$ \\
\hline Adjustment & $\begin{array}{l}\text { Since April 2008: no adjustment } \\
\text { May 2005 to March 2008: seasonally and working day adjusted } \\
\text { January 2004 to April 2007: seasonally adjusted, not working day } \\
\text { adjusted } \\
\text { September 2001 to December 2003: no adjustment }\end{array}$ \\
\hline Availability & Since September 2001, no data between September and December 2002 \\
\hline
\end{tabular}




\begin{tabular}{|l|l|}
\multicolumn{2}{l|}{ CY } \\
\begin{tabular}{|l|l|}
\hline Name & $\begin{array}{l}\text { Consumption goods (consumer goods \& cars \& petrol) (BEC) - } \\
\text { Extra Euro 12 trade, Import Unit value index (Community } \\
\text { concept) }\end{array}$ \\
\hline $\begin{array}{l}\text { Euro area } \\
\text { concept }\end{array}$ & $\begin{array}{l}\text { Since April 2009: Euro 16 } \\
\text { April 2008 to March 2009: Euro 15 } \\
\text { May 2007 to March 2008: Euro 13 } \\
\text { August 2002 to April 2007: Euro 12 } \\
\text { September 2001 to July 2002: Euro 11 }\end{array}$ \\
\hline Adjustment & $\begin{array}{l}\text { Since April 2008: no adjustment } \\
\text { May 2005 to March 2008: seasonally and working day adjusted } \\
\text { January 2004 to April 2007: seasonally adjusted, not working day } \\
\text { adjusted } \\
\text { September 2001 to December 2003: no adjustment }\end{array}$ \\
\hline Availability & Since September 2001, no data between September and December 2002 \\
\hline
\end{tabular} \\
\hline
\end{tabular}

\section{CZ}

\begin{tabular}{|l|l|}
\hline Name & $\begin{array}{l}\text { Manufactured products (SITC 5 to 8) - Extra Euro 12 trade, } \\
\text { Import Unit value index (Community concept) }\end{array}$ \\
\hline $\begin{array}{l}\text { Euro area } \\
\text { concept }\end{array}$ & $\begin{array}{l}\text { Since April 2009: Euro 16 } \\
\text { April 2008 to March 2009: Euro 15 } \\
\text { May 2007 to March 2008: Euro 13 } \\
\text { August 2002 to April 2007: Euro 12 } \\
\text { September 2001 to July 2002: Euro 11 }\end{array}$ \\
\hline Adjustment & $\begin{array}{l}\text { Since April 2008: no adjustment } \\
\text { May 2005 to March 2008: seasonally and working day adjusted } \\
\text { January 2004 to April 2007: seasonally adjusted, not working day } \\
\text { adjusted } \\
\text { September 2001 to December 2003: no adjustment }\end{array}$ \\
\hline Availability & Since September 2001, no data between September and December 2002 \\
\hline
\end{tabular}

DA

\begin{tabular}{|l|l|}
\hline Name & $\begin{array}{l}\text { Petroleum, petroleum products and related materials (SITC 33) - } \\
\text { Extra Euro 12 trade, Import Unit value index (Community } \\
\text { concept) }\end{array}$ \\
\hline $\begin{array}{l}\text { Euro area } \\
\text { concept }\end{array}$ & $\begin{array}{l}\text { Since April 2009: Euro 16 } \\
\text { April 2008 to March 2009: Euro 15 } \\
\text { May 2007 to March 2008: Euro 13 } \\
\text { August 2002 to April 2007: Euro 12 } \\
\text { September 2001 to February 2003: Euro 11 }\end{array}$ \\
\hline Adjustment & $\begin{array}{l}\text { Since April 2008: no adjustment } \\
\text { May 2005 to March 2008: seasonally and working day adjusted } \\
\text { January 2004 to April 2007: seasonally adjusted, not working day } \\
\text { adjusted. } \\
\text { September 2001 to December 2003: no adjustment }\end{array}$ \\
\hline Availability & Since September 2001 \\
\hline
\end{tabular}




\section{Interest rate, money market overnight, 1 to 12 months, US and Japan}

$\underline{3 \text { months }}$

$\begin{array}{lc} & \text { Euro area } \\ \text { DB } & \text { Overnight deposits (EONIA) } \\ \text { DC } & \text { 1-month deposits (EURIBOR) } \\ \text { DD } & \text { 3-month deposits (EURIBOR) } \\ \text { DE } & \text { 6-month deposits (EURIBOR) } \\ \text { DF } & \text { 12-month deposits (EURIBOR) } \\ & \text { United States } \\ \text { DG } & \text { 3-month deposits (LIBOR) } \\ & \text { Japan } \\ \text { DH } & \text { 3-month deposits (LIBOR) }\end{array}$

ADDITIONAL NOTES

- All data expressed as percent per annum

- Methodological notes on the ECB's website: http://www.ecb.int/stats/money/indices/html/index.en.html

SOURCE: ECB

\section{DB}

\begin{tabular}{|l|l|}
\hline Name & $\begin{array}{l}\text { Euro area - Money Market - Eonia rate- Last trade price or value } \\
\text { - Euro }\end{array}$ \\
\hline
\end{tabular}

DC

\begin{tabular}{|l|l|}
\hline Name & Euro area - Money Market - 1-month Euribor- Last trade price or \\
\hline
\end{tabular} value - Euro

DD

\begin{tabular}{|l|l|}
\hline Name & $\begin{array}{l}\text { Euro area - Money Market - 3-month Euribor - Last trade price or } \\
\text { value - Euro }\end{array}$ \\
\hline
\end{tabular}

\section{DE}

\begin{tabular}{|l|l|}
\hline Name & Euro area - Money Market - 6-month Euribor- Last trade price or \\
\hline
\end{tabular} value - Euro

\section{DF}

\begin{tabular}{|l|l|}
\hline Name & Euro area - Money Market - 1-year Euribor- Last trade price or \\
\hline
\end{tabular} value - Euro

DG

\begin{tabular}{|l|l|}
\hline Name & United States - Money Market - 3-month Libor interbank USD
\end{tabular} deposit rate - Last trade price or value - US dollar 
$\mathrm{DH}$

\begin{tabular}{|l|l|}
\hline Name & Japan - Money Market - 3-month Libor interbank Japanese Yen
\end{tabular} deposit rate - Last trade price or value - Japanese yen

\section{Government bond yield 2, 3,5 710 years, US and Japan, 10 years}

\begin{tabular}{|c|c|}
\hline \multicolumn{2}{|r|}{ Euro area } \\
\hline DI & 2 years \\
\hline DJ & 3 years \\
\hline DK & 5 years \\
\hline DL & 7 years \\
\hline DM & 10 years \\
\hline & United States \\
\hline DN & 10 years \\
\hline & Japan \\
\hline DO & 10 years \\
\hline
\end{tabular}

ADDITIONAL NOTES

- All data expressed as percent per annum

- Methodological notes on the ECB's website:

http://www.ecb.int/stats/money/indices/html/index.en.html

SOURCE: ECB

\section{DI}

\begin{tabular}{|l|l|}
\hline Name & 2-year Euro area Government Benchmark bond yield - Euro
\end{tabular}

DJ

\begin{tabular}{|l|l|}
\hline Name & 3-year Euro area Government Benchmark bond yield- Euro \\
\hline
\end{tabular}

DK

\begin{tabular}{|l|l|}
\hline Name & 5-year Euro area Government Benchmark bond yield- Euro \\
\hline
\end{tabular}

DL

\begin{tabular}{|l|l|}
\hline Name & 7-year Euro area Government Benchmark bond yield- Euro \\
\hline
\end{tabular}

DM

\begin{tabular}{|l|l}
\hline Name & 10-year Euro area Government Benchmark bond yield- Euro
\end{tabular}

DN

\begin{tabular}{|l|l|}
\hline Name & USA 10-year Government Benchmark bond yield - US dollar \\
\hline
\end{tabular}

DO

\begin{tabular}{|l|l|}
\hline Name & Japan 10-year Government Benchmark bond yield- Japanese yen, \\
\hline
\end{tabular} 


\section{Dow Jones EURO STOXX indices by economics sectors, S\&P and $\underline{\text { Nikkei }}$}

DP

DQ

DR

DS

DT

DU

DV

DW

DX

DY

DZ

EA

EB

EC
Dow Jones EURO STOXX indices

Benchmark

Broad

50

Main economic sector indices

Basic materials

Consumer cyclical

Consumer non-cyclical

Energy

Financial

Industrial

Technology

Utilities

Telecom

United States

Healthcare

Standard \& Poor's 500

Japan

Nikkei 225

ADDITIONAL NOTES

- All data expressed as index levels in points; period averages

- In November 2004 the formerly published "Consumer cyclical" and "Consumer non-cyclical" indices have been discontinued by STOXX Ltd and replaced by "Consumer services" and "Consumer goods" respectively. The former "Economic sectors" have now been replaced by "Industries" and the composition of the indices is different.

- Methodological notes on the ECB's website:

http://www.ecb.int/stats/money/indices/html/index.en.html

SOURCE: ECB

DP

\begin{tabular}{|l|l|}
\hline Name & Euro area - Equity/index - Dow Jones Euro Stoxx Broad stock \\
\cline { 1 - 1 }
\end{tabular} exchange index - Historical close - Euro

DQ

\begin{tabular}{|l|l}
\hline Name & Euro area - Equity/index - Dow Jones Eurostoxx 50 index -
\end{tabular}

Historical close - Euro

DR

\begin{tabular}{|l|l|}
\hline Name & Euro area - Equity/index - Dow Jones, Euro Stoxx, Economic \\
\hline
\end{tabular} sector index Basic Materials - Historical close - Euro 
DS

\begin{tabular}{|l|l|}
\hline Name & Euro area - Equity/index - Dow Jones, Euro Stoxx, Economic \\
\hline
\end{tabular} sector index Cyclical Goods - Historical close - Euro

DT

\begin{tabular}{|l|l} 
Name & Euro area - Equity/index - Dow Jones, Euro Stoxx, Economic
\end{tabular} sector index Non Cyclical Goods - Historical close - Euro

DU

\begin{tabular}{|l|l|}
\hline Name & Euro area - Equity/index - Dow Jones, Euro Stoxx, Economic \\
\hline
\end{tabular} sector index Energy - Historical close - Euro

DV

\begin{tabular}{|l|l}
\hline Name & Euro area - Equity/index - Dow Jones, Euro Stoxx, Economic
\end{tabular} sector index Financial - Historical close - Euro

DW

\begin{tabular}{|l|l|}
\hline Name & Euro area - Equity/index - Dow Jones, Euro Stoxx, Economic
\end{tabular} sector index Financial - Historical close - Euro

DX

\begin{tabular}{|l|l}
\hline Name & Euro area - Equity/index - Dow Jones, Euro Stoxx, Economic
\end{tabular} sector index Technology - Historical close - Euro

DY

\begin{tabular}{|l|l|}
\hline Name & $\begin{array}{l}\text { Euro area - Equity/index - Dow Jones, Euro Stoxx, Economic } \\
\text { sector index Utilities - Historical close - Euro }\end{array}$ \\
\hline Comments & $\begin{array}{l}\text { In the vintages of February and March 2001 some observations are } \\
\text { missing (not published in the Monthly Bulletin at that time) }\end{array}$ \\
\hline
\end{tabular}

DZ

\begin{tabular}{|l|l|}
\hline Name & $\begin{array}{l}\text { Euro area - Equity/index - Dow Jones, Euro Stoxx, Economic } \\
\text { sector index Telecommunications - Historical close - Euro }\end{array}$ \\
\hline Comments & $\begin{array}{l}\text { In the vintages of February and March 2001 some observations are } \\
\text { missing (not published in the Monthly Bulletin at that time) }\end{array}$ \\
\hline
\end{tabular}

EA

\begin{tabular}{|l|l|}
\hline Name & $\begin{array}{l}\text { Euro area - Equity/index - Dow Jones, Euro Stoxx, Economic } \\
\text { sector index Healthcare - Historical close - Euro }\end{array}$ \\
\hline Comments & $\begin{array}{l}\text { In the vintages of February and March 2001 some observations are } \\
\text { missing (not published in the Monthly Bulletin at that time) }\end{array}$ \\
\hline
\end{tabular}

EB

\begin{tabular}{|l|l|}
\hline Name & $\begin{array}{l}\text { United States - Equity/index - Standard \& Poor } 500 \text { Equity Index - } \\
\text { Historical close - US dollar }\end{array}$
\end{tabular}

EC

\begin{tabular}{|l|l}
\hline Name & Japan - Equity/index - Nikkei 225 equity index - Last trade price
\end{tabular} or value - Japanese yen 


\section{US and Japan: main economic and financial indicators}

\section{United States}

\begin{tabular}{|c|c|}
\hline ED & Consumer price index \\
\hline $\mathbf{E E}$ & Industrial production index (manufacturing) \\
\hline $\mathbf{E F}$ & Unemployment rate \\
\hline EG & Broad money \\
\hline \multicolumn{2}{|c|}{ Japan } \\
\hline EH & Consumer price index \\
\hline EI & Unit labour costs (manufacturing) \\
\hline EJ & Industrial production index (manufacturing) \\
\hline EK & Unemployment rate \\
\hline EL & Broad money \\
\hline
\end{tabular}

SOURCE: BIS

ED

\begin{tabular}{|l|l|}
\hline Name & US-Consumer price index \\
\hline Units & Since January 2001 Index, 1982/1984=100 \\
\hline
\end{tabular}

EE

\begin{tabular}{|l|l|}
\hline Name & US-Industrial production index (manufacturing) \\
\hline Units & $\begin{array}{l}\text { Since January } 2003 \text { Index, 1997=100 } \\
\text { January 2001 to December 2002 Index, 1989 = 100, }\end{array}$ \\
\hline
\end{tabular}

EF

\begin{tabular}{|l|l|}
\hline Name & US-Unemployment rate \\
\hline Units & Percent \\
\hline
\end{tabular}

EG

\begin{tabular}{|l|l|}
\hline Name & US-Broad money \\
\hline Units & Billions of US Dollar \\
\hline Comments & Prior to October 2001 data refer to M2 aggregate \\
\hline
\end{tabular}

$\mathrm{EH}$

\begin{tabular}{|l|l|}
\hline Name & JP-Consumer price index \\
\hline Units & Index, 2000 = 100 \\
\hline
\end{tabular}

EI

\begin{tabular}{|l|l|}
\hline Name & JP-Unit labour costs (manufacturing) \\
\hline Units & Index, $2000=100$ \\
\hline
\end{tabular}

EJ

\begin{tabular}{|l|l|}
\hline Name & JP-Industrial production index (manufacturing) \\
\hline Name & Index, $2000=100$ \\
\hline
\end{tabular}




EK
\begin{tabular}{|l|l|}
\hline Name & JP-Unemployment rate \\
\hline Units & Percent \\
\hline
\end{tabular}

EL

\begin{tabular}{|l|l|}
\hline Name & JP-Broad money \\
\hline Units & Billions of Japanese Yen \\
\hline
\end{tabular}

\section{Industry and commodity prices: by type of goods and by industry}

Industrial producer index

EM

EN

EO

EP

EQ

ER

ES

ET

EU

EV

EW

EX

EY
Industry excluding construction

Total (index)

Total (annual percentage changes)

Industry excluding construction and energy

Total (annual percentage changes)

Intermediate goods

Capital goods

Consumer goods

Total (annual percentage changes)

Durable

Non-durable

Energy -introduced in August 2001

Manufacturing

World market prices of raw materials

Total

Total excluding energy

Oil prices

EURO AREA CONCEPT

Since February 2009: Euro 16

March 2008 to January 2009: Euro 15

March 2007 to February 2008: Euro 13

January 2004 to February 2007: Euro 12

January 2001 to December 2003: Euro area changing composition (unless

otherwise indicated)

SEASONAL ADJUSTMENT

Since January 2001: No adjustment

ADDITIONAL NOTES

- Change of a base year from 1995 to 2000 in June 2003

- Data on industry excluding construction and energy (columns EM to ES) were introduced in August 2001 in combination with the new harmonised definition for the Main Industrial Groupings (MIGS)

- Methodological notes on the ECB's website: http://www.ecb.int/stats/prices/hicp/html/index.en.html 
SOURCE: Eurostat, HWWA, Thomson Financial Datastream and ECB

calculations

EM

\begin{tabular}{|l|l|}
\hline Name & $\begin{array}{l}\text { Producer Price Index, domestic sales, Total Industry (excluding } \\
\text { construction) }\end{array}$ \\
\hline $\begin{array}{l}\text { Euro area } \\
\text { concept }\end{array}$ & Since January 2001: Euro 12 \\
\hline
\end{tabular}

\section{EN}

\begin{tabular}{|l|l|}
\hline Name & $\begin{array}{l}\text { Producer Price Index, domestic sales, Total Industry (excluding } \\
\text { construction; annual percentage changes) }\end{array}$ \\
\hline Units & $\begin{array}{l}\text { Since January 2004: data available as index, } \\
\text { Since May 2001 to December 2003: data available as annual percentage } \\
\text { changes, } \\
\text { January 2001 to April 2001: data available as index }\end{array}$ \\
\hline
\end{tabular}

EO

\begin{tabular}{|l|l|}
\hline Name & $\begin{array}{l}\text { Producer Price Index, domestic sales, Total Industry excluding } \\
\text { construction and MIG Energy }\end{array}$ \\
\hline Units & $\begin{array}{l}\text { Since January 2004: data available as index, } \\
\text { August 2001 to December 2003: data available as annual percentage } \\
\text { changes }\end{array}$ \\
\hline Availability & Published since August 2001 (see additional note for the block) \\
\hline
\end{tabular}

EP

\begin{tabular}{|l|l|}
\hline Name & $\begin{array}{l}\text { Producer Price Index, domestic sales, MIG Intermediate Goods } \\
\text { Industry }\end{array}$ \\
\hline Units & $\begin{array}{l}\text { Since January 2004: data available as index, } \\
\text { May 2001 to December 2003: data available as annual percentage } \\
\text { changes, } \\
\text { January 2001 to April 2001: data available as index }\end{array}$ \\
\hline
\end{tabular}

EQ

\begin{tabular}{|l|l|}
\hline Name & Producer Price Index, domestic sales, MIG Capital Goods Industry \\
\hline Units & $\begin{array}{l}\text { Since January 2004: data available as index, } \\
\text { January 2001 to December 2003: data available as annual percentage } \\
\text { changes }\end{array}$ \\
\hline
\end{tabular}

ER

\begin{tabular}{|l|l|}
\hline Name & Producer Price Index, domestic sales, Consumer goods industry \\
\hline Units & $\begin{array}{l}\text { Since January 2004: data available as index, } \\
\text { May 2001 to December 2003: data available as annual percentage } \\
\text { changes, } \\
\text { March 2001 to April 2001: data available as index }\end{array}$ \\
\hline Availability & Since March 2001 \\
\hline
\end{tabular}


ES

\begin{tabular}{|l|l|}
\hline Name & $\begin{array}{l}\text { Producer Price Index, domestic sales, MIG Durable Consumer } \\
\text { Goods Industry }\end{array}$ \\
\hline Units & $\begin{array}{l}\text { Since January 2004: data available as index, } \\
\text { May 2001 to December 2003: data available as annual percentage } \\
\text { changes, } \\
\text { January 2001 to April 2001: data available as index }\end{array}$ \\
\hline
\end{tabular}

ET

\begin{tabular}{|l|l|}
\hline Name & $\begin{array}{l}\text { Producer Price Index, domestic sales, MIG Non-durable Consumer } \\
\text { Goods Industry }\end{array}$ \\
\hline Units & $\begin{array}{l}\text { Since January 2004: data available as index, } \\
\text { May 2001 to December 2003: data available as annual percentage } \\
\text { changes, } \\
\text { January 2001 to April 2001: data available as index }\end{array}$ \\
\hline
\end{tabular}

EU

\begin{tabular}{|l|l|}
\hline Name & Producer Price Index, domestic sales, MIG Energy \\
\hline Units & $\begin{array}{l}\text { Since January 2004: data available as index, } \\
\text { August 2001 to December 2003: data available as annual percentage } \\
\text { changes }\end{array}$ \\
\hline Availability & Published since August 2001 (see additional notes for the block) \\
\hline
\end{tabular}

EV

\begin{tabular}{|l|l|}
\hline Name & Producer Price Index, domestic sales, Manufacturing \\
\hline Units & $\begin{array}{l}\text { Since January 2004: data available as index, } \\
\text { May 2001 to December 2003: data available as annual percentage } \\
\text { changes, } \\
\text { January 2001 to April 2001: data available as index }\end{array}$ \\
\hline
\end{tabular}

EW

\begin{tabular}{|l|l|}
\hline Name & World market prices of raw materials, Index total , Euro \\
\hline $\begin{array}{l}\text { Euro area } \\
\text { concept }\end{array}$ & $\begin{array}{l}\text { Since January 2002: Euro 12 } \\
\text { January 2001 to December 2001: Extra Euro 12 }\end{array}$ \\
\hline
\end{tabular}

EX

\begin{tabular}{|l|l|}
\hline Name & $\begin{array}{l}\text { World market prices of raw materials, Index Total excluding } \\
\text { energy, Euro }\end{array}$ \\
\hline $\begin{array}{l}\text { Euro area } \\
\text { concept }\end{array}$ & $\begin{array}{l}\text { Since January 2002: Euro 12 } \\
\text { January 2001 to December 2001: Extra Euro 12 }\end{array}$ \\
\hline
\end{tabular}

EY

\begin{tabular}{|l|l|}
\hline Name & Brent Crude-1 Month Fwd,fob US\$/BBL converted in euro \\
\hline Units & EUR per barrel \\
\hline
\end{tabular}




\title{
Money supply M1 M2 M3, Base money, Total loans, Total credit (seasonally adjusted)
}

\author{
EZ M3 (annual growth rate) \\ FA M1 \\ FB M2 \\ FC M3 \\ FD Base money \\ FE Loans to other euro area residents \\ FF Credit to other euro area residents
}

EURO AREA CONCEPT

Since January 2001: Euro area changing composition

SEASONAL ADJUSTMENT

All data seasonally and working day adjusted

ADDITIONAL NOTES:

- All data expressed in millions of Euro

- Methodological notes on the ECB's website:

http://www.ecb.int/stats/money/aggregates/aggr/html/index.en.html

SOURCE: ECB

EZ

\begin{tabular}{|l|l|}
\hline Name & Monetary aggregate M3, annual growth rate
\end{tabular}

\begin{tabular}{l|l} 
Availability & Since August 2001 \\
\hline
\end{tabular}

FA

\begin{tabular}{|l|l|}
\hline Name & Monetary aggregate M1 \\
\hline
\end{tabular}

FB

\begin{tabular}{|l|l|}
\hline Name & Monetary aggregate M2 \\
\hline
\end{tabular}

FC

\begin{tabular}{|l|l}
\hline Name & Monetary aggregate M3 \\
\hline
\end{tabular}

FD

\begin{tabular}{|l|l|}
\hline Name & Base money \\
\hline Availability & Since April 2001 \\
\hline Comments & $\begin{array}{l}\text { The data refers to the month when maintenance period ended - no } \\
\text { maintenance period ended in February 2004, due to change in the } \\
\text { operational framework. }\end{array}$ \\
\hline
\end{tabular}


FE

\begin{tabular}{|l|l}
\hline Name & Loans to other euro area residents, \\
\hline
\end{tabular}

Availability Published since September 2003

FF

\begin{tabular}{|l|l|}
\hline Name & Credit to other euro area residents \\
\hline
\end{tabular}

Availability Published since September 2003

\section{Money supply M1 M2 M3, Base money, Total loans, Total credit} $\underline{\text { (non-seasonally adjusted) }}$

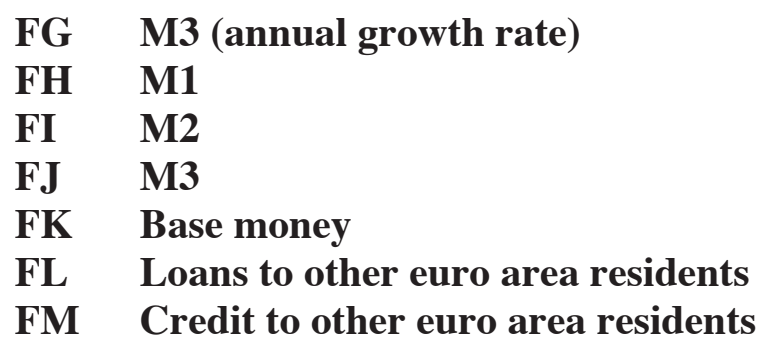

FG M3 (annual growth rate)

FH M1

FI M2

FJ M3

FK Base money

FL Loans to other euro area residents

FM Credit to other euro area residents

EURO AREA CONCEPT

Since January 2001: Euro area changing composition

SEASONAL ADJUSTMENT

All data non-seasonally adjusted

ADDITIONAL NOTES

- All data expressed in millions of Euro

- Methodological notes on the ECB's website:

http://www.ecb.int/stats/money/aggregates/aggr/html/index.en.html

SOURCE: ECB

FG

\begin{tabular}{|l|l}
\hline Name & Monetary aggregate M3, annual growth rate \\
\hline
\end{tabular}

$\mathrm{FH}$

\begin{tabular}{|l|l|}
\hline Name & Monetary aggregate M1
\end{tabular}

FI

\begin{tabular}{|l|l}
\hline Name & Monetary aggregate M2 \\
\hline
\end{tabular}

FJ

\begin{tabular}{|l|l}
\hline Name & Monetary aggregate M3
\end{tabular}


FK

\begin{tabular}{|l|l|}
\hline Name & Base money \\
\hline Availability & Since April 2001 \\
\hline Comments & $\begin{array}{l}\text { The data refers to the month when maintenance period ended - no } \\
\text { maintenance period ended in February 2004, due to change in the } \\
\text { operational framework. }\end{array}$ \\
\hline
\end{tabular}

FL

\begin{tabular}{|l|l}
\hline Name & Loans, Total maturity \\
\hline
\end{tabular}

Availability Published since September 2003

FM

\begin{tabular}{|l|l}
\hline Name & Credit to other euro area residents
\end{tabular}

Availability Published since September 2003

Confidence indicators: economic, manufacturing, consumer, construction, retail trade, services

FN Economic sentiment indicator

Manufacturing industry

FO

Industrial confidence indicator

FP

Total

FQ

Order books

FR

Stocks of finished products

Production expectations

FS

FT

FU

FV

FW

FX

FY

FZ

Consumer confidence indicator

GA

GB

GC

GD

GE

GF

Total

Financial situation over next 12 months

Economic situation over next 12 months

Unemployment situation over next 12 months

Savings over next 12 months

Construction confidence indicator

Total

Order books

Employment expectations

Retail trade confidence indicator

Total

Present business situation

Volume of stocks

Expected business situation

Services confidence indicator

GG Demand in recent months

GH Demand in the months ahead 
EURO AREA CONCEPT

Since February 2009: Euro 16

February 2008 to January 2009: Euro 15

February 2007 to January 2008: Euro 13

January 2001 to January 2007: Euro 12, unless otherwise indicated

ADDITIONAL NOTES

- All data expressed as percentage balances

SOURCE: European Commission: DG ECFIN

FN

\begin{tabular}{|l|l|}
\hline Name & Economic Sentiment Indicator \\
\hline Units & Index \\
\hline Availability & Since February 2002 \\
\hline Comments & $\begin{array}{l}\text { Economic sentiment indicator (ESI) is a composite indicator calculated } \\
\text { as the weighted average of the components of the confidence indicators } \\
\text { for industry (weight: 40\%), services (weight 30\%), consumers (weight: } \\
\text { 20\%), construction (weight 5\%) and retail trade (weight: 5\%). A mean } \\
\text { index level has been imposed by setting the long-term average of the } \\
\text { ESI to 100; a reading of the ESI of above (below) } 100 \text { indicates an } \\
\text { above (below) average economic sentiment. } \\
\text { DG ECFIN changed the components/weighting of this composite } \\
\text { indicator from reporting period May 2004 and September 2001 } \\
\text { onwards; data have been recalculated accordingly by DG ECFIN. Since } \\
\text { the reporting period May 2004, the indicator is no more an index with } \\
\text { base year =100, but with long-term average = 100 }\end{array}$ \\
\hline
\end{tabular}

FO

\begin{tabular}{|l|l|}
\hline Name & Industry Survey: Industrial Confidence Indicator \\
\hline Availability & Since January 2001 \\
\hline $\begin{array}{l}\text { Euro area } \\
\text { concept }\end{array}$ & $\begin{array}{l}\text { Since March 2001: Euro 12 } \\
\text { January 2001- February 2001: Euro area changing composition }\end{array}$ \\
\hline Comments & $\begin{array}{l}\text { Confidence indicator calculated as arithmetic average of the answers to } \\
\text { the questions on order books, stocks of finished goods (inverted sign) } \\
\text { and production expectations. }\end{array}$ \\
\hline
\end{tabular}

FP

\begin{tabular}{|l|l|}
\hline Name & Industry Survey: Assessment of order-book levels \\
\hline Availability & Since January 2001 \\
\hline $\begin{array}{l}\text { Euro area } \\
\text { concept }\end{array}$ & $\begin{array}{l}\text { Since March 2001: Euro 12 } \\
\text { January 2001- February 2001: Euro area changing composition }\end{array}$ \\
\hline
\end{tabular}

FQ

\begin{tabular}{|l|l|l}
\hline Name & Industry Survey: Assessment of stocks of finished products
\end{tabular}

Availability Since February 2002 
FR

\begin{tabular}{|l|l|}
\hline Name & Industry Survey: Production expectations for the months ahead \\
\hline Availability & Since January 2001 \\
\hline
\end{tabular}

FS

\begin{tabular}{|l|l|}
\hline Name & Consumer Survey: Consumer Confidence Indicator \\
\hline Availability & Since January 2001 \\
\hline Comments & $\begin{array}{l}\text { Consumer Confidence indicator calculated as the arithmetic average of } \\
\text { the answers to the questions on (1) the financial situation of the } \\
\text { household over the next } 12 \text { months; (2) the general economic situation } \\
\text { over the next } 12 \text { months; (3) the unemployment expectations over the } \\
\text { next } 12 \text { months; and, (4) savings over the next } 12 \text { months. } \\
\text { DG ECFIN changed the components of this composite indicator from } \\
\text { reporting period September 2001 onwards; data have been recalculated } \\
\text { accordingly by DG ECFIN }\end{array}$ \\
\hline
\end{tabular}

FT

\begin{tabular}{|l|l|}
\hline Name & Consumer Survey: Financial situation over next 12 months \\
\hline Avalability & Since Fer
\end{tabular}

Availability Since February 2002

FU

\begin{tabular}{|l|l|}
\hline Name & Consumer Survey: General economic situation over next 12 months \\
\hline Availabilty & Since Februry 2002 \\
\hline
\end{tabular}

Availability Since February 2002

FV

\begin{tabular}{|l|l|}
\hline Name & $\begin{array}{l}\text { Consumer Survey: Unemployment expectations over next } 12 \\
\text { months }\end{array}$ \\
\hline Availability & Since February 2002 \\
\hline
\end{tabular}

FW

\begin{tabular}{|l|l|}
\hline Name & Consumer Survey: Savings over next 12 months \\
\hline Availability & Since February 2002 \\
\hline Comments & Percentage balances \\
\hline
\end{tabular}

FX

\begin{tabular}{|l|l|}
\hline Name & Construction Survey: Construction Confidence Indicator \\
\hline Availability & Since January 2001 \\
\hline $\begin{array}{l}\text { Euro area } \\
\text { concept }\end{array}$ & $\begin{array}{l}\text { Since March 2001: Euro 12 } \\
\text { January 2001- February 2001: Euro area changing composition }\end{array}$ \\
\hline Comments & $\begin{array}{l}\text { Confidence indicator calculated as arithmetic average of the answers to } \\
\text { the questions on order books and employment expectations. - } \\
\text { Percentage balances }\end{array}$ \\
\hline
\end{tabular}

FY

\begin{tabular}{|l|l|}
\hline Name & Construction Survey: Assessment of order books \\
\hline Availability & Published since February 2002 \\
\hline
\end{tabular}


FZ

\begin{tabular}{|l|l|}
\hline Name & $\begin{array}{l}\text { Construction Survey: Employment expectations for the months } \\
\text { ahead }\end{array}$ \\
\hline Availability & Published since February 2002 \\
\hline
\end{tabular}

GA

\begin{tabular}{|l|l|}
\hline Name & Retail Trade Survey: Retail Confidence Indicator \\
\hline Availability & Since January 2001 \\
\hline $\begin{array}{l}\text { Euro area } \\
\text { concept }\end{array}$ & $\begin{array}{l}\text { Since March 2001: Euro 12 } \\
\text { January 2001- February 2001: Euro area changing composition }\end{array}$ \\
\hline Comments & $\begin{array}{l}\text { Confidence indicator calculated as arithmetic average of the answers to } \\
\text { the questions on present and expected business situation and on } \\
\text { assessment of stocks (inverted sign). }\end{array}$ \\
\hline
\end{tabular}

GB

\begin{tabular}{|l|l} 
Name & Retail Trade Survey: Present business situation
\end{tabular}

Availability Since January 2001

GC

\begin{tabular}{|l|l|}
\hline Name & Retail Trade Survey: Assessment of stocks
\end{tabular}

Availability Since January 2001

GD

\begin{tabular}{|l|l|}
\hline Name & Retail Trade Survey: Expected business situation \\
\hline Availability & Since February 2002 \\
\hline
\end{tabular}

GE

\begin{tabular}{|l|l|} 
Name & Service Survey: Service Confidence Indicator \\
\hline Availability & Since
\end{tabular}

Availability Since February 2002

Comments Confidence indicator calculated as arithmetic average of the answers to the question on assessment of business climate, evolution of demand in recent months and in the months ahead.

GF

\begin{tabular}{|l|l|}
\hline Name & Service Survey: Assessment of the business climate
\end{tabular}

Availability Since February 2002

GG

\begin{tabular}{|l|l|}
\hline Name & Service Survey: Evolution of demand in recent months \\
\hline Availability & Since February 2002 \\
\hline
\end{tabular}

GH

\begin{tabular}{|l|l|} 
Name & Service Survey: Evolution of demand expected in the months ahead \\
\hline
\end{tabular}

$\begin{array}{ll}\text { Availability } & \text { Since February } 2001\end{array}$ 


\title{
Overview of quarterly indicators
}

\begin{tabular}{|l|l|}
\hline $\begin{array}{c}\text { Columns in } \\
\text { the files }\end{array}$ & \multicolumn{1}{c|}{ Block name } \\
\hline B-K & Employment: by employment status, by economic activity \\
\hline L-R & GDP deflators: by expenditure components \\
\hline S-Y & Unit labour cost: by economic activity \\
\hline Z-AF & Hourly labour cost: by components and by economic activity \\
\hline AG & Exchange rates: effective exchange rates \\
\hline AH-BD & US and Japan: main economic and financial indicators \\
\hline BE & Industry and commodity prices: by type of goods and by industry \\
\hline BF-BL & GDP: by expenditure components at current prices \\
\hline BM-BS & GDP: by expenditure components at constant prices \\
\hline BT-CB & Value added: by economic activity at current prices \\
\hline CC-CK & Value added: by economic activity at constant prices \\
\hline CL & $\begin{array}{l}\text { Confidence indicators: economic, manufacturing, consumer, } \\
\text { construction, retail trade, services }\end{array}$ \\
\hline
\end{tabular}

\section{Employment: by employment status, by economic activity}

\author{
Whole economy \\ B Total (millions (s.a.)) \\ C Total (annual percentage changes) \\ By employment status \\ D Employees \\ E Self-employed \\ By economic activity \\ F Agriculture, hunting, forestry and fishing \\ G Mining, manufacturing and energy \\ H Construction \\ I Trade, repairs, hotels and restaurants, transport and \\ communication \\ J Financial, real estate, renting and business services \\ K Public administration, education, health and other services
}

SOURCE: Eurostat

B

\begin{tabular}{|l|l|}
\hline Name & Total employment \\
\hline Units & $\begin{array}{l}\text { Since August 2002 data in Thousands of Persons, } \\
\text { March 2001 to July 2002 data available as index }(2000=100)\end{array}$ \\
\hline $\begin{array}{l}\text { Euro area } \\
\text { concept }\end{array}$ & $\begin{array}{l}\text { Since February 2009: Euro 16 } \\
\text { July 2008 to January 2009: Euro 15, } \\
\text { June 2007 to June 2008: Euro 13, }\end{array}$ \\
\hline
\end{tabular}




\begin{tabular}{|l|l|}
\hline & $\begin{array}{l}\text { August 2002 to May 2007: Euro 12, } \\
\text { March 2001 to July 2002: Euro area changing composition }\end{array}$ \\
\hline Adjustment & Seasonally adjusted by mixed methods \\
\hline Availability & Since March 2001 \\
\hline
\end{tabular}

\section{C}

\begin{tabular}{|l|l|}
\hline Name & Total employment \\
\hline Units & $\begin{array}{l}\text { Since August 2002 data in Thousands of Persons, } \\
\text { March 2001 to July 2002 data available as index }(2000=100)\end{array}$ \\
\hline $\begin{array}{l}\text { Euro area } \\
\text { concept }\end{array}$ & $\begin{array}{l}\text { Since February 2009: Euro 16 } \\
\text { July 2008 to January 2009: Euro 15, } \\
\text { June 2007 to June 2008: Euro 13, } \\
\text { August 2002 to May 2007: Euro 12, } \\
\text { March 2001 to July 2002: Euro area changing composition }\end{array}$ \\
\hline Adjustment & $\begin{array}{l}\text { Since January 2004: no adjustment, } \\
\text { March 2001 to December 2003: seasonally adjusted by mixed methods }\end{array}$ \\
\hline Availability & Since March 2001 \\
\hline
\end{tabular}

D

\begin{tabular}{|l|l|}
\hline Name & Employees \\
\hline Units & $\begin{array}{l}\text { Since August 2002 data in Thousands of Persons } \\
\text { March 2001 to July 2002 data available as index }(2000=100)\end{array}$ \\
\hline $\begin{array}{l}\text { Euro area } \\
\text { concept }\end{array}$ & $\begin{array}{l}\text { Since February 2009: Euro 16 } \\
\text { July 2008 to January 2009: Euro 15, } \\
\text { June 2007 to June 2008: Euro 13, } \\
\text { August 2002 to May 2007: Euro 12, } \\
\text { March 2001 to July 2002: Euro 11 }\end{array}$ \\
\hline Adjustment & $\begin{array}{l}\text { Since January 2004: no adjustment } \\
\text { March 2001 to December 2003: seasonally adjusted by mixed methods }\end{array}$ \\
\hline Availability & Since March 2001 \\
\hline
\end{tabular}

E

\begin{tabular}{|l|l|}
\hline Name & Self-employed \\
\hline Units & $\begin{array}{l}\text { Since August 2002 data in Thousands of Persons } \\
\text { March 2001 to July 2002 data available as index }(2000=100)\end{array}$ \\
\hline $\begin{array}{l}\text { Euro area } \\
\text { concept }\end{array}$ & $\begin{array}{l}\text { Since February 2009: Euro 16 } \\
\text { July 2008 to January 2009: Euro 15, } \\
\text { June 2007 to June 2008: Euro 13, } \\
\text { August 2002 to May 2007: Euro 12, } \\
\text { March 2001 to July 2002: Euro area changing composition }\end{array}$ \\
\hline Adjustment & $\begin{array}{l}\text { Since January 2004: no adjustment } \\
\text { March 2001 to December 2003: seasonally adjusted by mixed methods }\end{array}$ \\
\hline Availability & Since March 2001 \\
\hline
\end{tabular}




F
\begin{tabular}{|l|l|}
\hline Name & $\begin{array}{l}\text { Total employment: agricultural hunting forestry and fishing } \\
\text { products }\end{array}$ \\
\hline Units & Thousands of Persons \\
\hline $\begin{array}{l}\text { Euro area } \\
\text { concept }\end{array}$ & $\begin{array}{l}\text { Since February 2009: Euro 16 } \\
\text { July 2008 to January 2009: Euro 15, } \\
\text { June 2007 to June 2008: Euro 13, } \\
\text { March 2003 to May 2007: Euro 12 }\end{array}$ \\
\hline Adjustment & $\begin{array}{l}\text { Since January 2004: no adjustment } \\
\text { March 2003 to December 2003: seasonally adjusted by mixed methods }\end{array}$ \\
\hline Availability & Since March 2003 \\
\hline
\end{tabular}

G

\begin{tabular}{|l|l|}
\hline Name & Total employment: total industry \\
\hline Units & Thousands of Persons \\
\hline $\begin{array}{l}\text { Euro area } \\
\text { concept }\end{array}$ & $\begin{array}{l}\text { Since February 2009: Euro 16 } \\
\text { July 2008 to January 2009: Euro 15, } \\
\text { June 2007 to June 2008: Euro 13, } \\
\text { March 2003 to May 2007: Euro 12 }\end{array}$ \\
\hline Adjustment & $\begin{array}{l}\text { Since January 2004: no adjustment } \\
\text { March 2003 to December 2003: seasonally adjusted by mixed methods }\end{array}$ \\
\hline Availability & Since March 2003 \\
\hline
\end{tabular}

$\mathrm{H}$

\begin{tabular}{|l|l|}
\hline Name & Total employment: construction \\
\hline Units & Thousands of Persons \\
\hline $\begin{array}{l}\text { Euro area } \\
\text { concept }\end{array}$ & $\begin{array}{l}\text { Since February 2009: Euro 16 } \\
\text { July 2008 to January 2009: Euro 15, } \\
\text { June 2007 to June 2008: Euro 13, } \\
\text { March 2003 to May 2007: Euro 12 }\end{array}$ \\
\hline Adjustment & $\begin{array}{l}\text { Since January 2004: no adjustment } \\
\text { March 2003 to December 2003: seasonally adjusted by mixed methods }\end{array}$ \\
\hline Availability & Since March 2003 \\
\hline
\end{tabular}

I

\begin{tabular}{|l|l|}
\hline Name & $\begin{array}{l}\text { Total employment: trade, repairs, hotels, restaurants, transport } \\
\text { and communication }\end{array}$ \\
\hline Units & Thousands of Persons \\
\hline $\begin{array}{l}\text { Euro area } \\
\text { concept }\end{array}$ & $\begin{array}{l}\text { Since February 2009: Euro 16 } \\
\text { July 2008 to January 2009: Euro 15, } \\
\text { June 2007 to June 2008: Euro 13, } \\
\text { March 2003 to May 2007: Euro 12 }\end{array}$ \\
\hline Adjustment & $\begin{array}{l}\text { Since January 2004: no adjustment } \\
\text { March 2003 to December 2003: seasonally adjusted by mixed methods }\end{array}$ \\
\hline Availability & Since March 2003 \\
\hline
\end{tabular}




\begin{tabular}{|c|c|}
\hline \multicolumn{2}{|l|}{$\mathbf{J}$} \\
\hline Name & Total employment: financial intermediation, real estate \\
\hline Units & Thousands of Persons \\
\hline $\begin{array}{l}\text { Euro area } \\
\text { concept }\end{array}$ & $\begin{array}{l}\text { Since February 2009: Euro } 16 \\
\text { July } 2008 \text { to January 2009: Euro 15, } \\
\text { June } 2007 \text { to June 2008: Euro } 13 \text {, } \\
\text { March } 2003 \text { to May 2007: Euro } 12\end{array}$ \\
\hline Adjustment & $\begin{array}{l}\text { Since January 2004: no adjustment } \\
\text { March } 2003 \text { to December 2003: seasonally adjusted by mixed methods }\end{array}$ \\
\hline Availability & Since March 2003 \\
\hline \multicolumn{2}{|l|}{ K } \\
\hline Name & Total employment: other services \\
\hline Units & Thousands of Persons \\
\hline $\begin{array}{l}\text { Euro area } \\
\text { concept }\end{array}$ & $\begin{array}{l}\text { Since February 2009: Euro } 16 \\
\text { July } 2008 \text { to January 2009: Euro } 15 \text {, } \\
\text { June } 2007 \text { to June 2008: Euro 13, } \\
\text { March } 2003 \text { to May 2007: Euro } 12\end{array}$ \\
\hline Adjustment & $\begin{array}{l}\text { Since January 2004: no adjustment } \\
\text { March } 2003 \text { to December 2003: seasonally adjusted by mixed methods }\end{array}$ \\
\hline Availability & Since March 2003 \\
\hline
\end{tabular}

\section{GDP deflators: by expenditure components}

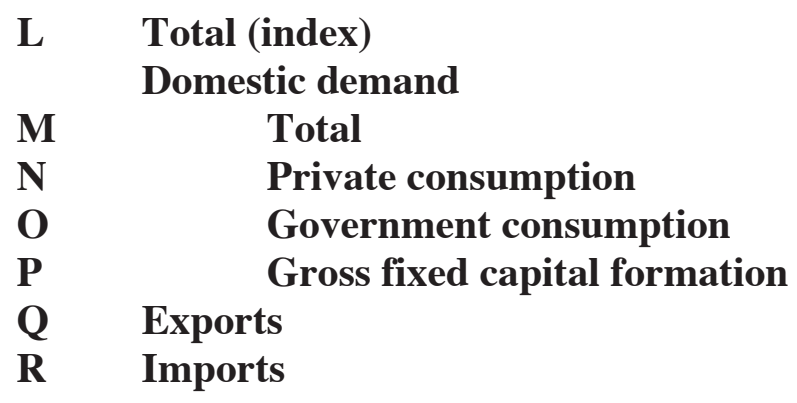

L Total (index)

Domestic demand

M Total

N Private consumption

O Government consumption

$P \quad$ Gross fixed capital formation

Q Exports

R Imports

\section{EURO AREA CONCEPT}

Since February 2009: Euro 16

June 2008 to January 2009: Euro 15

June 2007 to June May 2008: Euro 13

January 2001 to May 2007: Euro 12

SEASONAL ADJUSTMENT

All data seasonally adjusted by mixed methods

\section{ADDITIONAL NOTES}

- All data available as indexes

- Change of a base year from 1995 to 2000 only for the vintage January 2004 
$\mathrm{L}$

\begin{tabular}{|l|l|}
\hline Name & Gross domestic product at market price - Deflator (ECB
\end{tabular} compilation) - Euro (estimated)

M

\begin{tabular}{|l|l|l|l|l|}
\hline Name & Domestic demand including stocks - Deflator (ECB compilation) -
\end{tabular} Euro (estimated)

$\mathrm{N}$

\begin{tabular}{|l|l} 
Name & Final consumption of households and NPISH's (private
\end{tabular} consumption) - Deflator (ECB compilation) - Euro (estimated)

$\mathrm{O}$

\begin{tabular}{|l|l|}
\hline Name & Final consumption of general government - Deflator (ECB
\end{tabular} compilation) - Euro (estimated)

$\mathrm{P}$

\begin{tabular}{|l|l|}
\hline Name & Gross fixed capital formation - Deflator (ECB compilation) - Euro
\end{tabular} (estimated)

Q

\begin{tabular}{|l|l|}
\hline Name & Exports of goods and services - Deflator (ECB compilation) - Euro
\end{tabular} (estimated)

$\mathrm{R}$

\begin{tabular}{|l|l|}
\hline Name & Import of goods and services - Deflator (ECB compilation) - Euro \\
\hline
\end{tabular} (estimated)

\section{Unit labour cost: by economic activity}

S Total (index)

By economic activity

T Agriculture, hunting, forestry and fishing

U Mining, manufacturing and energy

V Construction

W Trade, repairs, hotels and restaurants, transport and communication

$\mathrm{X} \quad$ Financial, real estate, renting and business services

Y Public administration, education, health and other services 
EURO AREA CONCEPT

Since February 2009: Euro 16

July 2008 to January 2009: Euro 15

June 2007 to June 2008: Euro 13

January 2001 to May 2007: Euro 12

SEASONAL ADJUSTMENT

All data seasonally adjusted

\section{ADDITIONAL NOTES}

- All data available as indices

- Change of a base year from 1995 to 2000 in August 2003

- For the vintages since March 2003 onwards: data before 2001 corrected for exchange rate effects, GDP data used in the calculation of the series are re-scaled to 1995

SOURCE: ECB calculations based on Eurostat data

\section{$\mathrm{S}$}

\begin{tabular}{|l|l|}
\hline Name & Unit Labour Costs - Total \\
\hline $\begin{array}{l}\text { Euro area } \\
\text { concept }\end{array}$ & $\begin{array}{l}\text { Since June 2007: Euro 13, } \\
\text { March 2003 to May 2007: Euro 12, } \\
\text { January 2001 to February 2003: Euro area changing composition }\end{array}$ \\
\hline Comments & Change of a base period from 1980=100 to 1985=100 in July 2001 \\
\hline
\end{tabular}

$\mathrm{T}$

\begin{tabular}{|l|l|}
\hline Name & Unit Labour Costs - Agriculture, hunting, forestry, and fishing \\
\hline
\end{tabular}

Availability Published since March 2003

$\mathrm{U}$

\begin{tabular}{|l|l|}
\hline Name & Unit Labour Costs - Industry, including energy \\
\hline Availability & Published since March 2003 \\
\hline
\end{tabular}

$\mathrm{V}$

\begin{tabular}{|l|l|}
\hline Name & Unit Labour Costs - Construction \\
\hline Availability & Published since March 2003 \\
\hline
\end{tabular}

W

\begin{tabular}{|l|l|}
\hline Name & $\begin{array}{l}\text { Unit Labour Costs - Trade, repairs, hotels, restaurants, transport } \\
\text { and communications }\end{array}$ \\
\hline Availability & Published since March 2003 \\
\hline
\end{tabular}

$\mathrm{X}$

\begin{tabular}{|l|l|}
\hline Name & $\begin{array}{l}\text { Unit Labour Costs - Financial, real estate, renting and business } \\
\text { activities }\end{array}$ \\
\hline Availability & Published since March 2003 \\
\hline
\end{tabular}


\begin{tabular}{|l|l}
\hline Name & Unit Labour Costs - Other service activities
\end{tabular}

Availability Published since March 2003

\section{Hourly labour cost: by components and by economic activity}

\section{Z Total (index)}

AA Wages and salaries

AB Employers' social contributions

By selected economic activity

AC Mining, manufacturing and energy

AD Construction

AE Services

AF Memo item: indicator of negotiated wages

EURO AREA CONCEPT

Since January 2001: Euro area changing composition

ADDITIONAL NOTES

- Change of a base year from 1995 to 2000 in August 2003

SOURCE: Eurostat and ECB calculations based on Eurostat data

\section{Z}

\begin{tabular}{|l|l|}
\hline Name & $\begin{array}{l}\text { Hourly Labour cost index - total, Whole economy excluding } \\
\text { agriculture, fishing and government sectors }\end{array}$ \\
\hline Adjustment & Working day and seasonally adjusted \\
\hline
\end{tabular}

AA

\begin{tabular}{|l|c|}
\hline Name & $\begin{array}{c}\text { Hourly Labour cost index - total, Whole economy excluding } \\
\text { agriculture, fishing and government sectors }\end{array}$ \\
\hline Adjustment & Working day adjusted, not seasonally adjusted \\
\hline
\end{tabular}

$\mathrm{AB}$

\begin{tabular}{|l|l|}
\hline Name & Hourly Labour cost index - wages and salaries, Whole economy
\end{tabular} excluding agriculture, fishing and government sectors

Adjustment Since February 2002: not adjusted, January 2001 to January 2002: seasonally adjusted, not working day adjusted

$\mathrm{AC}$

\begin{tabular}{|l|l|}
\hline Name & Hourly Labour cost index - costs other than wages and salaries,
\end{tabular} Whole economy excluding agriculture, fishing and government sectors

\begin{tabular}{l|l} 
Adjustment & Since February 2002: not adjusted,
\end{tabular} 
January 2001 to January 2002: seasonally adjusted, not working day adjusted

AD

\begin{tabular}{|l|l|}
\hline Name & $\begin{array}{l}\text { Hourly Labour cost index - total, Total Industry (excluding } \\
\text { construction) }\end{array}$ \\
\hline Adjustment & $\begin{array}{l}\text { Since February 2002: not adjusted. } \\
\text { January 2001 to January 2002: seasonally adjusted, not working day } \\
\text { adjusted }\end{array}$ \\
\hline
\end{tabular}

$\mathrm{AE}$

\begin{tabular}{|l|l|}
\hline Name & Hourly Labour cost index - total, Construction \\
\hline
\end{tabular}

\begin{tabular}{|l|l|}
\hline Adjustment & Not adjusted \\
\hline
\end{tabular}

\begin{tabular}{|c|c|}
\hline Name & $\begin{array}{l}\text { Hourly Labour cost index - total, Services (NACE rev 1. Sectors G } \\
\text { to } \mathrm{K} \text { ) }\end{array}$ \\
\hline Adjustment & $\begin{array}{l}\text { Since February 2002: not adjusted, } \\
\text { January } 2001 \text { to January 2002: Seasonally adjusted, not working day } \\
\text { adjusted }\end{array}$ \\
\hline Unit & $\begin{array}{l}\text { Since April } 2001 \text { data available as an index. } \\
\text { January } 2001 \text { to March } 2001 \text { data available as annual percentage } \\
\text { change }\end{array}$ \\
\hline
\end{tabular}

\section{ECB Real effective exch. rate ULC total economy deflated, EER-12 group of currencies against Euro}

\section{ADDITIONAL NOTES}

- Data available as index $(99 \mathrm{Q} 1=100)$

- February 2009: new definition of a narrow group

- February 2008: new definition of a narrow group

- February 2007: new definition of a narrow group

- September 2004: new definition of a narrow group

- Methodological notes on the ECB's website: http://www.ecb.int/stats/exchange/eurofxref/html/index.en.html

- See also the documentation of monthly variables

SOURCE: ECB

AG

Name ECB Real effective exch. rate ULC total economy deflated, EER-12 group of currencies against Euro

Availability Published since August 2003 


\section{US and Japan: main economic and financial indicators}

AH
\begin{tabular}{|l|l|}
\hline Name & US- UNIT LABOR COSTS IN MANUFACTURING - INDEX SA \\
\hline Units & Index, $1992=100$ \\
\hline Source & BIS \\
\hline
\end{tabular}

AI
\begin{tabular}{|l|l|}
\hline Name & US- GDP, AT MARKET PRICES - CHAINED 2000 USD SAAR \\
\hline Units & Billions of Chained 2000 US Dollar \\
\hline Source & BIS \\
\hline
\end{tabular}

AJ
\begin{tabular}{|l|l|}
\hline Name & $\begin{array}{l}\text { United States - Deficit or surplus - All sectors/ unspecified/ not } \\
\text { applicable (ESA95)-NCBs - General government (ESA95)-NCBs - } \\
\text { Non-financial flows current prices - Percentage points, } \\
\text { series(t)/GDP(t) - Neither seasonally or working day adjusted }\end{array}$ \\
\hline Availability & Since February 2001 \\
\hline Source & BIS \\
\hline
\end{tabular}

AK
\begin{tabular}{|l|l|}
\hline Name & $\begin{array}{l}\text { United States - Maastricht assets/liabilities - General government } \\
\text { (ESA95)-NCBs - All sectors without GG (consolidation) (ESA95)- } \\
\text { NCBs - Financial stocks - ESA 79 / Maastricht valuation - } \\
\text { Percentage points, series(t)/GDP(t) - Neither seasonally or working } \\
\text { day adjusted }\end{array}$ \\
\hline Availability & Since February 2001 \\
\hline Source & BIS \\
\hline
\end{tabular}

AL
\begin{tabular}{|l|l|}
\hline Name & JP- GDP, AT MARKET PRICES (SNA 93) - 1995 PR. NSA \\
\hline Units & Billions of Chained 2000 Japanese Yen \\
\hline Source & BIS \\
\hline
\end{tabular}

\begin{tabular}{|l|l|} 
AM & $\begin{array}{l}\text { United States, Gross saving, Transaction as a percentage of GDP - } \\
\text { United States Total economy (debtor); World not allocated } \\
\text { (geographically) Not applicable (creditor), ESA95 valuation, } \\
\text { Neither seasonally or working day adjusted }\end{array}$ \\
\hline Source & Federal Reserve Board \\
\hline
\end{tabular}

\begin{tabular}{|c|c|}
\hline Name & $\begin{array}{l}\text { United States, Gross capital formation, Transaction as a } \\
\text { percentage of GDP - World not allocated (geographically) Not } \\
\text { applicable (debtor); United States Total economy (creditor), ESA95 } \\
\text { valuation, Neither seasonally or working day adjusted }\end{array}$ \\
\hline Source & Federal Reserve Board \\
\hline
\end{tabular}




\begin{tabular}{|l|l|}
\multicolumn{1}{|l}{ AO } & $\begin{array}{l}\text { United States, Balancing items, capital accounts, Transaction as a } \\
\text { percentage of GDP - United States Total economy (debtor); World } \\
\text { (all entities) Total economy (creditor), ESA95 valuation, Neither } \\
\text { seasonally or working day adjusted }\end{array}$ \\
\hline Source & Federal Reserve Board \\
\hline
\end{tabular}

\begin{tabular}{l|l|} 
AP & \multicolumn{1}{|l|}{\begin{tabular}{|l|} 
Name \\
United States, Gross capital formation, Transaction as a \\
percentage of GDP - World not allocated (geographically) Not \\
applicable (debtor); United States Corporate business (creditor), \\
ESA95 valuation, Neither seasonally or working day adjusted
\end{tabular}} \\
\hline Source & Federal Reserve Board \\
\hline
\end{tabular}

\begin{tabular}{|c|c|}
\hline Name & $\begin{array}{l}\text { United States, Total, financial instruments, Transaction as a } \\
\text { percentage of GDP - World (all entities) Total economy (debtor); } \\
\text { United States Corporate business (creditor), ESA95 valuation, } \\
\text { Neither seasonally or working day adjusted }\end{array}$ \\
\hline Source & Federal Reserve Board \\
\hline
\end{tabular}

\begin{tabular}{|c|c|}
\hline Name & $\begin{array}{l}\text { United States, Gross saving, Transaction as a percentage of GDP - } \\
\text { United States Corporate business (debtor); World not allocated } \\
\text { (geographically) Not applicable (creditor), ESA95 valuation, } \\
\text { Neither seasonally or working day adjusted }\end{array}$ \\
\hline Source & Federal Reserve Board \\
\hline
\end{tabular}

\begin{tabular}{|c|c|}
\hline Name & $\begin{array}{l}\text { United States, Total, financial instruments, Transaction as a } \\
\text { percentage of GDP - United States Corporate business (debtor); } \\
\text { World (all entities) Total economy (creditor), ESA95 valuation, } \\
\text { Neither seasonally or working day adjusted }\end{array}$ \\
\hline Source & Federal Reserve Board \\
\hline
\end{tabular}

AT
\begin{tabular}{|l|l|}
\hline Name & $\begin{array}{l}\text { United States, Capital expenditures, Transaction as a percentage } \\
\text { of GDP - World not allocated (geographically) Not applicable } \\
\text { (debtor); United States Household, Non-profit institutions serving } \\
\text { households (creditor), ESA95 valuation, Neither seasonally or } \\
\text { working day adjusted }\end{array}$ \\
\hline Source & Federal Reserve Board \\
\hline
\end{tabular}

AU

\begin{tabular}{|l|l|}
\hline Name & $\begin{array}{l}\text { United States, Total, financial instruments, Transaction as a } \\
\text { percentage of GDP - World (all entities) Total economy (debtor); } \\
\text { United States Household, Non-profit institutions serving } \\
\text { households (creditor), ESA95 valuation, Neither seasonally or }\end{array}$ \\
\hline
\end{tabular}




\begin{tabular}{|l|l|}
\hline & working day adjusted \\
\hline Source & Federal Reserve Board \\
\hline
\end{tabular}

AV
\begin{tabular}{|l|l|}
\hline Name & $\begin{array}{l}\text { United States, Gross saving and expenditures in consumer } \\
\text { durables, Transaction as a percentage of GDP - United States } \\
\text { Household, Non-profit institutions serving households (debtor); } \\
\text { World not allocated (geographically) Not applicable (creditor), } \\
\text { ESA95 valuation, Neither seasonally or working day adjusted }\end{array}$ \\
\hline Source & Federal Reserve Board \\
\hline
\end{tabular}

AW
\begin{tabular}{|l|l|}
\hline Name & $\begin{array}{l}\text { United States, Total, financial instruments, Transaction as a } \\
\text { percentage of GDP - United States Household, Non-profit } \\
\text { institutions serving households (debtor); World (all entities) Total } \\
\text { economy (creditor), ESA95 valuation, Neither seasonally or } \\
\text { working day adjusted }\end{array}$ \\
\hline Source & Federal Reserve Board \\
\hline
\end{tabular}

AX
\begin{tabular}{|l|l|}
\hline Name & $\begin{array}{l}\text { Japan, Gross saving, Transaction as a percentage of GDP - Japan } \\
\text { Total economy (debtor); World not allocated (geographically) Not } \\
\text { applicable (creditor), ESA95 valuation, Neither seasonally or } \\
\text { working day adjusted }\end{array}$ \\
\hline Availability & Published since July 2002 \\
\hline Source & Bank of Japan \\
\hline
\end{tabular}

AY
\begin{tabular}{|l|l|}
\hline Name & $\begin{array}{l}\text { Japan, Gross capital formation, Transaction as a percentage of } \\
\text { GDP - World not allocated (geographically) Not applicable } \\
\text { (debtor); Japan Total economy (creditor), ESA95 valuation, } \\
\text { Neither seasonally or working day adjusted }\end{array}$ \\
\hline Availability & Since January 2001, no data in October 2001. \\
\hline Source & Bank of Japan \\
\hline
\end{tabular}

AZ
\begin{tabular}{|l|l|}
\hline Name & $\begin{array}{l}\text { Japan, Balancing items, capital accounts, Transaction as a } \\
\text { percentage of GDP - Japan Total economy (debtor); World (all } \\
\text { entities) Total economy (creditor), ESA95 valuation, Neither } \\
\text { seasonally or working day adjusted }\end{array}$ \\
\hline Availability & Published since July 2002 \\
\hline Source & Bank of Japan \\
\hline
\end{tabular}

BA
\begin{tabular}{|l|l|}
\hline Name & $\begin{array}{l}\text { Japan, Total, financial instruments, Transaction as a percentage of } \\
\text { GDP - World (all entities) Total economy (debtor); Japan Non- } \\
\text { financial corporations (creditor), ESA95 valuation, Neither } \\
\text { seasonally or working day adjusted }\end{array}$ \\
\hline
\end{tabular}




\begin{tabular}{|l|l|}
\hline Availability & Since January 2001, no data in October 2001. \\
\hline Source & Bank of Japan \\
\hline
\end{tabular}

$\mathrm{BB}$

\begin{tabular}{|l|l|}
\hline Name & $\begin{array}{l}\text { Japan, Total, financial instruments, Transaction as a percentage of } \\
\text { GDP - Japan Non-financial corporations (debtor); World (all } \\
\text { entities) Total economy (creditor), ESA95 valuation, Neither } \\
\text { seasonally or working day adjusted }\end{array}$ \\
\hline Availability & Since January 2001, no data in Oct 01. \\
\hline Source & Bank of Japan \\
\hline
\end{tabular}

$\mathrm{BC}$

\begin{tabular}{|l|l|}
\hline Name & $\begin{array}{l}\text { Japan, Total, financial instruments, Transaction as a percentage of } \\
\text { GDP - World (all entities) Total economy (debtor); Japan } \\
\text { Household, Non-profit institutions serving households (creditor), } \\
\text { ESA95 valuation, Neither seasonally or working day adjusted }\end{array}$ \\
\hline Availability & Since January 2001, no data in Oct 01. \\
\hline Source & Bank of Japan \\
\hline
\end{tabular}

BD

\begin{tabular}{|l|l|}
\hline Name & $\begin{array}{l}\text { Japan, Total, financial instruments, Transaction as a percentage of } \\
\text { GDP - Japan Household, Non-profit institutions serving households } \\
\text { (debtor); World (all entities) Total economy (creditor), ESA95 } \\
\text { valuation, Neither seasonally or working day adjusted }\end{array}$ \\
\hline Availability & Since January 2001, no data in Oct 01. \\
\hline Source & Bank of Japan \\
\hline
\end{tabular}

\section{Industry and commodity prices: by type of goods and by industry}

ADDITIONAL NOTES

- Change of a base year from 1995 to 2000 in June 2003

- Methodological notes on the ECB's website:

http://www.ecb.int/stats/prices/hicp/html/index.en.html

SOURCE: Eurostat

BE

\begin{tabular}{|l|l|}
\hline Name & Construction output prices, All residential buildings \\
\hline Units & $\begin{array}{l}\text { Since January 2004: data available as index, } \\
\text { May 2001 to February 2003: data available as annual percentage } \\
\text { changes, } \\
\text { January 2001 to April 2001: data available as index }\end{array}$ \\
\hline $\begin{array}{l}\text { Euro area } \\
\text { concept }\end{array}$ & $\begin{array}{l}\text { Since February 2009: Euro 16 } \\
\text { March 2008 to January 2009: Euro 15 } \\
\text { March 2007 to February 2008: Euro 13 } \\
\text { January 2004 to February 2007: Euro 12 }\end{array}$ \\
\hline
\end{tabular}




\begin{tabular}{|l|l|}
\hline & $\begin{array}{l}\text { May 2001 to February 2003: Euro area changing composition } \\
\text { January 2001 to April 2001: Euro 12 }\end{array}$ \\
\hline Adjustment & Not adjusted \\
\hline
\end{tabular}

\section{GDP: by expenditure components at current prices}

\begin{tabular}{|c|c|}
\hline BF & Total \\
\hline BG & $\begin{array}{l}\text { Domestic demand } \\
\text { Private consumption }\end{array}$ \\
\hline BH & Government consumption \\
\hline BI & Gross fixed capital consumption \\
\hline BJ & Changes in inventories \\
\hline & External balances \\
\hline BK & Exports \\
\hline BL & Imports \\
\hline
\end{tabular}

EURO AREA CONCEPT

Since February 2009: Euro 16

June 2008 to January 2009: Euro 15

June 2007 to May 2008: Euro 13

January 2001 to May 2007: Euro 12

SEASONAL ADJUSTMENT

All data seasonally adjusted

ADDITIONAL NOTES

- Data in millions of ECU/EUR

- During 2005 GDP and national accounts data have been subject to revisions due to the implementation of $(i)$ the introduction of chain-linking of annual and quarterly volume series, (ii) the new partial allocation to final demand of indirectly measured financial intermediation services, and (iii) the benchmark revisions that must be implemented once every five to ten years.

- Methodological notes on the ECB's website: http://www.ecb.int/stats/prices/accounts/html/index.en.html

SOURCE: Eurostat

$\mathrm{BF}$

\begin{tabular}{|l|l|}
\hline Name & Gross domestic product at market price \\
\hline
\end{tabular}

BG

\begin{tabular}{|l|l|}
\hline Name & Final consumption of households and NPISH's (private \\
\hline
\end{tabular} consumption) 
BI

\begin{tabular}{|l|l|}
\hline Name & Gross fixed capital formation \\
\hline
\end{tabular}

BJ

\begin{tabular}{|l|l|l|}
\hline Name & Changes in inventories and acquisitions less disposals of valuables \\
\hline
\end{tabular}

BK

\begin{tabular}{|l|l|}
\hline Name & Exports of goods and services \\
\hline
\end{tabular}

BL

\begin{tabular}{|l|l} 
Name & Imports of goods and services
\end{tabular}

\section{GDP: by expenditure components at constant prices}

$\begin{array}{lc}\text { BM } & \text { Total } \\ & \text { Domestic demand } \\ \text { BN } & \text { Private consumption } \\ \text { BO } & \text { Government consumption } \\ \text { BP } & \text { Gross fixed capital consumption } \\ \text { BQ } & \text { Changes in inventories } \\ & \text { External balances } \\ \text { BR } & \text { Exports } \\ \text { BS } & \text { Imports }\end{array}$

EURO AREA CONCEPT

Since February 2009: Euro 16

June 2008 to January 2009: Euro 15

June 2007 to May 2008: Euro 13

January 2001 to May 2007: Euro 12

SEASONAL ADJUSTMENT

All data seasonally adjusted

ADDITIONAL NOTES

- Data in millions of ECU/EUR at 1995 prices

- Change to chain linking and base year from 1995 to 2000 in December 2005

- During 2005 GDP and national accounts data have been subject to revisions due to the implementation of $(i)$ the introduction of chain-linking of annual and quarterly volume series, (ii) the new partial allocation to final demand of indirectly measured financial intermediation services, and (iii) the benchmark revisions that must be implemented once every five to ten years. 
- Methodological notes on the ECB's website:

http://www.ecb.int/stats/prices/accounts/html/index.en.html

SOURCE: Eurostat

$\mathrm{BM}$

\begin{tabular}{|l|l}
\hline Name & Gross domestic product at constant price
\end{tabular}

$\mathrm{BN}$

\begin{tabular}{|l|l|}
\hline Name & Final consumption of households and NPISH's (private
\end{tabular}

consumption)

$\mathrm{BO}$

\begin{tabular}{|l|l} 
Name & Final consumption of general government
\end{tabular}

BP

\begin{tabular}{|l|l} 
Name & Gross fixed capital formation \\
\hline
\end{tabular}

BQ

\begin{tabular}{|l|l|}
\hline Name & Changes in inventories and acquisitions less disposals of valuables \\
\hline Comments & Discontinued as of June 2007
\end{tabular}

BR

\begin{tabular}{|l|l|} 
Name & Exports of goods and services \\
\hline
\end{tabular}

BS

\begin{tabular}{|l|l|} 
Name & Imports of goods and services \\
\hline
\end{tabular}

\section{Value added: by economic activity at current prices}

Gross value added (basic prices)

$\begin{array}{ll}\text { BT } & \text { Total } \\ \text { BU } & \text { Agriculture, hunting, forestry and fishing activities } \\ \text { BV } & \text { Mining, manufacturing and energy } \\ \text { BW } & \text { Construction } \\ \text { BX } & \text { Trade, repairs, hotels and restaurants, transport and } \\ & \text { communication }\end{array}$

BY Financial, real estate, renting and business activities

BZ Public administration, education, health and other services

CA Intermediate consumption of FISIM

CB Taxes less subsidies on product

EURO AREA CONCEPT

Since February 2009: Euro 16

June 2008 to January 2009: Euro 15 
June 2007 to May 2008: Euro 13

January 2001 to May 2007: Euro 12

SEASONAL ADJUSTMENT

All data seasonally adjusted

ADDITIONAL NOTES

- Data in millions of ECU/EUR

- During 2005 GDP and national accounts data have been subject to revisions due to the implementation of $(i)$ the introduction of chain-linking of annual and quarterly volume series, (ii) the new partial allocation to final demand of indirectly measured financial intermediation services and (iii) the benchmark revisions that must be implemented once every five to ten years.

- Methodological notes on the ECB's website:

http://www.ecb.int/stats/prices/accounts/html/index.en.html

SOURCE: Eurostat

BT

\begin{tabular}{|l|l|}
\hline Name & Gross value added at basic prices: Total
\end{tabular}

BU

\begin{tabular}{|l|l|l}
\hline Name & Gross value added at basic prices: agricultural, hunting, forestry
\end{tabular} and fishing products

BV

\begin{tabular}{|l|l|}
\hline Name & Gross value added at basic prices: total industry
\end{tabular}

BW

\begin{tabular}{l|l} 
Name & Gross value added at basic prices: construction
\end{tabular}

BX

\begin{tabular}{|l|l|}
\hline Name & Gross value added at basic prices: trade, repairs, hotels,
\end{tabular}

\begin{tabular}{|l|l}
\hline Availability & Since April 2001
\end{tabular}

BY

\begin{tabular}{|l|l|}
\hline Name & Gross value added at basic prices: financial intermediation, real
\end{tabular} estate

Availability Since April 2001

BZ

\begin{tabular}{|l|l|}
\hline Name & Gross value added at basic prices: other services \\
\hline Availability & Since April 2001 \\
\hline
\end{tabular}




CA
\begin{tabular}{|l|l|}
\hline Name & Financial intermediation services indirectly measured \\
\hline Availability & Since April 2001 \\
\hline Comments & $\begin{array}{l}\text { In November } 2005 \text { Eurostat introduced a new treatment of FISIM, } \\
\text { allocating financial intermediation services to the different } \\
\text { branches/sectors rather than recording FISIM as the output of a fictious } \\
\text { sector. Hence, from November 2005 FISIM series were set to zero. } \\
\text { The series was discontinued in the database as of June } 2007\end{array}$ \\
\hline
\end{tabular}

CB

\begin{tabular}{|l|l|}
\hline Name & Taxes less subsidies on products \\
\hline Availability & Since April 2001 \\
\hline
\end{tabular}

\section{Value added: by economic activity at constant prices}

$\begin{array}{ll} & \text { Gross value added (basic prices) } \\ \text { CC } & \text { Total } \\ \text { CD } & \text { Agriculture, hunting, forestry and fishing activities } \\ \text { CE } & \text { Mining, manufacturing and energy } \\ \text { CF } & \text { Construction } \\ \text { CG } & \text { Trade, repairs, hotels and restaurants, transport and } \\ & \text { communication } \\ \text { CH } & \text { Financial, real estate, renting and business activities } \\ \text { CI } & \text { Public administration, education, health and other services } \\ \text { CJ } & \text { Intermediate consumption of FISIM } \\ \text { CK } & \text { Taxes less subsidies on product }\end{array}$

EURO AREA CONCEPT

Since February 2009: Euro 16

June 2008 to January 2009: Euro 15

June 2007 to May 2008: Euro 13

January 2001 to May 2007: Euro 12

SEASONAL ADJUSTMENT

All data seasonally adjusted

\section{ADDITIONAL NOTES}

- Data in millions of ECU at 1995 prices

- Chain-linking introduced in June 2007

- During 2005 GDP and national accounts data have been subject to revisions due to the implementation of $(i)$ the introduction of chain-linking of annual and quarterly volume series, (ii) the new partial allocation to final demand of indirectly measured financial intermediation and (iii) the benchmark revisions that must be implemented once every five to ten years.

- Methodological notes on the ECB's website: http://www.ecb.int/stats/prices/accounts/html/index.en.html 
$\mathrm{CC}$

\begin{tabular}{|l|l} 
Name & Gross value added at basic prices: Total
\end{tabular}

CD

\begin{tabular}{|l|l|l|l}
\hline Name & Gross value added at basic prices: agricultural, hunting, forestry
\end{tabular} and fishing products

CE

\begin{tabular}{|l|l|}
\hline Name & Gross value added at basic prices: total industry \\
\hline
\end{tabular}

$\mathrm{CF}$

\begin{tabular}{|l|l}
\hline Name & Gross value added at basic prices: construction \\
\hline
\end{tabular}

CG

\begin{tabular}{|l|l}
\hline Name & Gross value added at basic prices: trade, repairs, hotels,
\end{tabular} restaurants, transport and communication

\section{$\mathrm{CH}$}

Name

Gross value added at basic prices: financial intermediation, real estate

CI

\begin{tabular}{|l|l}
\hline Name & Gross value added at basic prices: other services
\end{tabular}

CJ

Name

Financial intermediation services indirectly measured

Comments

In November 2005 Eurostat introduced a new treatment of FISIM, allocating financial intermediation services to the different branches/sectors rather than recording FISIM as the output of a fictious sector. Hence, from November 2005 FISIM series were set to zero.

The series discontinued in the database as of June 2007.

CK

Name

Taxes less subsidies on products

Confidence indicators: economic, manufacturing, consumer, construction, retail trade, services

ADDITIONAL NOTES

- See the documentation of monthly variables

SOURCE: European Commission: DG ECFIN 
CL

\begin{tabular}{|l|l|}
\hline Name & Industry Survey: Current level of capacity utilization \\
\hline Units & Percentage balances \\
\hline $\begin{array}{l}\text { Euro area } \\
\text { concept }\end{array}$ & $\begin{array}{l}\text { Since February 2009: Euro 16 } \\
\text { February 2008 to January 2009: Euro 15 } \\
\text { February 2007 to January 2008: Euro 13 } \\
\text { February 2006 to January 2007: Euro 12 }\end{array}$ \\
\hline Availability & Since February 2006 \\
\hline Comments & $\begin{array}{l}\text { Owing to changes in the questionnaire used for the French survey, euro } \\
\text { area results from January 2004 onwards are not fully comparable with } \\
\text { previous results. }\end{array}$ \\
\hline Source & European Commission: DG ECFIN \\
\hline
\end{tabular}




\section{Overview of annual indicators}

\section{Government finance: deficit/surplus and government consumption}

$\begin{array}{lc} & \text { Deficit (-)/surplus (+) } \\ \text { B } & \text { Total } \\ \text { C } & \text { Central government } \\ \text { D } & \text { State government } \\ \text { E } & \text { Local government } \\ \text { F } & \text { Social security funds } \\ \text { G } & \text { Primary deficit (-)/ surplus (+) } \\ & \text { Government consumption } \\ \text { H } & \text { Total } \\ \text { I } & \text { Compensation of employees } \\ \text { J } & \text { Intermediate consumption } \\ \text { K } & \text { Transfers in kind via market producers } \\ \text { L } & \text { Consumption of fixed capital } \\ \text { M } & \text { Sales (minus) } \\ \text { N } & \text { Collective consumption } \\ \text { O } & \text { Individual consumption }\end{array}$

EURO AREA CONCEPT

Since May 2009: Euro 16

May 2008 to April 2009: Euro 15

May 2007 to April 2008: Euro 13

January 2001 - March 2007: Euro 12

SEASONAL ADJUSTMENT

No adjustment

METHODOLOGICAL NOTES

- Data expressed as percentage of GDP

- Methodological notes on the ECB's website:

http://www.ecb.int/stats/acc/gov/html/index.en.html

SOURCE: ECB

\section{$\mathrm{B}$}

\begin{tabular}{|l|l|}
\hline Name & $\begin{array}{l}\text { Deficit/surplus without UMTS proceeds - All sectors/ unspecified/ } \\
\text { not applicable (ESA95)-NCBs - General government (ESA95)- } \\
\text { NCBs - Non-financial flows current prices }\end{array}$ \\
\hline
\end{tabular}

$\mathrm{C}$

\begin{tabular}{|l|l|l|}
\hline Name & Deficit/surplus without UMTS proceeds - All sectors/ unspecified/
\end{tabular} not applicable (ESA95)-NCBs - Central government (ESA95)-NCBs - Non-financial flows current prices 
$\mathrm{D}$

\begin{tabular}{|l|l|}
\hline Name & $\begin{array}{l}\text { Deficit or surplus - All sectors/ unspecified/ not applicable (ESA95)- } \\
\text { NCBs - State government (ESA95)-NCBs - Non-financial flows } \\
\text { current prices }\end{array}$ \\
\hline
\end{tabular}

$\mathrm{E}$

\begin{tabular}{|l|l}
\hline Name & Deficit or surplus - All sectors/ unspecified/ not applicable
\end{tabular} (ESA95)-NCBs - Local government (ESA95)-NCBs - Non-financial flows current prices

$\mathrm{F}$

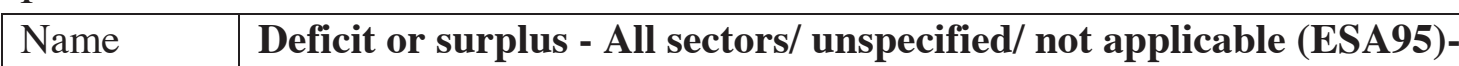
NCBs - Social security funds (ESA95)-NCBs - Non-financial flows current prices

G

\begin{tabular}{|l|l|}
\hline Name & Primary deficit/surplus without UMTS proceeds - All sectors/
\end{tabular} unspecified/ not applicable (ESA95)-NCBs - General government (ESA95)-NCBs - Non-financial flows current prices

$\mathrm{H}$

\begin{tabular}{|l|l|}
\hline Name & $\begin{array}{l}\text { Final consumption expenditure (P3, ESA 95) - All sectors/ } \\
\text { unspecified/ not applicable (ESA95)-NCBs - General government } \\
\text { (ESA95)-NCBs - Non-financial flows current prices }\end{array}$ \\
\hline
\end{tabular}

I

\begin{tabular}{|l|l|}
\hline Name & $\begin{array}{l}\text { Compensation of employees - All sectors without GG } \\
\text { (consolidation) (ESA95)-NCBs - General government (ESA95)- } \\
\text { NCBs - Non-financial flows current prices }\end{array}$ \\
\hline
\end{tabular}

$\mathrm{J}$

\begin{tabular}{|l|l|}
\hline Name & $\begin{array}{l}\text { Intermediate consumption - All sectors/ unspecified/ not applicable } \\
\text { (ESA95)-NCBs - General government (ESA95)-NCBs - Non- } \\
\text { financial flows current prices }\end{array}$ \\
\hline
\end{tabular}

$\mathrm{K}$

\begin{tabular}{|l|l}
\hline Name & Social transfers in kind via non-government producers -
\end{tabular}

Households (ESA95)-NCBs - General government (ESA95)-NCBs -

Non-financial flows current prices

$\mathrm{L}$

\begin{tabular}{|l|l|}
\hline Name & $\begin{array}{l}\text { Consumption of fixed capital - All sectors/ unspecified/ not } \\
\text { applicable (ESA95)-NCBs - General government (ESA95)-NCBs - } \\
\text { Non-financial flows current prices }\end{array}$ \\
\hline
\end{tabular}

M

\begin{tabular}{|l|l|}
\hline Name & $\begin{array}{l}\text { Sales - General government (ESA95)-NCBs - All sectors without } \\
\text { EU institutions (ESA95)-NCBs - Non-financial flows current prices }\end{array}$ \\
\hline
\end{tabular} 
$\mathrm{N}$

\begin{tabular}{|l|l} 
Name & Collective consumption expenditure (P32, ESA 95) - All sectors/
\end{tabular} unspecified/ not applicable (ESA95)-NCBs - General government (ESA95)-NCBs - Non-financial flows current prices

$\mathrm{O}$

\begin{tabular}{|l|l|}
\hline Name & $\begin{array}{l}\text { Euro } 12 \text { - Individual consumption expenditure (P31, ESA 95) - All } \\
\text { sectors/ unspecified/ not applicable (ESA95)-NCBs - General } \\
\text { government (ESA95)-NCBs - Non-financial flows current prices - } \\
\text { Percentage points, series(t)/GDP(t) - Neither seasonally or working day } \\
\text { adjusted }\end{array}$ \\
\hline
\end{tabular}

\section{US and Japan: main economic and financial indicators}

SEASONAL ADJUSTMENT

Neither seasonally or working day adjusted

METHODOLOGICAL NOTES

- Data expressed as a percentage of GDP

SOURCE: Bank of Japan

\section{$\mathrm{P}$}

\begin{tabular}{|l|l}
\hline Name & Japan - Deficit or surplus - All sectors/ unspecified/ not applicable
\end{tabular} (ESA95)-NCBs - General government (ESA95)-NCBs - Nonfinancial flows current prices

Q

\begin{tabular}{|l|l|}
\hline Name & $\begin{array}{l}\text { Japan - Maastricht assets/liabilities - General government (ESA95)- } \\
\text { NCBs - All sectors without GG (consolidation) (ESA95)-NCBs - } \\
\text { Financial stocks - ESA 79 / Maastricht valuation }\end{array}$ \\
\hline Availability & Since October 2002 \\
\hline
\end{tabular}

$\mathrm{R}$

\begin{tabular}{|l|l|}
\hline Name & Japan, Gross capital formation, Transaction as a percentage of
\end{tabular} GDP - World not allocated (geographically) Not applicable (debtor); Japan Non-financial corporations (creditor), ESA95 valuation,

\section{$\mathrm{S}$}

\begin{tabular}{|l|l|}
\hline Name & Japan, Gross saving, Transaction as a percentage of GDP - Japan
\end{tabular} Non-financial corporations (debtor); World not allocated (geographically) Not applicable (creditor), ESA95 valuation, 


\begin{tabular}{|l|l|} 
T \\
\begin{tabular}{|l|l|} 
Name & Japan, Gross capital formation, Transaction as a percentage of \\
GDP - World not allocated (geographically) Not applicable \\
(debtor); Japan Household, Non-profit institutions serving \\
households (creditor), ESA95 valuation
\end{tabular} \\
\hline
\end{tabular}

$\mathrm{U}$

\begin{tabular}{|l|l|}
\hline Name & Japan, Gross saving, Transaction as a percentage of GDP - Japan
\end{tabular}

Household, Non-profit institutions serving households (debtor);

World not allocated (geographically) Not applicable (creditor),

ESA95 valuation 
Annex 4: Additional detailed revision statistics

T1.1 HICP breakdown

T1.2 Industrial producer prices

T1.3 Hourly labour costs

T1.4 Unit labour costs

T1.5 GDP deflators

T2.1 GDP breakdown

T2.2 Value added breakdown

T2.3 Industrial production

T2.4 Retail sales

T2.5 Business and Consumer Surveys 
TI HICP, other prices and costs

(annual percentage changes)

1. Harmonised Index of Consumer Prices

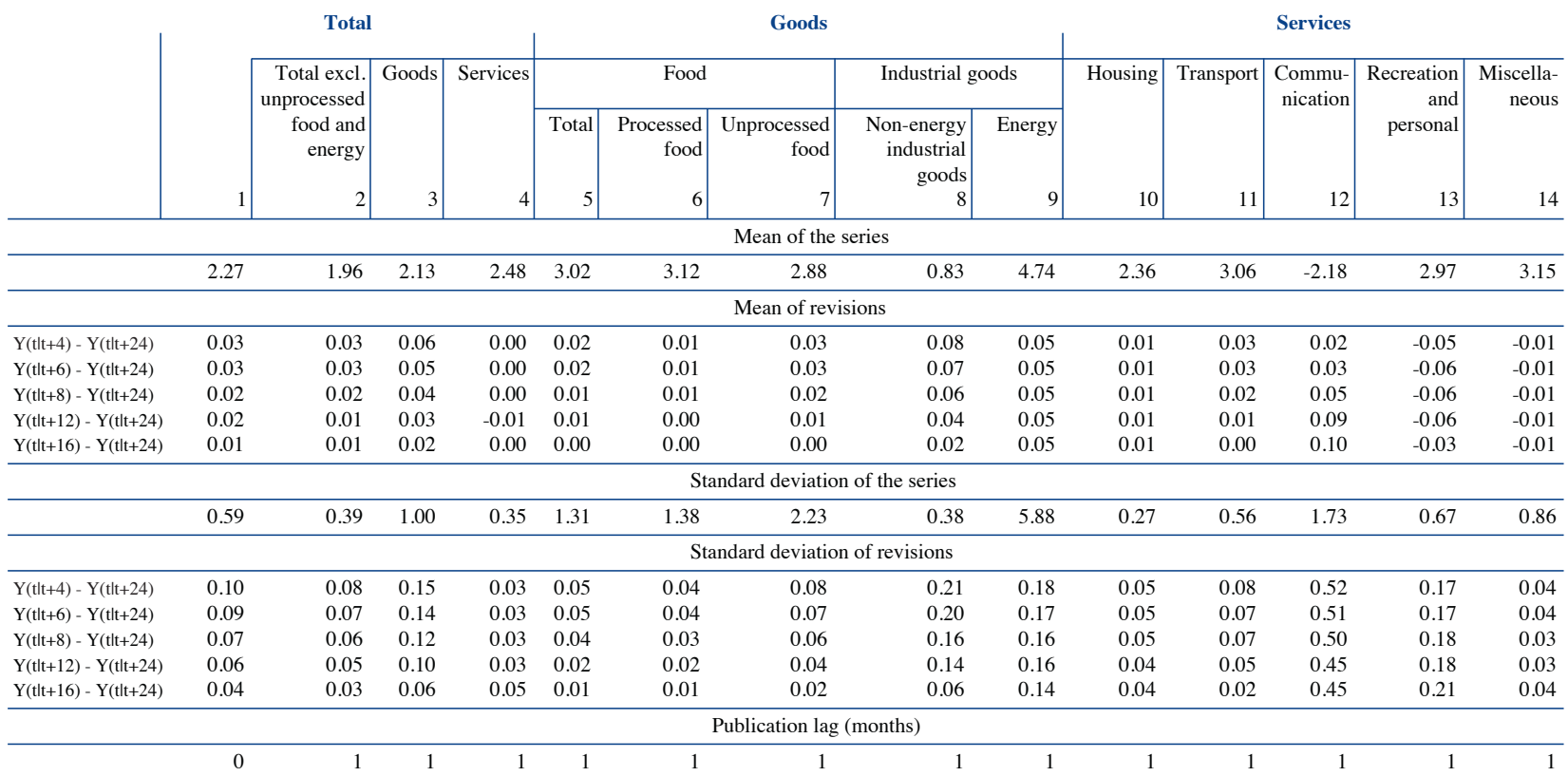

Sources: Eurostat and ECB calculations based on Eurostat data 


\section{Industrial producer prices excluding construction}

\begin{tabular}{|c|c|c|c|c|c|c|c|c|c|}
\hline & \multicolumn{2}{|c|}{ Total } & \multicolumn{6}{|c|}{ Industry excluding construction and energy } & \multirow{3}{*}{$\begin{array}{r}\text { Energy } \\
9 \\
9\end{array}$} \\
\hline & \multirow[b]{2}{*}{1} & \multirow{2}{*}{$\begin{array}{r}\begin{array}{r}\text { Manu- } \\
\text { facturing }\end{array} \\
2\end{array}$} & \multirow{2}{*}{$\begin{array}{r}\text { Total } \\
3 \\
\end{array}$} & \multirow{2}{*}{$\begin{array}{r}\text { Intermediate } \\
\text { goods } \\
4 \\
4\end{array}$} & \multirow{2}{*}{ 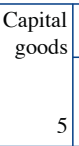 } & \multicolumn{3}{|c|}{ Consumer goods } & \\
\hline & & & & & & \begin{tabular}{r|} 
Total \\
6
\end{tabular} & $\begin{array}{r}\text { Durable } \\
7 \\
\end{array}$ & $\begin{array}{r}\text { Non-durable } \\
8\end{array}$ & \\
\hline \multicolumn{10}{|c|}{ Mean of the series } \\
\hline & 2.79 & 2.47 & 1.94 & 2.55 & 1.20 & 1.83 & 1.65 & 1.78 & 6.27 \\
\hline \multicolumn{10}{|c|}{ Mean of revisions } \\
\hline $\mathrm{Y}(\mathrm{t} \mid t+4)-\mathrm{Y}(\mathrm{t} \mid \mathrm{t}+24)$ & 0.02 & -0.02 & 0.04 & 0.12 & 0.04 & 0.01 & 0.00 & 0.04 & -0.04 \\
\hline $\mathrm{Y}(\mathrm{tt}+6)-\mathrm{Y}(\mathrm{tt}+24)$ & 0.03 & -0.02 & 0.05 & 0.06 & 0.04 & 0.02 & 0.01 & 0.04 & -0.03 \\
\hline $\mathrm{Y}(\mathrm{tlt}+8)-\mathrm{Y}(\mathrm{tlt}+24)$ & 0.03 & -0.02 & 0.05 & 0.01 & 0.03 & 0.03 & 0.01 & 0.05 & -0.03 \\
\hline $\mathrm{Y}(\mathrm{t} \mid \mathrm{t}+12)-\mathrm{Y}(\mathrm{tlt}+24)$ & 0.03 & -0.01 & 0.03 & 0.01 & 0.01 & 0.04 & 0.03 & 0.06 & 0.02 \\
\hline $\mathrm{Y}(\mathrm{t} t \mathrm{t}+16)-\mathrm{Y}(\mathrm{tt}+24)$ & 0.03 & -0.01 & 0.02 & 0.01 & 0.00 & 0.04 & 0.03 & 0.05 & 0.05 \\
\hline \multicolumn{10}{|c|}{ Standard deviation of the series } \\
\hline & 2.46 & 1.91 & 1.35 & 2.51 & 0.75 & 1.26 & 0.68 & 1.39 & 8.02 \\
\hline \multicolumn{10}{|c|}{ Standard deviation of revisions } \\
\hline$Y(t \mid t+4)-Y(t \mid t+24)$ & 0.13 & 0.14 & 0.08 & 0.54 & 0.14 & 0.16 & 0.17 & 0.19 & 0.54 \\
\hline $\mathrm{Y}(\mathrm{t} t \mathrm{t}+6)-\mathrm{Y}(\mathrm{t} \mathrm{t}+24)$ & 0.12 & 0.14 & 0.08 & 0.38 & 0.14 & 0.14 & 0.16 & 0.18 & 0.51 \\
\hline $\mathrm{Y}(\mathrm{tlt}+8)-\mathrm{Y}(\mathrm{tlt}+24)$ & 0.11 & 0.14 & 0.08 & 0.10 & 0.13 & 0.15 & 0.16 & 0.17 & 0.48 \\
\hline $\mathrm{Y}(\mathrm{t} \mid \mathrm{t}+12)-\mathrm{Y}(\mathrm{t} \mathrm{t}+24)$ & 0.10 & 0.10 & 0.07 & 0.09 & 0.12 & 0.13 & 0.15 & 0.16 & 0.42 \\
\hline $\mathrm{Y}(\mathrm{tlt}+16)-\mathrm{Y}(\mathrm{tt}+24)$ & 0.08 & 0.07 & 0.06 & 0.09 & 0.11 & 0.10 & 0.14 & 0.14 & 0.36 \\
\hline \multicolumn{10}{|c|}{ Publication lag (months) } \\
\hline & 1 & 1 & 1 & 1 & 1 & 1 & 1 & 1 & 1 \\
\hline
\end{tabular}

\section{Hourly labour costs}

\begin{tabular}{|c|c|c|c|c|c|c|}
\hline & \multirow{2}{*}{$\begin{array}{r}\text { Total } \\
\\
\\
1 \\
\end{array}$} & \multicolumn{2}{|c|}{ By component } & \multicolumn{3}{|c|}{ By selected economic activity } \\
\hline & & $\begin{array}{r}\begin{array}{r}\text { Wages and } \\
\text { salaries }\end{array} \\
2\end{array}$ & $\begin{array}{r}\begin{array}{r}\text { Employers' social } \\
\text { contributions }\end{array} \\
3 \\
\end{array}$ & $\begin{array}{r}\text { Mining, } \\
\text { manufacturing } \\
\text { and energy } \\
4\end{array}$ & Construction & Services \\
\hline \multicolumn{7}{|c|}{ Mean of the series } \\
\hline & 3.05 & 3.05 & 3.01 & 3.20 & 3.24 & 3.18 \\
\hline \multicolumn{7}{|c|}{ Mean of revisions } \\
\hline $\mathrm{Y}(\mathrm{tlt}+4)-\mathrm{Y}(\mathrm{t} \mid \mathrm{t}+24)$ & -0.14 & -0.15 & -0.08 & -0.37 & -0.21 & -0.26 \\
\hline$Y(t \mid t+6)-Y(t \mid t+24)$ & -0.13 & -0.15 & -0.07 & -0.34 & -0.19 & -0.28 \\
\hline $\mathrm{Y}(\mathrm{t} \mid \mathrm{t}+8)-\mathrm{Y}(\mathrm{t} \mid \mathrm{t}+24)$ & -0.09 & -0.11 & -0.06 & -0.25 & -0.15 & -0.24 \\
\hline $\mathrm{Y}(\mathrm{tlt}+12)-\mathrm{Y}(\mathrm{tlt}+24)$ & -0.06 & -0.07 & -0.03 & -0.20 & -0.07 & -0.20 \\
\hline $\mathrm{Y}(\mathrm{tlt}+16)-\mathrm{Y}(\mathrm{tlt}+24)$ & 0.01 & -0.02 & 0.01 & -0.12 & -0.01 & -0.07 \\
\hline \multicolumn{7}{|c|}{ Standard deviation of the series } \\
\hline & 0.57 & 0.60 & 0.59 & 0.94 & 0.71 & 1.03 \\
\hline \multicolumn{7}{|c|}{ Standard deviation of revisions } \\
\hline $\mathrm{Y(t|t+4)}-\mathrm{Y}(\mathrm{tlt}+24)$ & 0.27 & 0.28 & 0.33 & 0.77 & 0.44 & 0.57 \\
\hline $\mathrm{Y}(\mathrm{tt}+6)-\mathrm{Y}(\mathrm{tlt}+24)$ & 0.26 & 0.26 & 0.32 & 0.71 & 0.43 & 0.58 \\
\hline $\mathrm{Y}(\mathrm{t} \mid \mathrm{t}+8)-\mathrm{Y}(\mathrm{tlt}+24)$ & 0.26 & 0.27 & 0.29 & 0.67 & 0.40 & 0.58 \\
\hline $\mathrm{Y}(\mathrm{t} t+12)-\mathrm{Y}(\mathrm{t} t \mathrm{t}+24)$ & 0.21 & 0.24 & 0.22 & 0.56 & 0.37 & 0.51 \\
\hline $\mathrm{Y}(\mathrm{t} \mid \mathrm{t}+16)-\mathrm{Y}(\mathrm{t} \mathrm{t}+24)$ & 0.20 & 0.22 & 0.22 & 0.47 & 0.27 & 0.44 \\
\hline \multicolumn{7}{|c|}{ Publication lag (months) } \\
\hline & 3 & 3 & 3 & 3 & 3 & 3 \\
\hline
\end{tabular}

Sources: Eurostat and ECB calculations based on Eurostat data. 
TI HICP, other prices and costs

(annual percentage changes)

4. Unit labour costs

(seasonally adjusted)

\begin{tabular}{|c|c|c|c|c|c|c|c|}
\hline & \multirow{2}{*}{$\begin{array}{r}\text { Total } \\
\\
1 \\
1\end{array}$} & \multicolumn{6}{|c|}{ By economic activity } \\
\hline & & $\begin{array}{r}\text { Agriculture, hunting, } \\
\text { forestry and fishing }\end{array}$ & $\begin{array}{r}\text { Mining, } \\
\text { manufacturing } \\
\text { and energy } \\
3\end{array}$ & Construction & $\begin{array}{r}\text { Trade, repairs, hotels and } \\
\text { restaurants, transport and } \\
\text { communication } \\
5\end{array}$ & $\begin{array}{r}\text { Financial, real estate, } \\
\text { renting and business } \\
\text { services } \\
6\end{array}$ & $\begin{array}{r}\text { Public administration, } \\
\text { education, health } \\
\text { and other services } \\
7\end{array}$ \\
\hline \multicolumn{8}{|c|}{ Mean of the series } \\
\hline & 1.80 & 1.74 & 0.34 & 3.07 & 1.27 & 2.80 & 2.66 \\
\hline \multicolumn{8}{|c|}{ Mean of revisions } \\
\hline $\mathrm{Y}(\mathrm{tt}+4)-\mathrm{Y}(\mathrm{tt}+24)$ & -0.09 & 1.76 & -0.80 & -0.20 & 0.16 & 0.19 & -0.52 \\
\hline$Y(t \mathrm{tt}+6)-\mathrm{Y}(\mathrm{tt}+24)$ & -0.05 & 0.55 & -0.14 & 0.18 & -0.09 & 0.21 & -0.46 \\
\hline $\mathrm{Y}(\mathrm{tlt}+8)-\mathrm{Y}(\mathrm{tlt}+24)$ & -0.01 & 0.54 & -0.14 & 0.22 & -0.12 & 0.21 & -0.46 \\
\hline $\mathrm{Y}(\mathrm{tlt}+12)-\mathrm{Y}(\mathrm{tlt}+24)$ & 0.00 & 1.20 & 0.07 & 0.17 & -0.06 & 0.04 & -0.35 \\
\hline $\mathrm{Y}(\mathrm{tlt}+16)-\mathrm{Y}(\mathrm{tlt}+24)$ & -0.02 & 1.02 & 0.05 & 0.05 & -0.03 & 0.03 & -0.23 \\
\hline \multicolumn{8}{|c|}{ Standard deviation of the series } \\
\hline & 0.93 & 5.85 & 2.17 & 1.08 & 1.33 & 0.91 & 0.84 \\
\hline \multicolumn{8}{|c|}{ Standard deviation of revisions } \\
\hline$Y(t \mathrm{tt}+4)-\mathrm{Y}(\mathrm{tt}+24)$ & 0.30 & 4.79 & 1.02 & 1.29 & 0.78 & 0.51 & 0.68 \\
\hline $\mathrm{Y}(\mathrm{t} t \mathrm{t}+6)-\mathrm{Y}(\mathrm{t} \mid \mathrm{t}+24)$ & 0.37 & 3.37 & 0.71 & 1.17 & 0.68 & 0.97 & 0.49 \\
\hline $\mathrm{Y}(\mathrm{tt}+8)-\mathrm{Y}(\mathrm{ttt}+24)$ & 0.33 & 3.07 & 0.75 & 1.14 & 0.60 & 0.82 & 0.51 \\
\hline $\mathrm{Y}(\mathrm{tlt}+12)-\mathrm{Y}(\mathrm{tlt}+24)$ & 0.20 & 2.92 & 0.64 & 1.01 & 0.45 & 0.75 & 0.50 \\
\hline $\mathrm{Y}(\mathrm{tlt}+16)-\mathrm{Y}(\mathrm{tlt}+24)$ & 0.15 & 2.19 & 0.53 & 1.05 & 0.43 & 0.74 & 0.57 \\
\hline \multicolumn{8}{|c|}{ Publication lag (months) } \\
\hline
\end{tabular}

\section{Gross domestic product deflators}

\begin{tabular}{|c|c|c|c|c|c|c|c|}
\hline & \multirow{2}{*}{$\begin{array}{r}\text { Total } \\
\\
1 \\
1\end{array}$} & \multicolumn{4}{|c|}{ Domestic demand } & \multirow{2}{*}{$\begin{array}{r}\text { Exports } \\
\\
6\end{array}$} & \multirow{2}{*}{$\begin{array}{r}\text { Imports } \\
7\end{array}$} \\
\hline & & $\begin{array}{r}\text { Total } \\
\\
2 \\
\end{array}$ & $\begin{array}{r}\text { Private } \\
\text { consumption } \\
3 \\
\end{array}$ & 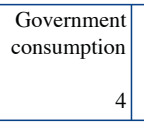 & $\begin{array}{r}\text { Gross fixed capital } \\
\text { formation } \\
5 \\
\end{array}$ & & \\
\hline \multicolumn{8}{|c|}{ Mean of the series } \\
\hline & 2.16 & 2.31 & 2.22 & 2.40 & 2.12 & 1.31 & 1.59 \\
\hline \multicolumn{8}{|c|}{ Mean of revisions } \\
\hline $\mathrm{Y}(\mathrm{t} t+4)-\mathrm{Y}(\mathrm{t} t \mathrm{t}+24)$ & -0.08 & -0.07 & -0.12 & -0.45 & 0.12 & 0.03 & 0.07 \\
\hline $\mathrm{Y}(\mathrm{tlt}+6)-\mathrm{Y}(\mathrm{t} t+24)$ & -0.12 & -0.11 & -0.10 & -0.49 & 0.11 & 0.11 & 0.17 \\
\hline $\mathrm{Y}(\mathrm{tlt}+8)-\mathrm{Y}(\mathrm{t} \mid \mathrm{t}+24)$ & -0.11 & -0.06 & -0.12 & -0.47 & 0.14 & 0.05 & 0.19 \\
\hline $\mathrm{Y}(\mathrm{t} t \mathrm{t}+12)-\mathrm{Y}(\mathrm{tlt}+24)$ & -0.11 & -0.10 & -0.01 & -0.38 & 0.04 & 0.09 & 0.10 \\
\hline$Y(t \mid t+16)-Y(t \mid t+24)$ & -0.08 & -0.07 & 0.02 & -0.26 & 0.01 & 0.02 & 0.04 \\
\hline \multicolumn{8}{|c|}{ Standard deviation of the series } \\
\hline & 0.32 & 0.41 & 0.53 & 0.68 & 0.76 & 1.87 & 3.24 \\
\hline \multicolumn{8}{|c|}{ Standard deviation of revisions } \\
\hline $\mathrm{Y}(\mathrm{tlt}+4)-\mathrm{Y}(\mathrm{t} t \mathrm{t}+24)$ & 0.22 & 0.17 & 0.16 & 0.63 & 0.29 & 0.57 & 0.55 \\
\hline $\mathrm{Y}(\mathrm{tlt}+6)-\mathrm{Y}(\mathrm{tt}+24)$ & 0.14 & 0.21 & 0.16 & 0.44 & 0.40 & 0.38 & 0.41 \\
\hline $\mathrm{Y}(\mathrm{tlt}+8)-\mathrm{Y}(\mathrm{t} t \mathrm{t}+24)$ & 0.14 & 0.16 & 0.16 & 0.41 & 0.26 & 0.30 & 0.29 \\
\hline $\mathrm{Y}(\mathrm{t} t \mathrm{t}+12)-\mathrm{Y}(\mathrm{tlt}+24)$ & 0.12 & 0.20 & 0.15 & 0.45 & 0.32 & 0.42 & 0.23 \\
\hline $\mathrm{Y}(\mathrm{tlt}+16)-\mathrm{Y}(\mathrm{tlt}+24)$ & 0.13 & 0.16 & 0.17 & 0.29 & 0.24 & 0.29 & 0.21 \\
\hline \multicolumn{8}{|c|}{ Publication lag (months) } \\
\hline & 2 & 2 & 2 & 2 & 2 & 2 & 2 \\
\hline
\end{tabular}

Sources: ECB calculations based on Eurostat data. 


\section{GDP and expenditure components}

(seasonally adjusted)

GDP

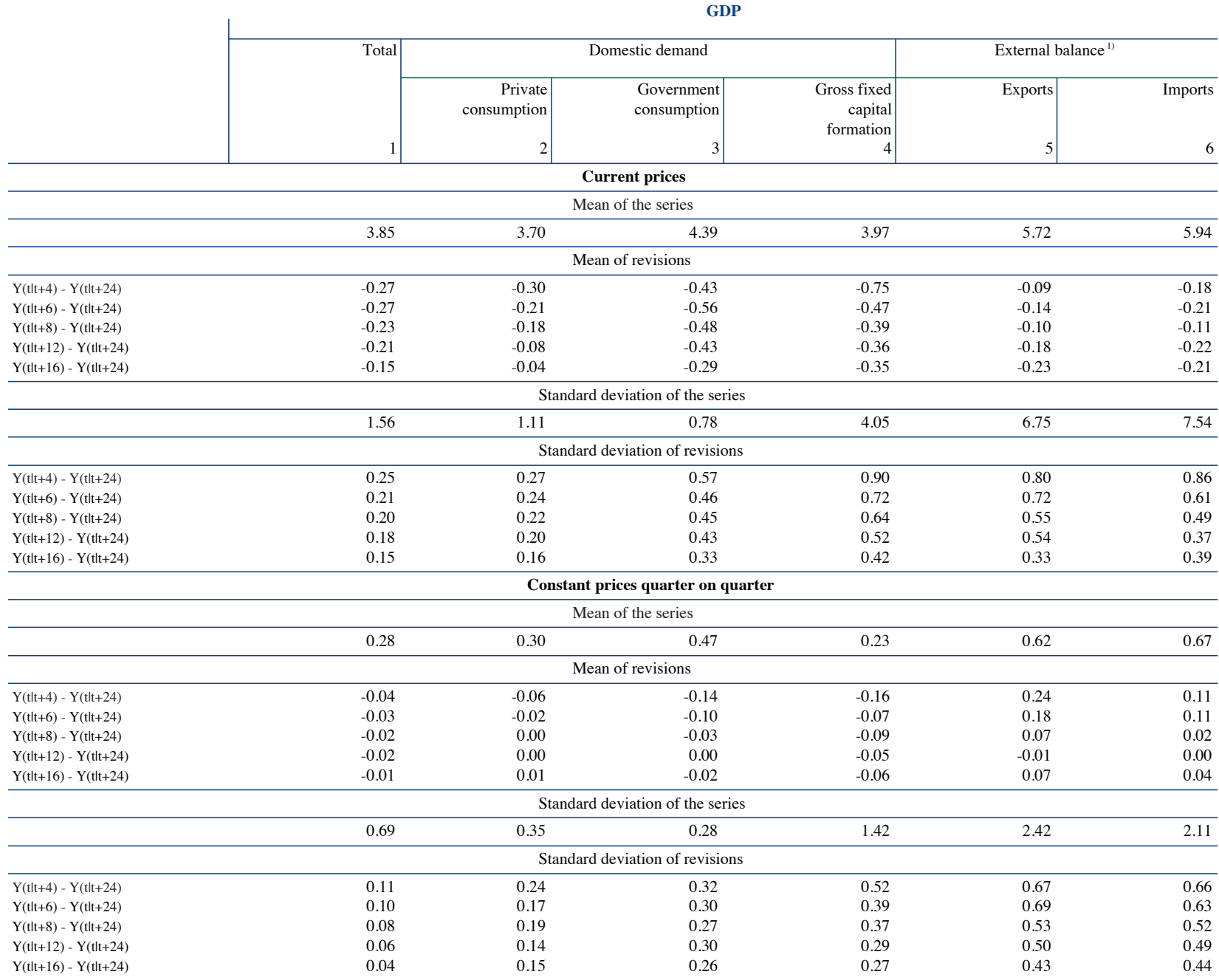

Sources: Eurostat and ECB calculations. 
1. GDP and expenditure components (cont'd)

(seasonally adjusted)

GDP

\begin{tabular}{|c|c|c|c|c|c|c|}
\hline \multicolumn{7}{|c|}{ GDP } \\
\hline & \multirow{2}{*}{$\begin{array}{r}\text { Total } \\
1 \\
1\end{array}$} & \multicolumn{3}{|c|}{ Domestic demand } & \multicolumn{2}{|c|}{ External balance } \\
\hline & & 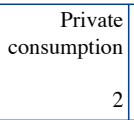 & 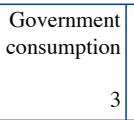 & $\begin{array}{r}\text { Gross fixed } \\
\text { capital } \\
\text { formation } \\
4\end{array}$ & Exports & Imports \\
\hline \multicolumn{7}{|c|}{ Constant prices year on year } \\
\hline \multicolumn{7}{|c|}{ Mean of the series } \\
\hline & 1.65 & 1.44 & 1.94 & 1.79 & 4.26 & 4.16 \\
\hline \multicolumn{7}{|c|}{ Mean of revisions } \\
\hline $\mathrm{Y}(\mathrm{tlt}+4)-\mathrm{Y}(\mathrm{t} \mid \mathrm{t}+24)$ & -0.15 & -0.13 & -0.16 & -0.67 & -0.04 & -0.27 \\
\hline $\mathrm{Y}(\mathrm{tt}+6)-\mathrm{Y}(\mathrm{tt}+24)$ & -0.14 & -0.10 & -0.06 & -0.57 & -0.25 & -0.38 \\
\hline $\mathrm{Y}(\mathrm{tt}+\mathrm{t})-\mathrm{Y}(\mathrm{ttl}+24)$ & -0.12 & -0.06 & 0.00 & -0.52 & -0.15 & -0.30 \\
\hline $\mathrm{Y}(\mathrm{ttl}+12)-\mathrm{Y}(\mathrm{tt}+24)$ & -0.10 & -0.06 & -0.05 & -0.39 & -0.26 & -0.31 \\
\hline $\mathrm{Y}(\mathrm{tt}+16)-\mathrm{Y}(\mathrm{tt}+24)$ & -0.07 & -0.06 & -0.02 & -0.34 & -0.23 & -0.24 \\
\hline \multicolumn{7}{|c|}{ Standard deviation of the series } \\
\hline & 1.57 & 0.84 & 0.38 & 3.44 & 5.21 & 4.70 \\
\hline \multicolumn{7}{|c|}{ Standard deviation of revisions } \\
\hline $\mathrm{Y}(\mathrm{tlt}+4)-\mathrm{Y}(\mathrm{t} t \mathrm{t}+24)$ & 0.19 & 0.28 & 0.66 & 0.90 & 0.73 & 0.78 \\
\hline $\mathrm{Y}(\mathrm{tt}+6)-\mathrm{Y}(\mathrm{tt}+24)$ & 0.17 & 0.23 & 0.56 & 0.74 & 0.72 & 0.64 \\
\hline $\mathrm{Y}(\mathrm{tlt}+8)-\mathrm{Y}(\mathrm{tlt}+24)$ & 0.14 & 0.24 & 0.56 & 0.68 & 0.51 & 0.50 \\
\hline $\mathrm{Y}(\mathrm{tlt}+12)-\mathrm{Y}(\mathrm{tlt}+24)$ & 0.12 & 0.23 & 0.56 & 0.51 & 0.42 & 0.41 \\
\hline $\mathrm{Y}(\mathrm{tt}+16)-\mathrm{Y}(\mathrm{tt}+24)$ & 0.09 & 0.25 & 0.45 & 0.41 & 0.39 & 0.36 \\
\hline \multicolumn{7}{|c|}{ Publication lag (months) } \\
\hline & 2 & 2 & 2 & 2 & 2 & 2 \\
\hline
\end{tabular}

Sources: Eurostat and ECB calculations. 


\section{Value added by economic activity}

(seasonally adjusted)

\begin{tabular}{|c|c|c|c|c|c|c|c|c|}
\hline & \multicolumn{7}{|c|}{ Gross value added (basic prices) } & \multirow[b]{2}{*}{$\begin{array}{r}\text { Taxes less } \\
\text { subsidies on } \\
\text { products } \\
8 \\
8\end{array}$} \\
\hline & Total & $\begin{array}{r}\text { Agriculture, } \\
\text { hunting, } \\
\text { forestry } \\
\text { and fishing } \\
\text { activities } \\
2\end{array}$ & $\begin{array}{r}\text { Mining, } \\
\text { manufacturing } \\
\text { and energy }\end{array}$ & Construction & $\begin{array}{r}\text { Trade, repairs, } \\
\text { hotels and } \\
\text { restaurants, } \\
\text { transport and } \\
\text { communication } \\
5\end{array}$ & $\begin{array}{r}\text { Financial, real } \\
\text { estate, renting } \\
\text { and business } \\
\text { activities }\end{array}$ & $\begin{array}{r}\text { Public } \\
\text { administration, } \\
\text { education, } \\
\text { health and } \\
\text { other services } \\
7\end{array}$ & \\
\hline \multicolumn{9}{|c|}{ Current prices } \\
\hline \multicolumn{9}{|c|}{ Mean of the series } \\
\hline & 3.90 & -0.28 & 2.41 & 5.47 & 3.73 & 4.97 & 4.18 & 3.46 \\
\hline \multicolumn{9}{|c|}{ Mean of revisions } \\
\hline $\mathrm{Y}(\mathrm{tlt}+4)-\mathrm{Y}(\mathrm{tlt}+24)$ & -0.25 & 2.68 & 0.04 & -0.39 & -0.33 & -0.22 & -0.70 & -0.64 \\
\hline $\mathrm{Y}(\mathrm{tlt}+6)-\mathrm{Y}(\mathrm{t} t \mathrm{t}+24)$ & -0.24 & 2.00 & -0.11 & -0.37 & -0.20 & -0.25 & -0.54 & -0.82 \\
\hline $\mathrm{Y}(\mathrm{tlt}+8)-\mathrm{Y}(\mathrm{tlt}+24)$ & -0.21 & 1.81 & -0.08 & -0.35 & -0.18 & -0.24 & -0.49 & -0.59 \\
\hline$Y(t \mid t+12)-Y(t \mid t+24)$ & -0.16 & 1.37 & -0.16 & -0.39 & -0.08 & -0.15 & -0.34 & -0.67 \\
\hline $\mathrm{Y}(\mathrm{tlt}+16)-\mathrm{Y}(\mathrm{tlt}+24)$ & -0.11 & 0.64 & -0.13 & -0.33 & -0.06 & -0.07 & -0.21 & -0.42 \\
\hline \multicolumn{9}{|c|}{ Standard deviation of the series } \\
\hline & 1.52 & 5.12 & 3.86 & 2.40 & 1.65 & 1.12 & 0.67 & 3.18 \\
\hline \multicolumn{9}{|c|}{ Standard deviation of revisions } \\
\hline $\mathrm{Y}(\mathrm{tlt}+4)-\mathrm{Y}(\mathrm{tlt}+24)$ & 0.27 & 3.44 & 0.74 & 1.16 & 0.53 & 0.79 & 0.73 & 1.44 \\
\hline $\mathrm{Y}(\mathrm{tlt}+6)-\mathrm{Y}(\mathrm{tlt}+24)$ & 0.21 & 3.05 & 0.62 & 1.01 & 0.54 & 0.70 & 0.50 & 1.42 \\
\hline $\mathrm{Y}(\mathrm{tlt}+8)-\mathrm{Y}(\mathrm{tlt}+24)$ & 0.21 & 2.89 & 0.51 & 1.01 & 0.48 & 0.69 & 0.50 & 1.05 \\
\hline $\mathrm{Y}(\mathrm{tt}+12)-\mathrm{Y}(\mathrm{tlt}+24)$ & 0.17 & 1.85 & 0.39 & 0.99 & 0.41 & 0.60 & 0.52 & 1.37 \\
\hline $\mathrm{Y}(\mathrm{tlt}+16)-\mathrm{Y}(\mathrm{tlt}+24)$ & 0.14 & 1.44 & 0.41 & 0.92 & 0.31 & 0.52 & 0.51 & 1.03 \\
\hline \multicolumn{9}{|c|}{ Constant prices quarter on quarter } \\
\hline \multicolumn{9}{|c|}{ Mean of the series } \\
\hline & 0.30 & -0.04 & -0.03 & 0.19 & 0.35 & 0.53 & 0.34 & 0.10 \\
\hline \multicolumn{9}{|c|}{ Mean of revisions } \\
\hline $\mathrm{Y}(\mathrm{tlt}+4)-\mathrm{Y}(\mathrm{tlt}+24)$ & -0.05 & 0.29 & -0.07 & -0.33 & -0.03 & -0.04 & -0.01 & -0.02 \\
\hline $\mathrm{Y}(\mathrm{tlt}+6)-\mathrm{Y}(\mathrm{tlt}+24)$ & -0.05 & 0.42 & -0.06 & -0.23 & 0.04 & -0.08 & -0.06 & 0.10 \\
\hline $\mathrm{Y}(\mathrm{tlt}+8)-\mathrm{Y}(\mathrm{tlt}+24)$ & -0.03 & 0.36 & -0.02 & -0.16 & 0.04 & -0.08 & -0.03 & 0.04 \\
\hline $\mathrm{Y}(\mathrm{tt}+12)-\mathrm{Y}(\mathrm{tlt}+24)$ & -0.01 & 0.19 & -0.01 & -0.10 & 0.03 & -0.04 & -0.03 & -0.01 \\
\hline$Y(t \mid t+16)-Y(t \mid t+24)$ & -0.01 & -0.21 & -0.03 & -0.06 & 0.09 & -0.02 & -0.03 & 0.04 \\
\hline \multicolumn{9}{|c|}{ Standard deviation of the series } \\
\hline & 0.69 & 2.41 & 1.97 & 1.12 & 0.80 & 0.49 & 0.15 & 1.05 \\
\hline \multicolumn{9}{|c|}{ Standard deviation of revisions } \\
\hline $\mathrm{Y}(\mathrm{tlt}+4)-\mathrm{Y}(\mathrm{t} t \mathrm{t}+24)$ & 0.11 & 1.52 & 0.39 & 0.75 & 0.41 & 0.33 & 0.27 & 0.79 \\
\hline $\mathrm{Y}(\mathrm{tlt}+6)-\mathrm{Y}(\mathrm{tlt}+24)$ & 0.10 & 1.42 & 0.35 & 0.48 & 0.35 & 0.25 & 0.25 & 0.51 \\
\hline $\mathrm{Y}(\mathrm{tlt}+8)-\mathrm{Y}(\mathrm{tlt}+24)$ & 0.09 & 1.37 & 0.34 & 0.46 & 0.30 & 0.25 & 0.23 & 0.57 \\
\hline $\mathrm{Y}(\mathrm{tlt}+12)-\mathrm{Y}(\mathrm{tlt}+24)$ & 0.09 & 1.44 & 0.25 & 0.44 & 0.28 & 0.23 & 0.22 & 0.51 \\
\hline $\mathrm{Y}(\mathrm{tlt}+16)-\mathrm{Y}(\mathrm{ttl}+24)$ & 0.06 & 1.05 & 0.17 & 0.35 & 0.26 & 0.22 & 0.23 & 0.44 \\
\hline
\end{tabular}

Sources: Eurostat and ECB calculations. 
2. Value added by economic activity (cont'd) (seasonally adjusted)

\begin{tabular}{|c|c|c|c|c|c|c|c|c|}
\hline & \multicolumn{7}{|c|}{ Gross value added (basic prices) } & \multirow{2}{*}{$\begin{array}{r}\text { Taxes less } \\
\text { subsidies on } \\
\text { products }\end{array}$} \\
\hline & Total & $\begin{array}{r}\text { Agriculture, } \\
\text { hunting, } \\
\text { forestry } \\
\text { and fishing } \\
\text { activities } \\
2\end{array}$ & $\begin{array}{r}\text { Mining, } \\
\text { manufacturing } \\
\text { and energy }\end{array}$ & Construction & $\begin{array}{r}\text { Trade, repairs, } \\
\text { hotels and } \\
\text { restaurants, } \\
\text { transport and } \\
\text { communication } \\
5\end{array}$ & $\begin{array}{r}\text { Financial, real } \\
\text { estate, renting } \\
\text { and business } \\
\text { activities }\end{array}$ & $\begin{array}{r}\text { Public } \\
\text { administration, } \\
\text { education, } \\
\text { health and } \\
\text { other services } \\
7\end{array}$ & \\
\hline \multicolumn{9}{|c|}{ Constant prices year on year } \\
\hline \multicolumn{9}{|c|}{ Mean of the series } \\
\hline & 1.74 & -0.22 & 1.33 & 0.99 & 1.99 & 2.46 & 1.41 & 0.89 \\
\hline \multicolumn{9}{|c|}{ Mean of revisions } \\
\hline $\mathrm{Y}(\mathrm{tt}+4)-\mathrm{Y}(\mathrm{t} t \mathrm{t}+24)$ & -0.14 & 0.58 & -0.12 & -0.89 & 0.04 & -0.24 & -0.09 & -0.27 \\
\hline $\mathrm{Y}(\mathrm{tlt}+6)-\mathrm{Y}(\mathrm{tlt}+24)$ & -0.12 & 0.24 & -0.10 & -0.64 & 0.11 & -0.24 & -0.13 & -0.22 \\
\hline $\mathrm{Y}(\mathrm{tt}+8)-\mathrm{Y}(\mathrm{tt}+24)$ & -0.09 & 0.02 & -0.05 & -0.56 & 0.17 & -0.27 & -0.05 & -0.27 \\
\hline $\mathrm{Y}(\mathrm{tlt}+12)-\mathrm{Y}(\mathrm{tlt}+24)$ & -0.07 & -0.32 & -0.08 & -0.31 & 0.08 & -0.15 & -0.04 & -0.15 \\
\hline $\mathrm{Y}(\mathrm{t} t \mathrm{t}+16)-\mathrm{Y}(\mathrm{tt}+24)$ & -0.06 & -0.61 & -0.05 & -0.17 & 0.04 & -0.11 & -0.03 & -0.03 \\
\hline \multicolumn{9}{|c|}{ Standard deviation of the series } \\
\hline & 1.59 & 5.49 & 3.84 & 2.17 & 1.82 & 1.23 & 0.26 & 1.87 \\
\hline \multicolumn{9}{|c|}{ Standard deviation of revisions } \\
\hline $\mathrm{Y}(\mathrm{t} t \mathrm{t}+4)-\mathrm{Y}(\mathrm{t} t \mathrm{t}+24)$ & 0.18 & 3.42 & 0.51 & 1.04 & 0.38 & 0.72 & 0.41 & 0.98 \\
\hline $\mathrm{Y}(\mathrm{tt}+6)-\mathrm{Y}(\mathrm{tlt}+24)$ & 0.19 & 2.98 & 0.42 & 0.94 & 0.52 & 0.60 & 0.41 & 0.92 \\
\hline $\mathrm{Y}(\mathrm{tlt}+8)-\mathrm{Y}(\mathrm{tlt}+24)$ & 0.18 & 2.73 & 0.43 & 0.99 & 0.49 & 0.64 & 0.40 & 0.92 \\
\hline $\mathrm{Y}(\mathrm{tlt}+12)-\mathrm{Y}(\mathrm{tlt}+24)$ & 0.16 & 1.91 & 0.47 & 0.95 & 0.32 & 0.60 & 0.41 & 0.98 \\
\hline $\mathrm{Y}(\mathrm{tlt}+16)-\mathrm{Y}(\mathrm{tlt}+24)$ & 0.11 & 1.69 & 0.46 & 0.89 & 0.31 & 0.53 & 0.47 & 0.89 \\
\hline \multicolumn{9}{|c|}{ Publication lag (months) } \\
\hline & 2 & 2 & 2 & 2 & 2 & 2 & 2 & 2 \\
\hline
\end{tabular}

Sources: Eurostat and ECB calculations. 
T2 Output and demand

(annual percentage changes, unless otherwise indicated)

3. Industrial production

\begin{tabular}{|c|c|c|c|c|c|c|c|c|c|c|c|}
\hline & \multirow{4}{*}{$\begin{array}{r}\text { Total } \\
\\
\\
1\end{array}$} & \multicolumn{9}{|c|}{ Industry excluding construction } & \multirow{4}{*}{$\begin{array}{l}\text { Construction } \\
\\
11\end{array}$} \\
\hline & & \multicolumn{2}{|c|}{ Total } & \multicolumn{6}{|c|}{ Industry excluding construction and energy } & \multirow{3}{*}{$\begin{array}{r}\text { Energy } \\
\\
\\
10\end{array}$} & \\
\hline & & \multirow[b]{2}{*}{2} & \multirow{2}{*}{$\begin{array}{r}\begin{array}{r}\text { Manu- } \\
\text { facturing }\end{array} \\
3\end{array}$} & \multirow{2}{*}{$\begin{array}{r}\text { Total } \\
4 \\
4\end{array}$} & \multirow{2}{*}{$\begin{array}{r}\text { Intermediate } \\
\text { goods } \\
\\
5 \\
\end{array}$} & \multirow{2}{*}{\begin{tabular}{r|r}
$\begin{array}{r}\text { Capital } \\
\text { goods }\end{array}$ \\
\\
6 \\
\end{tabular}} & \multicolumn{3}{|c|}{ Consumer goods } & & \\
\hline & & & & & & & $\begin{array}{r}\text { Total } \\
7\end{array}$ & $\begin{array}{r}\text { Durable } \\
8\end{array}$ & $\begin{array}{r}\text { Non-durable } \\
9\end{array}$ & & \\
\hline \multicolumn{12}{|c|}{ Mean of the series } \\
\hline & 0.64 & 0.73 & 0.73 & 0.57 & 0.20 & 1.51 & 0.36 & -1.92 & 0.75 & 1.04 & 0.70 \\
\hline \multicolumn{12}{|c|}{ Mean of revisions } \\
\hline $\mathrm{Y}(\mathrm{tlt}+4)-\mathrm{Y}(\mathrm{t} t \mathrm{t}+24)$ & -0.48 & -0.23 & -0.22 & -0.23 & -0.14 & -0.51 & -0.22 & -0.08 & -0.24 & -0.05 & -1.34 \\
\hline $\mathrm{Y}(\mathrm{tlt}+6)-\mathrm{Y}(\mathrm{tlt}+24)$ & -0.26 & -0.16 & -0.14 & -0.16 & -0.14 & -0.37 & -0.10 & 0.01 & -0.12 & -0.06 & -0.61 \\
\hline $\mathrm{Y}(\mathrm{t} t \mathrm{t}+8)-\mathrm{Y}(\mathrm{t} \mid \mathrm{t}+24)$ & -0.23 & -0.12 & -0.10 & -0.12 & -0.09 & -0.31 & -0.10 & 0.03 & -0.11 & -0.05 & -0.42 \\
\hline$Y(t \mid t+12)-Y(t \mid t+24)$ & -0.14 & -0.08 & -0.07 & -0.10 & -0.09 & -0.29 & -0.09 & 0.01 & -0.09 & 0.01 & -0.22 \\
\hline$Y(t \mid t+16)-Y(t t t+24)$ & -0.10 & -0.07 & -0.07 & -0.06 & -0.08 & -0.20 & -0.06 & 0.00 & -0.06 & 0.06 & -0.11 \\
\hline \multicolumn{12}{|c|}{ Standard deviation of the series } \\
\hline & 4.15 & 4.39 & 4.48 & 5.03 & 6.04 & 6.12 & 2.84 & 5.58 & 2.51 & 3.41 & 3.46 \\
\hline \multicolumn{12}{|c|}{ Standard deviation of revisions } \\
\hline$Y(t \mid t+4)-Y(t \mid t+24)$ & 0.70 & 0.41 & 0.36 & 0.48 & 0.60 & 0.79 & 0.62 & 0.88 & 0.72 & 0.93 & 2.86 \\
\hline$Y(t \mid t+6)-Y(t \mid t+24)$ & 0.62 & 0.40 & 0.36 & 0.47 & 0.54 & 0.74 & 0.59 & 0.85 & 0.65 & 0.69 & 1.67 \\
\hline$Y(t \mid t+8)-Y(t \mid t+24)$ & 0.49 & 0.37 & 0.32 & 0.38 & 0.49 & 0.61 & 0.44 & 0.74 & 0.49 & 0.66 & 1.14 \\
\hline$Y(t \mid t+12)-Y(t \mid t+24)$ & 0.40 & 0.29 & 0.22 & 0.34 & 0.39 & 0.52 & 0.34 & 0.61 & 0.39 & 0.55 & 0.72 \\
\hline$Y(t \mid t+16)-Y(t \mid t+24)$ & 0.35 & 0.20 & 0.20 & 0.29 & 0.29 & 0.41 & 0.29 & 0.49 & 0.32 & 0.36 & 0.42 \\
\hline \multicolumn{12}{|c|}{ Publication lag (months) } \\
\hline & 2 & 2 & 2 & 2 & 2 & 2 & 2 & 2 & 2 & 2 & 2 \\
\hline
\end{tabular}

Sources: Eurostat and ECB calculations. 
T2 Output and demand

(annual percentage changes, unless otherwise indicated)

4. Retail sales and new passenger car registrations

(seasonally adjusted, unless otherwise indicated)

\begin{tabular}{|c|c|c|c|c|c|c|c|c|}
\hline & \multicolumn{6}{|c|}{ Retail sales } & \multirow{2}{*}{\multicolumn{2}{|c|}{$\begin{array}{l}\text { New passenger car } \\
\text { registrations }\end{array}$}} \\
\hline & \multirow{3}{*}{\begin{tabular}{r|} 
Current prices \\
Total
\end{tabular}} & \multicolumn{5}{|c|}{ Constant prices } & & \\
\hline & & Total & & & on-food & & \multirow[t]{2}{*}{ Total } & \multirow[t]{2}{*}{ Total (n.s.a) } \\
\hline & & 2 & tobacco & 4 & $\begin{array}{r}\text { Textiles, } \\
\text { clothing, } \\
\text { footwear } \\
5\end{array}$ & $\begin{array}{r}\begin{array}{r}\text { Household } \\
\text { equipment }\end{array} \\
6\end{array}$ & & \\
\hline \multicolumn{9}{|c|}{ Mean of the series } \\
\hline & 2.61 & 0.99 & 0.58 & 1.17 & 1.05 & 1.09 & -1.50 & -1.49 \\
\hline \multicolumn{9}{|c|}{ Mean of revisions } \\
\hline $\mathrm{Y}(\mathrm{tlt}+4)-\mathrm{Y}(\mathrm{t} t \mathrm{t}+24)$ & -0.34 & -0.25 & -0.25 & -0.29 & -0.20 & -0.35 & -0.46 & -0.57 \\
\hline $\mathrm{Y}(\mathrm{tlt}+6)-\mathrm{Y}(\mathrm{tt}+24)$ & -0.29 & -0.19 & -0.24 & -0.24 & -0.23 & -0.33 & -0.40 & -0.56 \\
\hline $\mathrm{Y}(\mathrm{t} \mid \mathrm{t}+8)-\mathrm{Y}(\mathrm{t} \mid \mathrm{t}+24)$ & -0.23 & -0.14 & -0.20 & -0.17 & -0.19 & -0.26 & -0.34 & -0.57 \\
\hline $\mathrm{Y}(\mathrm{tlt}+12)-\mathrm{Y}(\mathrm{tt}+24)$ & -0.11 & -0.09 & -0.10 & -0.10 & -0.10 & -0.16 & -0.21 & -0.51 \\
\hline $\mathrm{Y}(\mathrm{tlt}+16)-\mathrm{Y}(\mathrm{tlt}+24)$ & 0.02 & 0.01 & -0.01 & -0.03 & 0.02 & -0.01 & 0.02 & -0.24 \\
\hline \multicolumn{9}{|c|}{ Standard deviation of the series } \\
\hline & 1.07 & 1.20 & 1.39 & 1.46 & 3.04 & 2.49 & 5.54 & 5.80 \\
\hline \multicolumn{9}{|c|}{ Standard deviation of revisions } \\
\hline $\mathrm{Y}(\mathrm{tt}+4)-\mathrm{Y}(\mathrm{t} t \mathrm{t}+24)$ & 0.68 & 0.78 & 0.78 & 0.82 & 1.49 & 0.93 & 1.18 & 1.13 \\
\hline $\mathrm{Y}(\mathrm{tt}+6)-\mathrm{Y}(\mathrm{tt}+24)$ & 0.61 & 0.74 & 0.75 & 0.79 & 1.40 & 0.85 & 1.09 & 1.13 \\
\hline $\mathrm{Y}(\mathrm{t} \mid \mathrm{t}+8)-\mathrm{Y}(\mathrm{tlt}+24)$ & 0.62 & 0.69 & 0.74 & 0.70 & 1.29 & 0.75 & 1.05 & 1.16 \\
\hline $\mathrm{Y}(\mathrm{tlt}+12)-\mathrm{Y}(\mathrm{tlt}+24)$ & 0.55 & 0.62 & 0.69 & 0.67 & 1.12 & 0.68 & 1.08 & 1.20 \\
\hline $\mathrm{Y}(\mathrm{t} \mid \mathrm{t}+16)-\mathrm{Y}(\mathrm{t} \mid \mathrm{t}+24)$ & 0.41 & 0.43 & 0.46 & 0.47 & 0.85 & 0.50 & 0.81 & 1.15 \\
\hline \multicolumn{9}{|c|}{ Publication lag (months) } \\
\hline & 1 & 1 & 1 & 1 & 2 & 2 & 1 & 1 \\
\hline
\end{tabular}

Sources: Eurostat and ECB calculations. 
T2 Output and demand

(percentage balances, ${ }^{1)}$ unless otherwise indicated; seasonally adjusted)

5. Business and Consumer Surveys

\begin{tabular}{|c|c|c|c|c|c|c|c|c|c|c|c|}
\hline & \multirow{3}{*}{$\begin{array}{r}\text { Economic } \\
\text { sentiment } \\
\text { indicator } \\
\text { (long-term } \\
\text { average } \\
=100 \text { ) } \\
1 \\
1\end{array}$} & \multicolumn{5}{|c|}{ Manufacturing industry } & \multicolumn{5}{|c|}{ Consumer confidence indicator } \\
\hline & & \multicolumn{4}{|c|}{ Industrial confidence indicator } & \multirow{2}{*}{$\begin{array}{r}\text { Capacity } \\
\text { utilisation } \\
\text { (percentages) }\end{array}$} & \multirow[t]{2}{*}{ Total } & \multirow{2}{*}{ 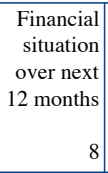 } & \multirow{2}{*}{$\begin{array}{r}\text { Economic } \\
\text { situation } \\
\text { over next } \\
12 \text { months } \\
9\end{array}$} & \multirow{2}{*}{\begin{tabular}{|r|} 
Unemployment \\
situation \\
over next \\
12 months \\
\\
10
\end{tabular}} & \multirow{2}{*}{$\begin{array}{r}\text { Saving } \\
\text { over nex } \\
12 \text { month } \\
1\end{array}$} \\
\hline & & Total & $\begin{array}{r}\begin{array}{r}\text { Order } \\
\text { books }\end{array} \\
3\end{array}$ & $\begin{array}{r}\text { Stocks of } \\
\text { finished } \\
\text { products } \\
4\end{array}$ & $\begin{array}{r}\text { Production } \\
\text { expectations }\end{array}$ & & & & & & \\
\hline \multicolumn{12}{|c|}{ Mean of the series } \\
\hline & 97.88 & -6.71 & -15.09 & 9.74 & 4.72 & 81.68 & -12.46 & -3.71 & -14.60 & 23.50 & -8.05 \\
\hline \multicolumn{12}{|c|}{ Mean of revisions } \\
\hline$Y(t \mathrm{tl}+4)-\mathrm{Y}(\mathrm{ttl}+24)$ & 1.74 & 0.19 & 0.23 & 0.09 & 0.25 & -0.08 & -0.05 & 0.15 & 0.18 & -0.11 & 0.18 \\
\hline $\mathrm{Y}(\mathrm{ttl}+6)-\mathrm{Y}(\mathrm{ttl}+24)$ & 1.65 & 0.14 & 0.22 & 0.05 & 0.14 & -0.06 & 0.02 & 0.14 & 0.17 & -0.13 & 0.15 \\
\hline $\mathrm{Y}(\mathrm{t} t+8)-\mathrm{Y}(\mathrm{t} \mid \mathrm{t}+24)$ & 1.56 & 0.17 & 0.19 & 0.00 & 0.18 & -0.04 & 0.07 & 0.12 & 0.17 & -0.10 & 0.09 \\
\hline $\mathrm{Y}(\mathrm{tt}+12)-\mathrm{Y}(\mathrm{tlt}+24)$ & 1.18 & 0.15 & 0.16 & 0.00 & 0.13 & 0.00 & 0.05 & 0.10 & 0.08 & -0.02 & 0.04 \\
\hline $\mathrm{Y}(\mathrm{t} t \mathrm{t}+16)-\mathrm{Y}(\mathrm{tt}+24)$ & 0.70 & 0.12 & 0.12 & -0.01 & 0.13 & 0.02 & 0.02 & 0.08 & 0.02 & 0.04 & 0.02 \\
\hline \multicolumn{12}{|c|}{ Standard deviation of the series } \\
\hline & 10.47 & 9.54 & 15.28 & 4.04 & 10.51 & 2.67 & 7.29 & 3.75 & 9.28 & 15.15 & 4.52 \\
\hline \multicolumn{12}{|c|}{ Standard deviation of revisions } \\
\hline $\mathrm{Y}(\mathrm{t} t \mathrm{t}+4)-\mathrm{Y}(\mathrm{t} \mid \mathrm{t}+24)$ & 2.46 & 0.74 & 0.83 & 0.44 & 1.31 & 0.22 & 0.77 & 0.31 & 0.45 & 0.51 & 0.86 \\
\hline $\mathrm{Y}(\mathrm{tlt}+6)-\mathrm{Y}(\mathrm{ttl}+24)$ & 2.23 & 0.70 & 0.84 & 0.50 & 1.23 & 0.21 & 0.68 & 0.30 & 0.45 & 0.51 & 0.80 \\
\hline $\mathrm{Y}(\mathrm{ttl}+8)-\mathrm{Y}(\mathrm{tt}+24)$ & 1.98 & 0.67 & 0.81 & 0.43 & 1.17 & 0.18 & 0.45 & 0.28 & 0.45 & 0.47 & 0.78 \\
\hline $\mathrm{Y}(\mathrm{tlt}+12)-\mathrm{Y}(\mathrm{tlt}+24)$ & 1.61 & 0.64 & 0.76 & 0.41 & 1.00 & 0.14 & 0.23 & 0.24 & 0.32 & 0.38 & 0.72 \\
\hline$Y(t \mid t+16)-Y(t \mid t+24)$ & 1.27 & 0.49 & 0.58 & 0.28 & 0.76 & 0.16 & 0.19 & 0.21 & 0.22 & 0.27 & 0.62 \\
\hline \multicolumn{12}{|c|}{ Publication lag (months) } \\
\hline & 0 & 0 & 0 & 0 & 0 & 0 & 0 & 0 & 0 & 0 & 0 \\
\hline
\end{tabular}

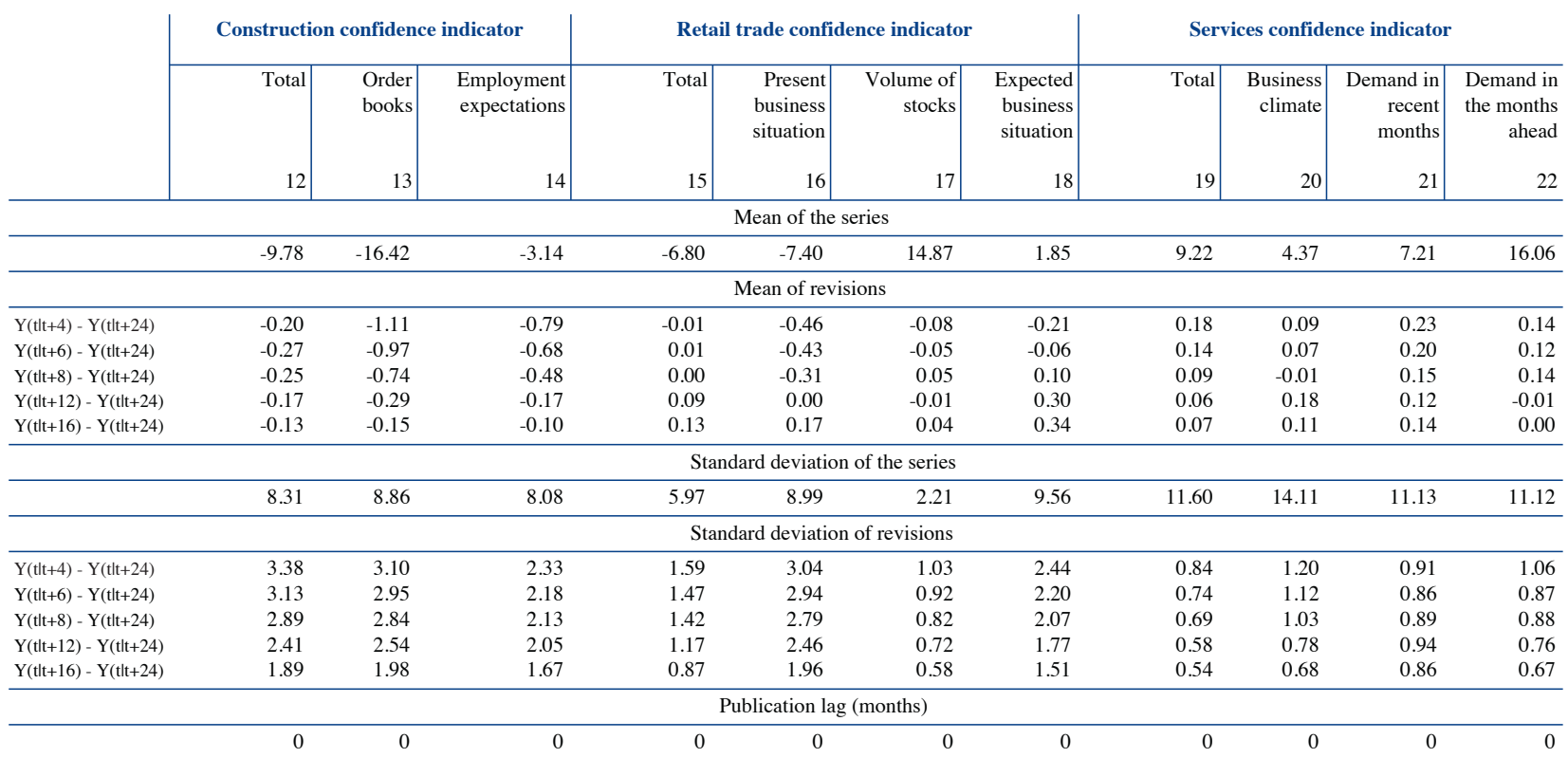

Source: European Commission (Economic and Financial Affairs DG) and ECB calculations. 
